\title{
How Do Households Allocate Their Assets? Stylized Facts from the Eurosystem Household Finance and Consumption Survey*
}

\author{
Luc Arrondel, ${ }^{\mathrm{a}}$ Laura Bartiloro, ${ }^{\mathrm{b}}$ Pirmin Fessler, ${ }^{\mathrm{c}}$ \\ Peter Lindner, ${ }^{\mathrm{c}}$ Thomas Y. Mathä, ${ }^{\mathrm{d}}$ Cristiana Rampazzi, ${ }^{\mathrm{b}}$ \\ Frédérique Savignac, ${ }^{\mathrm{e}}$ Tobias Schmidt, ${ }^{\mathrm{f}}$ Martin Schürz, ${ }^{\mathrm{c}}$ \\ and Philip Vermeulen ${ }^{\mathrm{g}}$ \\ ${ }^{a}$ CNRS-PSE and Banque de France \\ ${ }^{b}$ Banca d'Italia \\ ${ }^{\mathrm{c}}$ Oesterreichische Nationalbank \\ ${ }^{\mathrm{d} B a n q u e}$ centrale du Luxembourg \\ ${ }^{\mathrm{e}}$ Banque de France \\ ${ }^{\mathrm{f}}$ Deutsche Bundesbank \\ ${ }^{g}$ European Central Bank
}

\begin{abstract}
Using the first wave of the Eurosystem Household Finance and Consumption Survey (HFCS), a large micro-level data set on households' balance sheets in fifteen euro-area countries, this paper explores how households allocate their assets. We derive stylized facts on asset participation as well as the
\end{abstract}

*This paper should not be reported as representing the views of the Banca d'Italia, Banque de France, Banque centrale du Luxembourg, Deutsche Bundesbank, Oesterreichische Nationalbank, European Central Bank, the Eurosystem, or any other institution the authors are affiliated with. The views expressed are those of the authors and may not be shared by other research staff or policymakers in the Banca d'Italia, Banque de France, Banque centrale du Luxembourg, Deutsche Bundesbank, Oesterreichische Nationalbank, European Central Bank, or the Eurosystem. Any remaining errors are the authors' own responsibility. We would like to thank Richard Blundell, Michael Haliassos, Jirka Slacalek, Gabriel Fagan, John Campbell, and the participants of the Royal Economic Society Annual conference in April 2013 and the HFCN conference in October 2013 for their valuable comments. We also thank Sylvie Tarrieu for her excellent research assistance. Author e-mails: arrondel@pse.ens.fr; laura.bartiloro@ bancaditalia.it; pirmin.fessler@oenb.at; peter.lindner@oenb.at; thomas.mathae@ bcl.lu; cristiana.rampazzi@bancaditalia.it; frederique.savignac@banque-france.fr; tobias.schmidt@bundesbank.de; martin.schuerz@oenb.at; philip.vermeulen@ecb. europa.eu. 
portfolio shares of asset holdings and investigate the systematic relationships between household characteristics and asset holding patterns. Real assets make up the bulk of total assets. Whereas ownership of the main residence varies strongly between countries, the value of the main residence tends to be the major asset for homeowners and represents a significant part of total assets in all countries. While almost all households hold safe financial assets, a low share of households holds risky assets. The ownership rates of all asset categories generally increase with wealth (and income). The significance of inheritances for homeownership and holding of other real estate is remarkable. We tentatively link differences in asset holding patterns across countries to differences in institutions.

JEL Codes: D1, D3.

\section{Introduction}

How do households choose to allocate their wealth across available assets? Is there a systematic relationship between underlying household characteristics and asset holding patterns across countries? This paper uses a large data set containing comparable household micro data from fifteen euro-area countries to shed light on these researchand policy-relevant questions.

Recent findings in the household finance literature have emphasized that asset holdings are heterogeneous across households and across countries (see Guiso, Haliassos, and Jappelli 2002, 2003; Sierminska and Doorley 2012, and Christelis, Georgarakos, and Haliassos 2013). Extending the existing literature, this paper documents differences in asset participation and holdings across a broad range of assets for fifteen euro-area countries in a data set consisting of ex ante comparable country surveys representative of the respective total population.

Our analysis is based on the Eurosystem Household Finance and Consumption Survey (Household Finance and Consumption Network 2013a), which provides detailed household-level information on wealth, assets, and debt holding, income, as well as on the household composition for fifteen euro-area countries. We study the determinants of both asset holdings (extensive margin) and the portfolio share invested in each asset by households (intensive margin). 
The main components of household wealth considered are housing assets (decomposed into household main residence and other real estate), risky financial assets (mutual funds, bonds, and shares), safe financial assets (defined as deposits, life insurance contracts, and voluntary private pension plans), and business wealth (defined as self-employment participation).

We first document participation rates and portfolio shares (conditional on participation) in these asset categories across wealth quintiles and across euro-area countries. We confirm the standard finding that wealthier households tend to participate in a wider range of asset categories. However, we uncover substantial differences across countries - in particular, for housing wealth.

In a second step, we analyze the household-level determinants of asset participation and of the portfolio shares by estimating, respectively, probit and tobit models. We find considerable overlap in the factors that determine asset participation choices and the portfolio shares invested. We find that a number of household characteristics are robust predictors of household portfolio choices in the sense that, in a majority of countries, their estimated marginal effects are statistically significant and have the same sign, even though their estimated sizes may differ. This points not only to the importance of such factors but also to the conclusion that the variation in institutional, policy, and other environmental factors within the euro area does not seem to reverse or render insignificant the importance of such underlying household characteristics.

Nevertheless, differences remain across countries in the measured effects of demographic variables. Identifying the potential sources explaining those differences is not an easy task. Many factorsincluding culture, history, welfare state, housing and credit markets, and financial institutions - are likely to affect the wealth accumulation process and portfolio choices of households. To this end, we examine the correlations between the estimated marginal effects of key sociodemographic explanatory variables and selected institutional factors. We find some evidence that suggests the strength of the influence of the sociodemographic factors on the choice of holding real and risky financial assets to be correlated with the institutional framework in a given country.

A brief literature review (section 2) introduces the topic of household portfolio choices and the issues that have evolved in this 
field. After presenting the data and the first descriptive analysis of assets composition in section 3, we analyze extensive margins using probit regressions for different asset categories and countries (in section 4). Furthermore, we present results on the intensive margins using tobit regressions (also in section 4). Section 5 investigates the role of institutions as factors altering the impact of certain household characteristics on portfolio choice. Section 6 concludes the paper.

\section{International Differences in Asset Holding Behavior}

\subsection{Existing Research}

The first cross-country comparisons of wealth and portfolio choice behavior at the household level on a relatively large scale were provided by Guiso, Haliassos, and Jappelli (2002, 2003). They find substantial differences in stock market participation between major European countries (France, Germany, Italy, the Netherlands, Sweden, and the United Kingdom) and the United States. They also emphasize some regular empirical facts, such as the positive correlation of stockholding with education. More recently, Christelis, Georgarakos, and Haliassos (2013) use SHARE, ELSA, and HRS micro data 1 to document international differences in ownership and holdings of stocks, private businesses, homes, and mortgages among households in the fifty-plus age group in thirteen countries (the United States, the United Kingdom, and eleven continental European countries). They find that households with given characteristics have different probabilities of participating in a given asset category both across the Atlantic and within Europe. U.S. households tend to invest more in stocks and less in homes and tend to have larger mortgages than European households with similar characteristics. Based on counterfactual analysis, they show that these

\footnotetext{
${ }^{1}$ SHARE (Survey of Health, Ageing and Retirement in Europe) is a major survey with standardized information on household behavior, including wealth and portfolio composition. It also includes the ELSA (English Longitudinal Study of Ageing) survey for England and HRS (Heath and Retirement Study) data for the United States. As it focuses on retirement and aging issues, it includes only individuals over fifty years of age and does not provide any information for the rest of the population.
} 
differences in ownership and amounts are primarily linked to differences in economic environments (i.e., institutional factors) rather than related to population characteristics. Furthermore, reported differences seem to be even more pronounced among European countries than among U.S. regions, which according to Christelis, Georgarakos, and Haliassos (2013) suggests potential for more harmonization. From the point of view of this paper, their finding suggests a higher potential for testing the relevance of each household characteristic across euro-area countries than across U.S. regions and more importance of robust effects of any given factor across euro-area countries.

Sierminska and Doorley (2012) extend the Christelis, Georgarakos, and Haliassos (2013) approach in the direction of studying survey data that is representative of the entire population. They use the ex post harmonized data set from the Luxembourg Wealth Study (LWS) to analyze household portfolios for the whole population in five countries (United States, Germany, Italy, Luxembourg, and Spain). Concerning cross-country differences in asset participation, their results confirm the limited role of demographic characteristics for households in the fifty-plus age group, and they also reveal a stronger role of observable demographic characteristics for younger households. They find that the household characteristics helping to explain the amount of assets held change along the wealth distribution. It seems that they do better in explaining the existing cross-country differences in the middle than in the tails of the wealth distribution. All in all, they conclude that institutional and nonobserved characteristics are more likely to influence cross-country differences for old and wealthy households.

\subsection{Asset Holdings in the Euro Area}

Our data is taken from the Eurosystem HFCS2 The net sample of the survey includes 62,521 households from Belgium (BE), Germany (DE), Greece (GR), Spain (ES), France (FR), Italy (IT), Cyprus (CY), Luxembourg (LU), Malta (MT), the Netherlands (NL), Austria (AT), Portugal (PT), Slovenia (SI), Slovakia (SK),

\footnotetext{
${ }^{2}$ Here, we only briefly summarize the most basic information regarding the survey. For more details, see HFCN (2013a, 2013b).
} 
and Finland (FI) 3 The survey was conducted in each country separately under common guidelines. Households were interviewed in 2010/11 with the exception of France (2009/10), Spain (2008/9), and Greece (2009). They thus provide a snapshot of a single point in time. The reference period for most of the information on wealth is the time of the interview. In particular, when comparing the values of the asset holdings across countries, the differences in the reference years must be kept in mind 4 Notwithstanding this, our focus is more on structural determinants of asset holdings, which should fluctuate less over time. The HFCS contains detailed information on asset holdings. We distinguish the following asset categories:

- Household main residence (HMR): owner-occupied housing

- Other real estate (ORE): real estate other than the main residence (including holiday homes/apartments, commercially used real estate, and land)

- Self-employed businesses (BUS): market value of all business assets including property and intangibles minus value of liabilities (net value concept)

- Safe financial assets (SAFE): deposits (sight and savings accounts), life insurance contracts, and voluntary private pension plans

- Risky financial asset5 (RISKY): mutual funds, bonds (including public bonds for which the degree of risk is lower), and shares

In the next sections, we document households' wealth composition for each of the fifteen euro-area countries. More specifically, for each of the outlined asset categories, we provide the participation rates (extensive margin) and the median values of the portfolio shares

\footnotetext{
${ }^{3}$ The remaining euro-area countries - Estonia, Ireland, and Latvia - did not take part in the first wave of the HFCS.

${ }^{4}$ Although differences in the valuation of real estate are acknowledged, internal calculations by the European Central Bank (ECB) adjusting for price variations show only small variation in the results. Hence in this analysis, we refrain from any adjustment of the collected data.

${ }^{5}$ The separation of safe and risky financial assets is along the lines laid out in Guiso, Jappelli, and Terlizzese (1996), who include long-term government bonds as well as corporate bonds in the category of risky financial assets.
} 
(conditional on participation) (intensive margin) and explore their variations along the wealth distribution 6

\section{Descriptive Results}

\subsection{The Distribution of Net Wealth in the Euro Area}

Before looking at the household wealth composition, table 1 provides an overview of the distribution of household net wealth within and across countries. Net wealth values, defined as real and financial assets minus liabilities, differ substantially within and across euroarea countries. This fact holds for all parts of the wealth distribution. For example, the households' median net wealth is around €109,000 for the euro area as a whole, and it ranges from roughly $€ 51,000$ in Germany to €398,000 in Luxembourg.

Common across countries, the distribution of net wealth is very unequal and highly skewed to the right, as illustrated by the difference between the median and the mean values. This concentration of wealth at the top end of the wealth distribution is a well-documented fact (see, for instance, Davies and Shorrocks 1999; Campbell 2006) and is also confirmed by our data across fifteen euro-area countries. In the euro area, 50 percent of households below or just at the median level hold only 12 percent of the net wealth, while the top decile holds 50 percent of net wealth.

\subsection{The Composition of Total Assets}

Household portfolios consist of self-assessed real assets and financial assets. Taking all fifteen countries together, the share of the household main residence in total gross assets is about 51 percent. This means that households in the euro area hold the majority of

\footnotetext{
${ }^{6}$ The estimations of the results below are based on all five implicates of the multiple imputed data provided in the Eurosystem HFCS. That means that the estimations are done for each implicate separately and then combined using Rubin's rule. All the estimations - including probit and tobit models - are done using the final household weights in order to take the survey design of the underlying data into account. For the calculation of the standard errors in the multivariate analysis, a bootstrap procedure using replicate weights, which are also provided in the HFCS, is applied. Standard errors presented below are based on the first 100 replicate weights in the data set.
} 


\section{Table 1. Descriptive Statistics of Net Wealth (EUR thousands)}

\begin{tabular}{|l|r|r|r|r|r|}
\hline & Obs. & Median & Mean & P5 & \multicolumn{1}{|c|}{ P95 } \\
\hline Euro Area & 62,521 & 109.2 & 230.8 & 0.0 & 762.1 \\
Austria & 2,380 & 76.4 & 265.0 & -0.2 & 934.6 \\
Belgium & 2,327 & 206.2 & 338.6 & 0.3 & $1,073.4$ \\
Cyprus & 1,237 & 266.9 & 670.9 & 0.0 & $2,411.9$ \\
Germany & 3,565 & 51.4 & 195.2 & -1.6 & 661.2 \\
Spain & 6,197 & 182.7 & 291.4 & 0.2 & 878.5 \\
Finland & 10,989 & 85.8 & 161.5 & -8.4 & 553.6 \\
France & 15,006 & 115.8 & 233.4 & 0.4 & 775.4 \\
Greece & 2,971 & 101.9 & 147.8 & 0.0 & 469.3 \\
Italy & 7,951 & 173.5 & 275.2 & 1.0 & 855.0 \\
Luxembourg & 950 & 397.8 & 710.1 & 0.1 & $2,023.9$ \\
Malta & 843 & 215.9 & 366.0 & 4.0 & $1,049.4$ \\
Netherlands & 1,301 & 103.6 & 170.2 & -34.6 & 581.2 \\
Portugal & 4,404 & 75.2 & 152.9 & 0.1 & 482.4 \\
Slovenia & 343 & 100.7 & 148.7 & 0.3 & 434.5 \\
Slovakia & 2,057 & 61.2 & 79.7 & 1.5 & 207.4 \\
\hline Source: HFCS 2013. & apart from the number of observations-are given in thousands \\
Notes: Estimates- & \multicolumn{5}{l}{ of euros. }
\end{tabular}

their wealth in the form of their main residence (see figure 1) 7 Country figures range from 41 percent in Germany to 61 percent in Italy and the Netherlands. All other asset categories account for substantially smaller shares of gross wealth. The share of risky financial assets (4 percent), i.e., the least important category in average terms, ranges from about 1 percent for Cyprus and Slovenia to 11 percent for Belgium. There is also considerable cross-country variation; e.g., while, in the Netherlands, 22 percent of gross wealth is held in safe financial assets, this asset category only represents

\footnotetext{
${ }^{7}$ The figures reported here are calculated by dividing the total value of all assets of a specific type by the total gross value of all assets. This is a different approach compared with calculating the share of an asset type in the portfolio of each household and then averaging across households.
} 


\section{Figure 1. Shares of Asset Categories Relative to Gross Wealth}

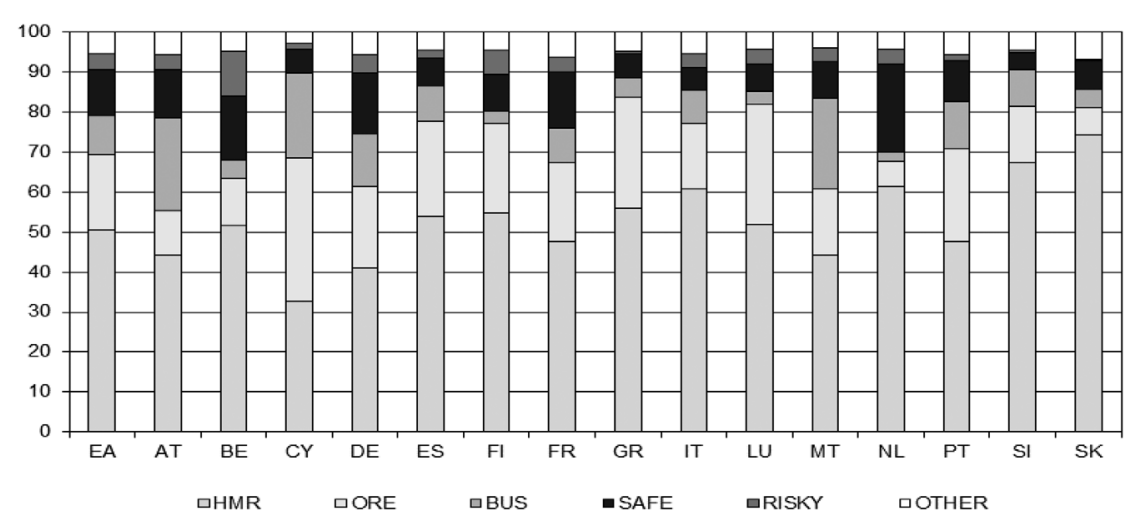

Source: HFCS 2013.

Notes: HMR: household's main residence, ORE: other real estate, BUS: selfemployment business, SAFE: safe financial assets, RISKY: risky financial assets, OTHER: other real assets (e.g., vehicles) and other financial assets (e.g., money owed to the households, money held in managed accounts). In Finland, information on BUS is only collected in a summary way; estimates are not comparable.

6 percent and 4 percent of gross wealth in Italy and Slovenia, respectively 8

These differences in the aggregate wealth composition reflect differences both in the extensive margin (the percentage of households owning a particular asset) and in the intensive margin (the portfolio share of this particular asset held by the household) 9

In addition to these variations in the composition of household wealth across countries, differences in the composition are also observed along the wealth distribution within countries. In particular, the existing empirical literature shows that the portfolio breadth increases with wealth. We contribute to this literature by comparing the participation rates and median values of asset categories along the net wealth distribution for each of the fifteen

\footnotetext{
${ }^{8}$ For safe assets a large part of the heterogeneity may be related to the different role of public pension schemes: where the latter are predominant, voluntary private pension plans are less relevant.

${ }^{9}$ The figures for the extensive (participation rate) and intensive margin (conditional median) are given in appendix 1 (see tables 14 and 15).
} 
euro-area countries. This confirms the larger variety of assets held as wealth increases and reveals moreover some interesting cross-country differences.

\subsubsection{Real Assets over the Net Wealth Distribution}

Real assets represent the predominant asset category, accounting for 85 percent of total gross assets on average (HFCN 2013b). And among real assets, the HMR is the most important asset category. Tables 2 and 3 show the share of households owning their main residence and other real estate broken down by quintiles of the net wealth distribution. In the euro area as a whole, 60 percent of households own their main residence and 24 percent own other real estate. As expected, the percentage of households owning either their household main residence (table 2) or other real estate (table 3) increases with net wealth. For the HMR, the participation rate reaches more than 90 percent in the fifth net wealth quintile for every country. However, there are pronounced differences between countries in the lower half of the wealth distribution. Participation is already above 90 percent in the second quintile in Spain; it stays below 10 percent in Austria and Germany and below 15 percent in France.

The conditional portfolio share of the HMR is a high 79 percent in the euro area. The share remains high along the first four quintiles of the net wealth distribution in every country. It falls in the last quintile. However, even in this fifth quintile the average homeowning household has more than 50 percent of its total gross wealth invested in its HMR (i.e., a portfolio share of 55 percent). The conditional portfolio share of other real estate in the euro area is 31 percent. Along the wealth distribution in most countries it is somewhat U-shaped, with portfolio shares that are somewhat higher in the first and fifth quintile than the middle quintiles.

Eleven percent of euro-area households hold business wealth (see table 4); the participation rate also clearly increases with net wealth. In particular, in the top 5 percent of the net wealth distribution almost 50 percent of the households in the euro area hold business wealth, whereas in the first four wealth quintiles ownership is restricted to a maximum of 10 percent of the households (only 2 percent of the households in the first quintile own a business). The pattern of ownership is relatively similar across countries with the 
Vol. 12 No. 2 How Do Households Allocate Their Assets?

\begin{tabular}{|c|c|c|c|c|c|}
\hline \multirow{7}{*}{ 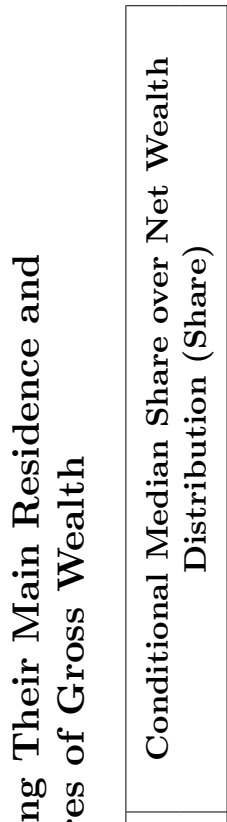 } & \multirow{7}{*}{ 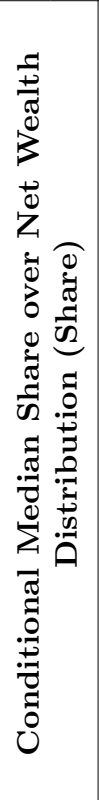 } & \multirow{7}{*}{ 总 } & $\begin{array}{l}\text { Do } \\
10 \\
20 \\
0 \\
\text { E⿱ }\end{array}$ & 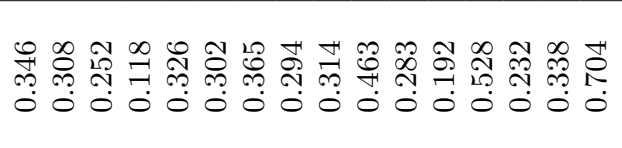 & \\
\hline & & & 兵 & 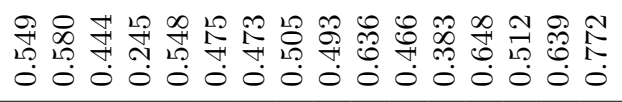 & \\
\hline & & & 秊 & 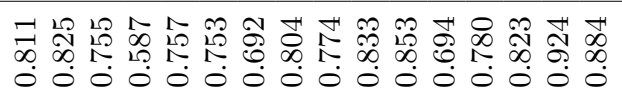 & \\
\hline & & & "ై & 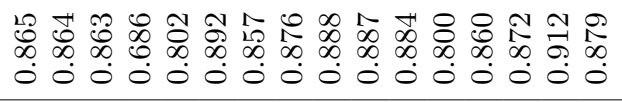 & \\
\hline & & & ָั & 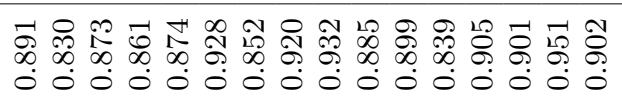 & \\
\hline & & & $\overrightarrow{\mathbb{N}^{2}}$ & 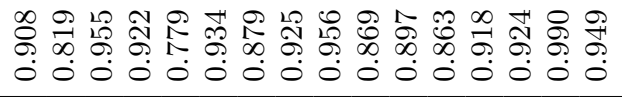 & \\
\hline & & & 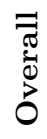 & 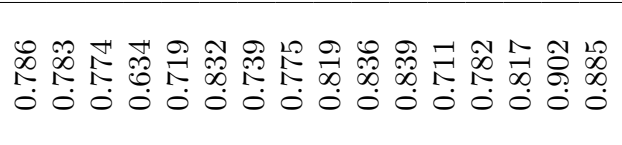 & \\
\hline 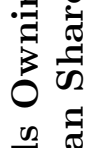 & $\frac{1}{ \pm}$ & & $\begin{array}{l}00 \\
10 \\
2 \\
0 \\
0\end{array}$ & 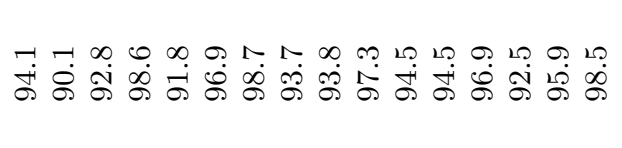 & \\
\hline 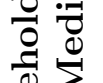 & 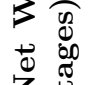 & & $\frac{9}{10}$ & 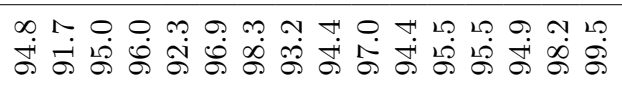 & \\
\hline อี & ¿ี & $\theta$ & 吾 & 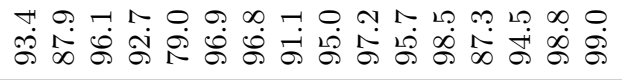 & \\
\hline 象 & 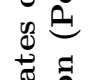 & : & Did & 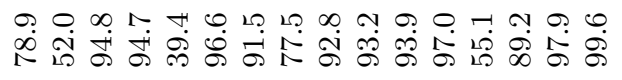 & \\
\hline రై & 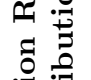 & 8 & ลี & 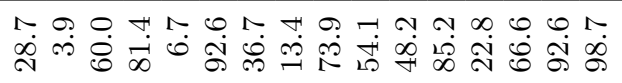 & \\
\hline N & .0 & & $\overrightarrow{\mathbb{N}_{1}}$ & 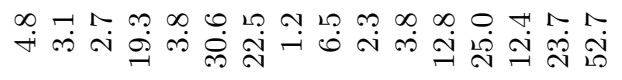 & \\
\hline$\frac{0}{\frac{0}{6}}$ & مَّ & & 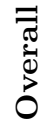 & 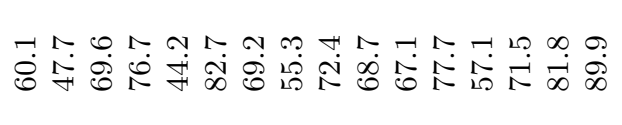 & \\
\hline & & & & 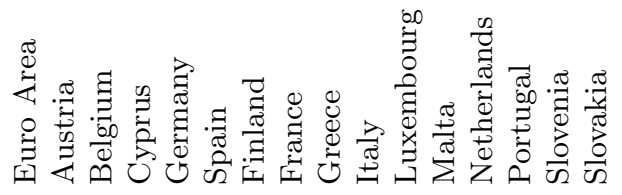 & בֶ. \\
\hline
\end{tabular}




\begin{tabular}{|c|c|c|c|c|}
\hline \multirow{7}{*}{ 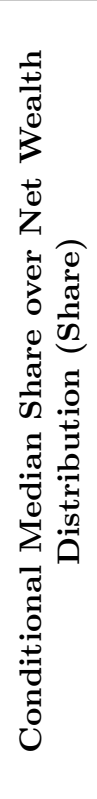 } & \multirow{7}{*}{ 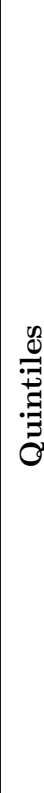 } & 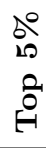 & 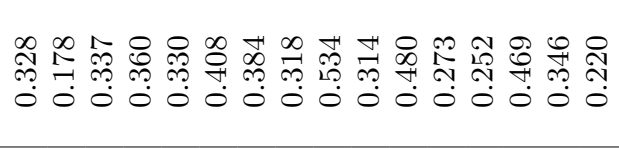 & \multirow[b]{15}{*}{ 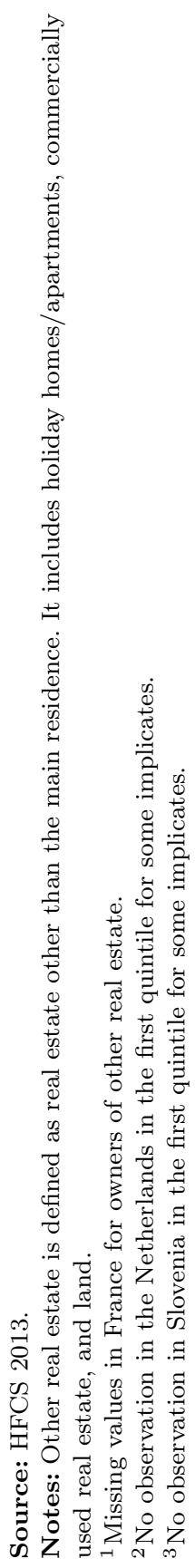 } \\
\hline & & $\frac{1}{10}$ & 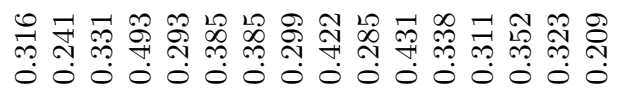 & \\
\hline & & $\underset{f}{\stackrel{q}{7}}$ & 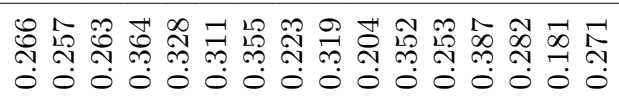 & \\
\hline & & in & 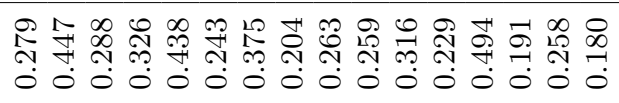 & \\
\hline & & $\stackrel{\text { N }}{\tilde{N}}$ & 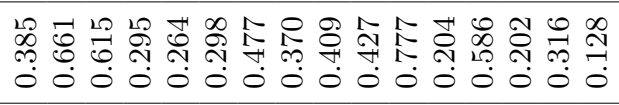 & \\
\hline & & $\overrightarrow{\omega_{n}}$ & 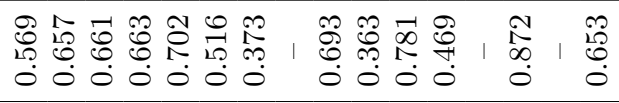 & \\
\hline & & ס & 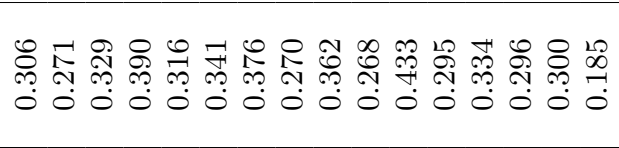 & \\
\hline 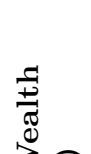 & & 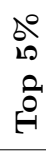 & 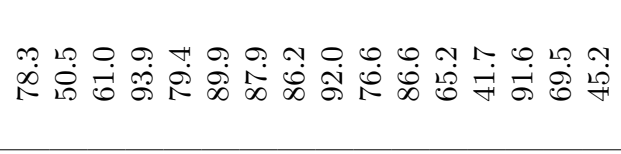 & \\
\hline $\begin{array}{l}3 \\
+\infty \\
0 \\
0\end{array}$ & & $\frac{7}{10}$ & 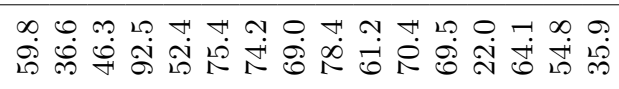 & \\
\hline 乙. & q & $\stackrel{g}{\rightleftarrows}$ & 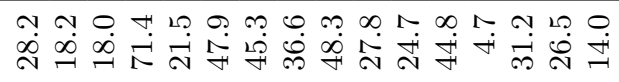 & \\
\hline 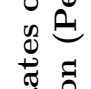 & :ב & రై & 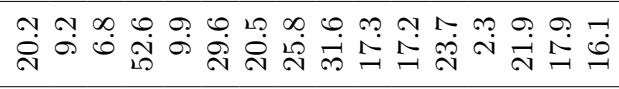 & \\
\hline 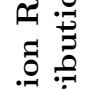 & $\theta$ & $\overrightarrow{\mathrm{N}}$ & 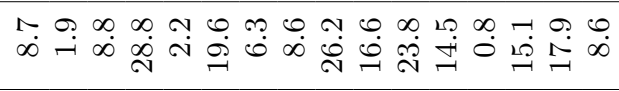 & \\
\hline مُ & & $\vec{n}$ & 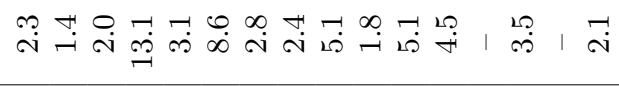 & \\
\hline & & 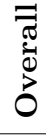 & 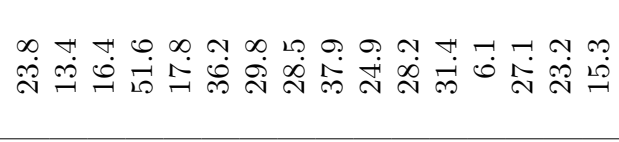 & \\
\hline & & & 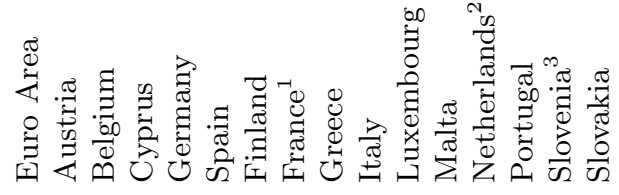 & \\
\hline
\end{tabular}


Vol. 12 No. 2 How Do Households Allocate Their Assets?

\begin{tabular}{|c|c|c|c|c|}
\hline 壱 & \multirow{7}{*}{ 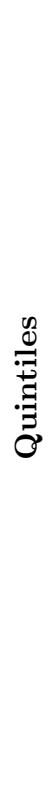 } & 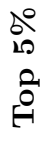 & 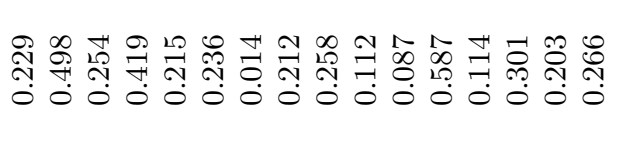 & \multirow{15}{*}{ 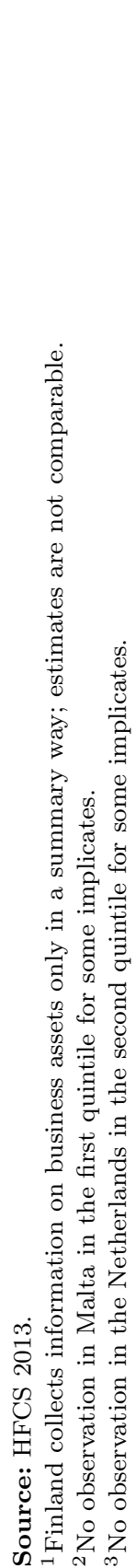 } \\
\hline \multirow{6}{*}{ 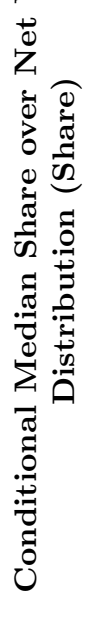 } & & $\frac{5}{\sqrt{10}}$ & 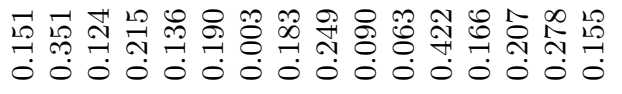 & \\
\hline & & $\stackrel{9}{\ddagger}$ & 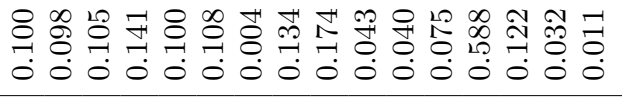 & \\
\hline & & के & 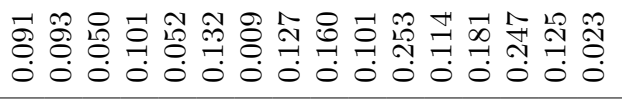 & \\
\hline & & ลี & 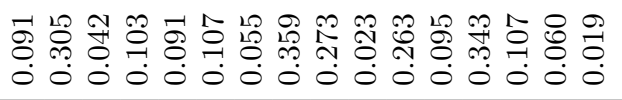 & \\
\hline & & $\overrightarrow{\omega_{0}}$ & 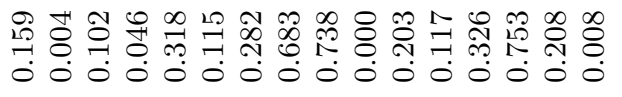 & \\
\hline & & 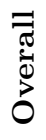 & 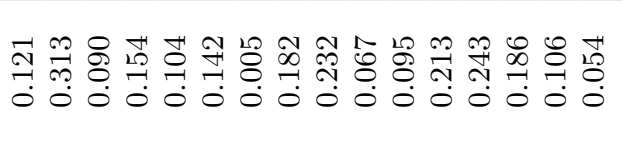 & \\
\hline \multirow{7}{*}{ 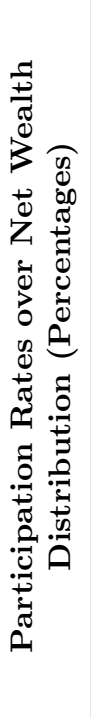 } & \multirow{7}{*}{ 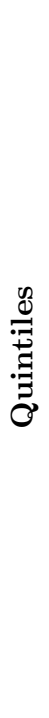 } & 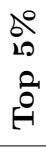 & 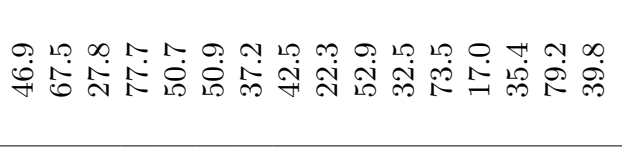 & \\
\hline & & $\frac{1}{10}$ & 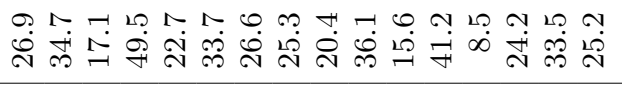 & \\
\hline & & $\stackrel{9}{\$}$ & 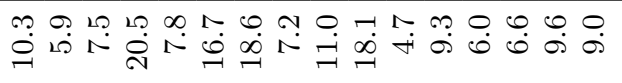 & \\
\hline & & कृ & 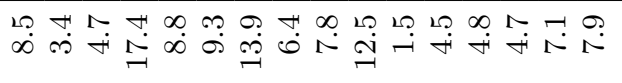 & \\
\hline & & 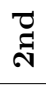 & 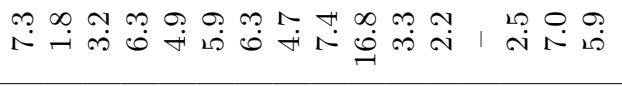 & \\
\hline & & $\vec{n}$ & 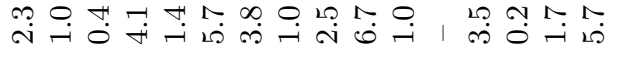 & \\
\hline & & 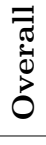 & 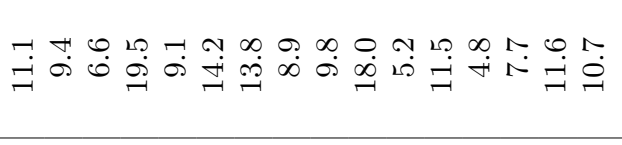 & \\
\hline & & & 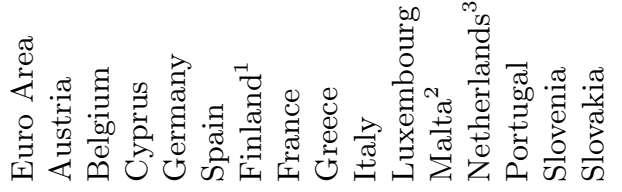 & \\
\hline
\end{tabular}


exception of Cyprus, Finland 10 Italy, and, to some degree, Spain, where ownership rates start to increase at a lower net wealth quintile than in other countries. The conditional portfolio shares along the net wealth distribution (see table 4) display a very high degree of cross-country heterogeneity.

\subsubsection{Financial Assets over the Wealth Distribution}

By far the most commonly held assets are safe financial assets. These are held by almost every household, whether rich or poor (see table 5): 93 percent of the households in the euro area in the lowest wealth quintile hold safe financial assets, and this share increases to 99 percent for the highest wealth quintile. The conditional median portfolio share in the euro area is 12 percent. For the poorest 20 percent in the euro area, the portfolio share is, however, much higher at 60 percent. As expected, the picture for risky financial assets is very different (table 6). Overall, only 20 percent of the euro-area households hold such assets, which is an illustration of the "stock market participation puzzle" commonly mentioned in the literature. For each country, this percentage increases with wealth. In the fifth net wealth quintile, it ranges between 8 percent (Slovakia) and 67 percent (Finland). The conditional median portfolio share is low at 5 percent for the euro area.

\section{Determinants of Asset Ownership Rates}

\subsection{Model Specification}

We focus on the household main residence, other real assets, and risky financial assets and estimate the ownership and conditional portfolio shares of these assets with a multivariate model. For each of these assets categories, the asset ownership (dummy that equals 1 if the household holds a certain asset category) and the portfolio share is analyzed for the euro area as a whole and each country separately by applying a probit and tobit model, respectively 11 All estimations

\footnotetext{
${ }^{10}$ In Finland, information on business wealth is only collected in a summary way and hence the estimates are not comparable.

${ }^{11}$ While the former estimator is standard in the participation literature, the latter is used when the data do not include variables that could plausibly influence the participation decision but not the share conditional on participation.
} 
Vol. 12 No. 2 How Do Households Allocate Their Assets?

\begin{tabular}{|c|c|c|c|c|c|}
\hline \multirow{7}{*}{ 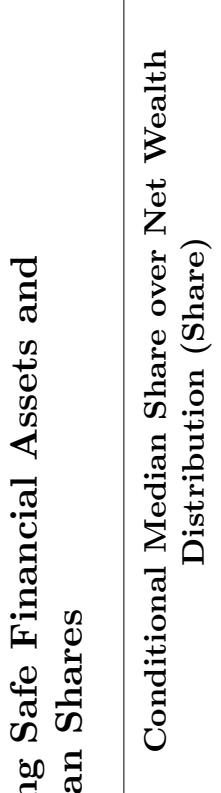 } & \multirow{7}{*}{ 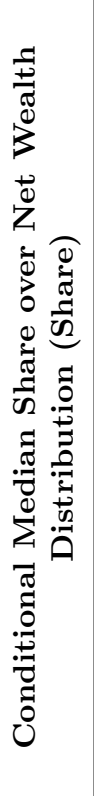 } & \multirow{7}{*}{ 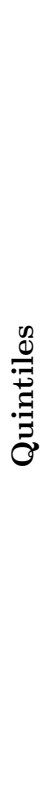 } & مी & 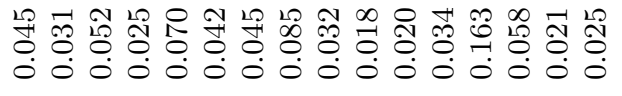 & \\
\hline & & & $\frac{1}{10}$ & 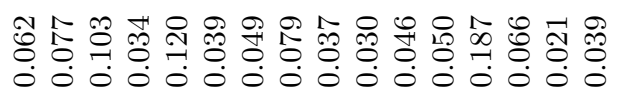 & \\
\hline & & & $\frac{5}{\#}$ & 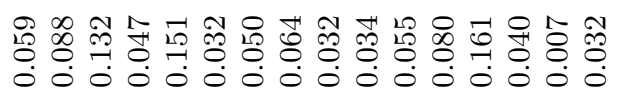 & \\
\hline & & & అึ. & 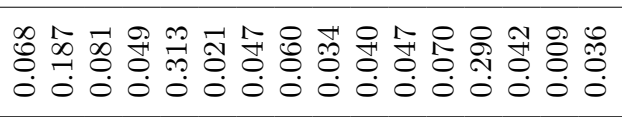 & \\
\hline & & & సี & 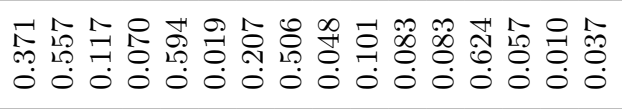 & \\
\hline & & & $\vec{\omega}$ & 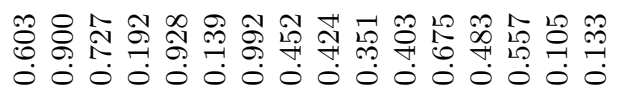 & \\
\hline & & & 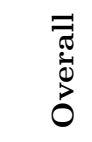 & 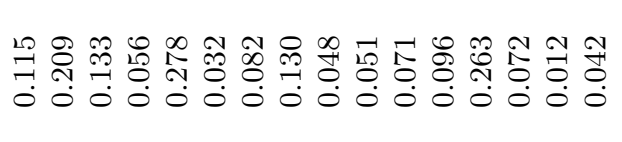 & \\
\hline$\sum^{1} \sum_{1}^{0}$ & & & 告 & 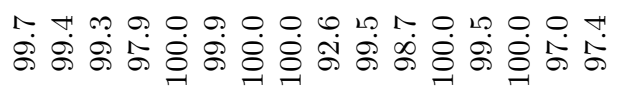 & \\
\hline 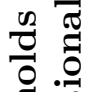 & $\sum^{\pi}$ & & $\frac{7}{10}$ & 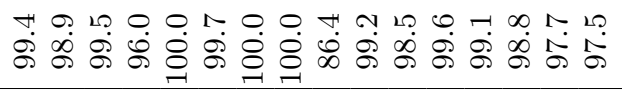 & \\
\hline 密 & 乙 & & $\stackrel{9}{ \pm}$ & 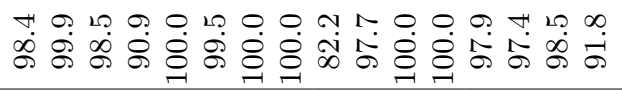 & \\
\hline$\underset{1}{0}$ & $\begin{array}{ll}0 \\
0 \\
0 & 0 \\
0 & 0\end{array}$ & 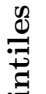 & Dึ & 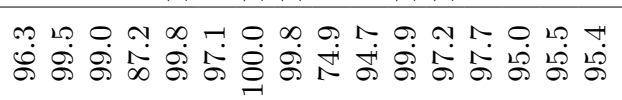 & \\
\hline 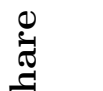 & 苟 & $\tilde{\sigma}$ & ลี & 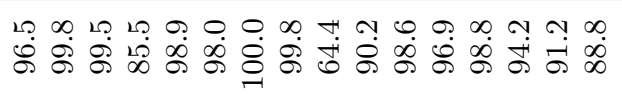 & \\
\hline فما & 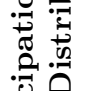 & & $\overrightarrow{w_{0}}$ & 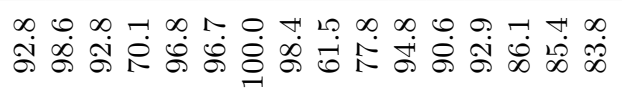 & \\
\hline$\frac{0}{\frac{0}{6}}$ & مَ" & & 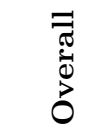 & 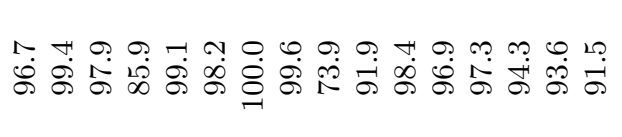 & 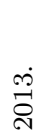 \\
\hline & & & & 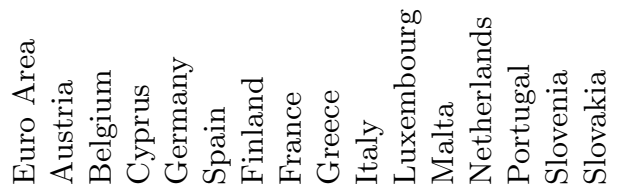 & 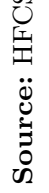 \\
\hline
\end{tabular}




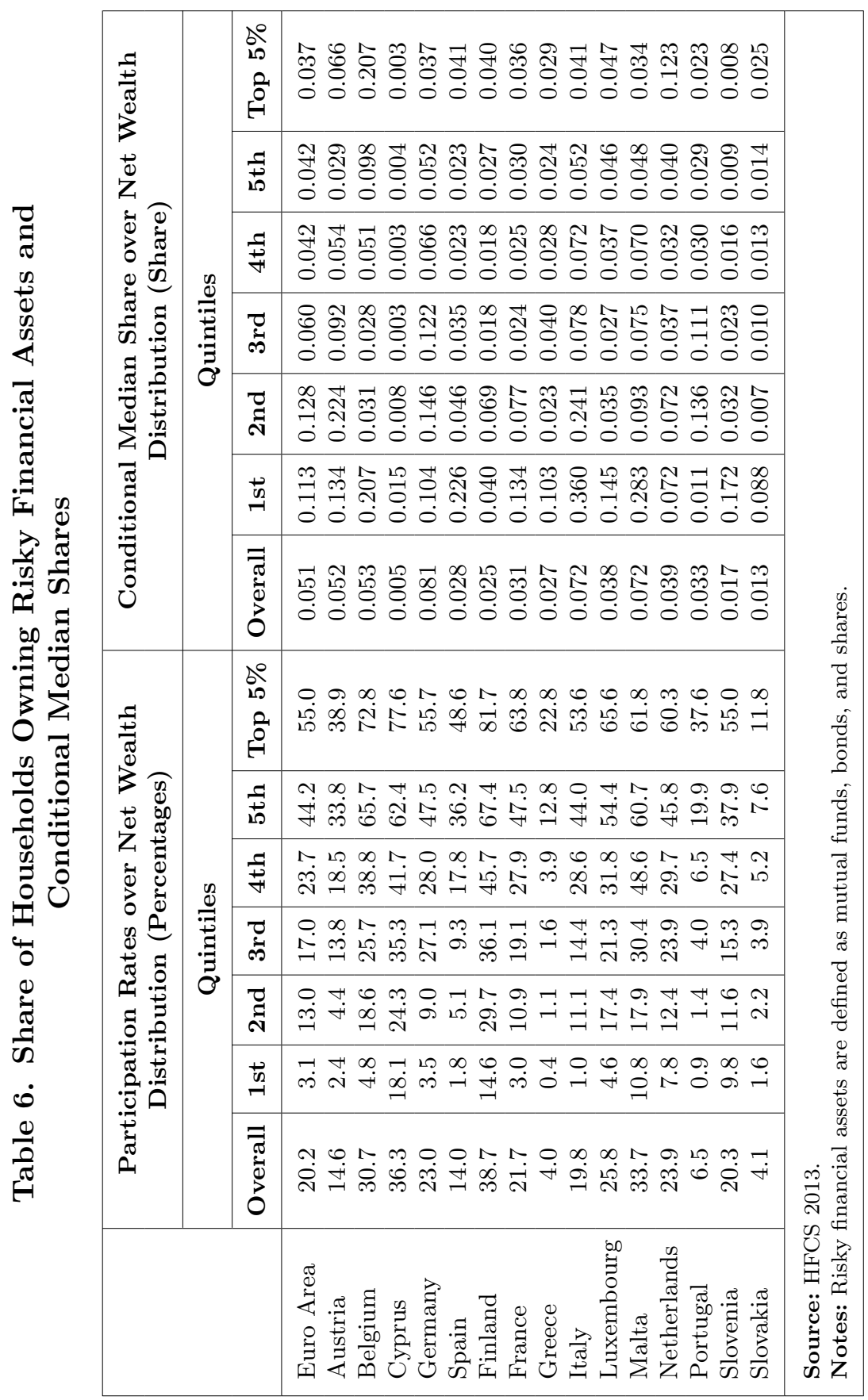


take appropriate household weights as well as the imputation structure into account. In particular, both the probit and the tobit models make use of the final household weights, and the resulting average marginal effects are population estimates. The standard errors are based on 100 replicate weights. Trying to find systematic relationships between socioeconomic characteristics and households' asset composition or investment behavior, there are plenty of traits that could be potentially relevant. In line with the household finance literature, the following determinants commonly used are considered 12 : household composition (household type, gender and marital status of the reference person), age, education, inheritance received, labor market situation (employment status), and resources (net wealth and income distribution quintiles).

Net wealth is an endogenous explanatory variable by construction since each asset component is part of the net wealth definition. However, as demonstrated in the descriptive analysis above, the position in the net wealth distribution is a (very) important factor for the explanation of the portfolio composition, and hence we need to control for the household's position in the distribution of net wealth when investigating the conditional correlations. Addressing this endogeneity, either the indicator for the position of a household in the net wealth distribution can be dropped or, as is sometimes done in the literature, the specific type of asset that is modeled can be excluded and the remaining "aggregate wealth" distribution can be used. The latter approach has the weakness that the household's position in the distribution of the remaining wealth ceases to be a good indicator for its position in the overall net wealth distribution. This problem is particularly pronounced if major wealth components are excluded. Furthermore, one does not condition on the same indicator of the wealth distribution in the different models (i.e., each model for the separated asset types) that are estimated below. Thus, we take the model including the net wealth quintiles and examine systematic correlations between wealth and asset behavior of households, without attributing a causal role to wealth. In appendices 3 and 5 , we additionally provide results of the model where the indicator for the household position in the net wealth distribution (and the

\footnotetext{
${ }^{12}$ See detailed definitions in appendix 6 .
} 
indicator for the marital status of the household reference person) is excluded from the explanatory variables. The fundamental results remain unchanged, but this exclusion has an impact on some variables. In particular, variables other than the wealth quintiles gain significance, typically because they act as proxies for the excluded wealth component.

The results presented in the tables refer to average marginal effects derived from the probit models introduced above. Thus, the estimates can be interpreted in terms of a conditional increase in the likelihood of holding a certain asset type in a given country relative to the baseline. For example, we investigate whether conditional on all other factors there are relatively more single parents that own the household main residence compared with the baseline, which in this case is a household with a single occupant. Due to space constraints, we discuss only the results of the specification 13 concerning the extensive margin for the household main residence and risky financial assets. Results for other specifications are provided in the tables in appendices 2 and 4 and are discussed only very briefly in the text. All tables contain the estimation results for each individual country as well as the euro area as a whole. The euro-area results are provided as a point of reference.

In what follows, we report stylized facts, i.e., results for variables that exhibit both a fairly systematic cross-country relationship and a significant relationship with respect to the particular asset analyzed. Our informal rule for classifying an observed relationship as a stylized fact is that the empirical result should be statistically significant in the estimation for the euro area as a whole. To make sure that the "stylized fact" is not driven by only a few (large) countries, we require additionally that (i) an analogous (and statistically significant) coefficient estimate is observed in at least eight euro-area countries under consideration (the so-called 50 percent rule), and (ii) there is maximal one country with an opposite significant coefficient estimate (the so-called exception to the rule).

\footnotetext{
${ }^{13}$ The specification referred to in the main text includes an indicator for the position of the household in the net wealth distribution. Results for an alternative specification of the model excluding net wealth and marital status are provided in appendices 3 and 5 .
} 


\subsection{Stylized Facts}

Fact 1: The probability of ownership of the household main residence, other real estate, risky asset assets, and business ownership is positively related to net wealth and for risky assets that probability is positively related to income as well. The portfolio shares of other real estate, risky assets, and business ownership are increasing in net wealth, whereas that of the household main residence is hump shaped, first increasing in wealth and thereafter decreasing.

The difference in the probability of owning an asset between the first and the fifth quintile of the net wealth distribution (the wealthiest versus the poorest) is substantial in each country and in every type of asset considered (see tables 7 and 8; also see tables 16 and 17 in appendix 2). This implies that wealthier households have more portfolio breadth in all euro-area countries, consistent with Carroll's (2002) report for the United States. Even after controlling for the position in the net wealth distribution, households with higher incomes are more likely to hold risky financial assets. Especially for the highest income quintile, the estimated average marginal effects are positive and statistically significant (exceptions are Greece, Malta, Slovenia, and Slovakia) (table 8). This is consistent with intertemporal portfolio models with fixed costs; higher income and higher wealth are associated with more demand for risky assets and, for given entry or participation costs, a higher probability to overcome the threshold and decide that it is worthwhile to enter the asset market or remain in it.

One observes some differences in the magnitude of the marginal effects of the net wealth and income variables across countries. Such heterogeneities are likely to be due to differences in transaction and information costs and may be driven by institutional specificities (such as the functioning of mortgage markets, housing market conditions, or social security systems). This issue is investigated in section 5. Whereas households higher up the net wealth distribution tend to have a larger portfolio share of other real estate, risky assets, and business ownership, the portfolio share of the household main residence is a striking exception to this rule. Initially increasing with wealth, it ultimately decreases (table 9). The particular 


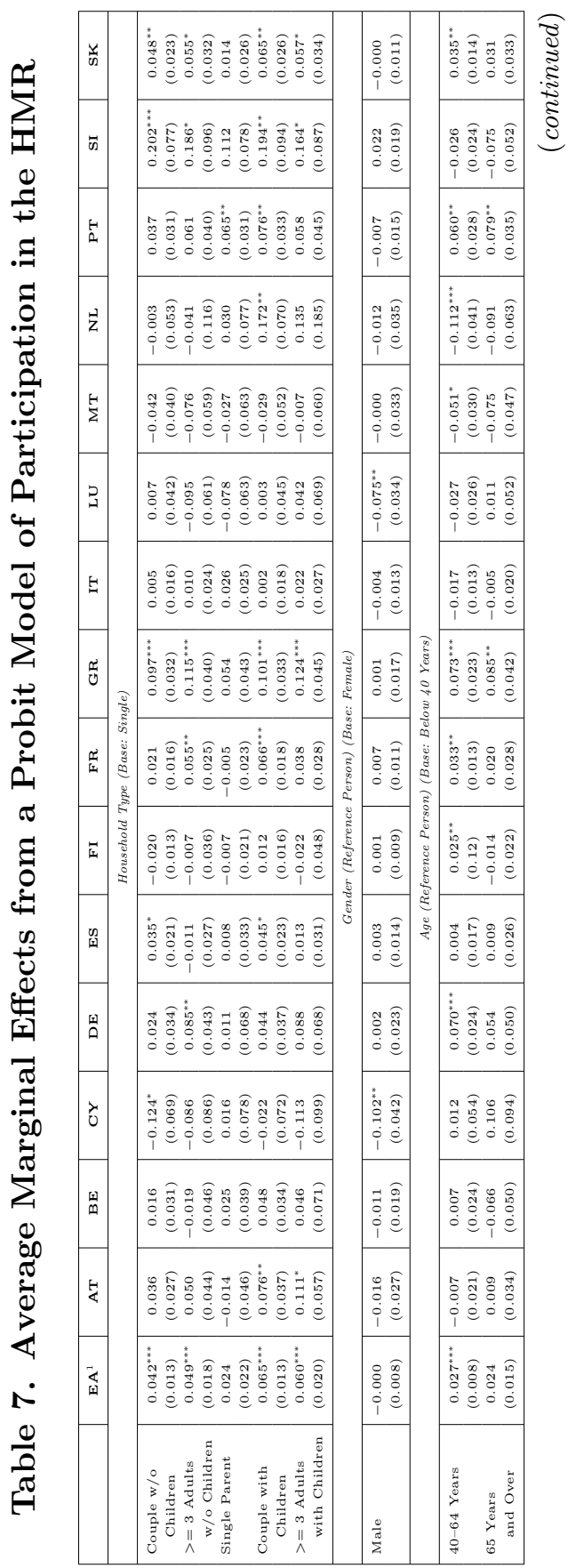


Vol. 12 No. 2

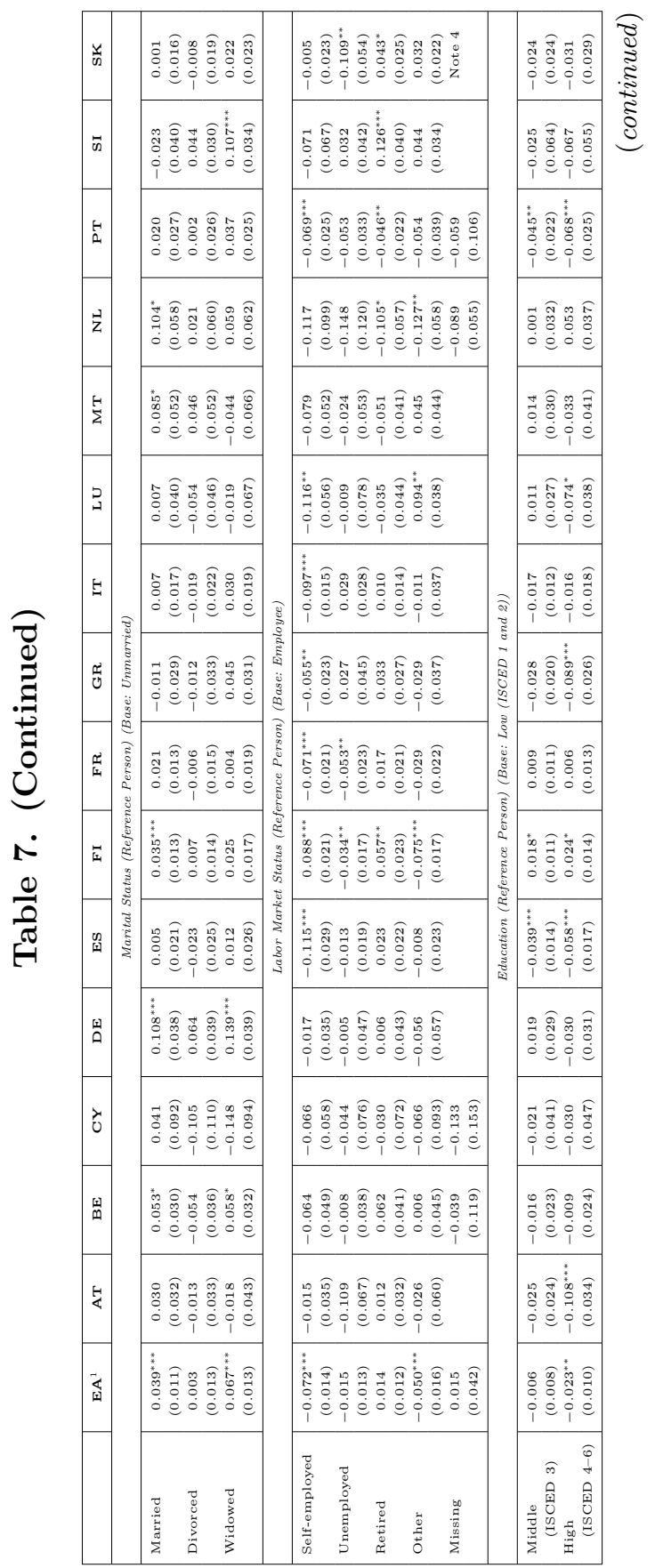




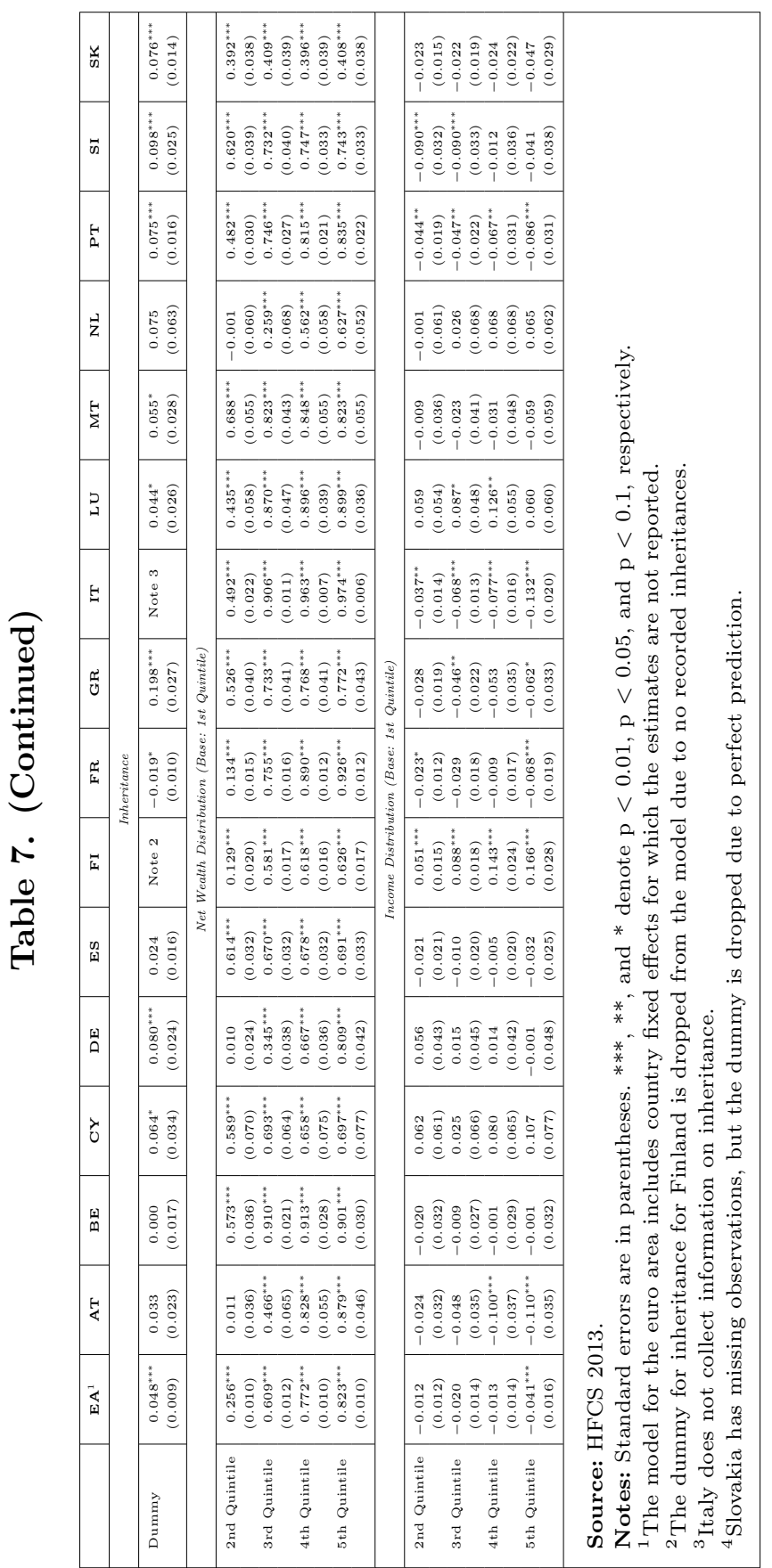


Vol. 12 No. 2 How Do Households Allocate Their Assets?

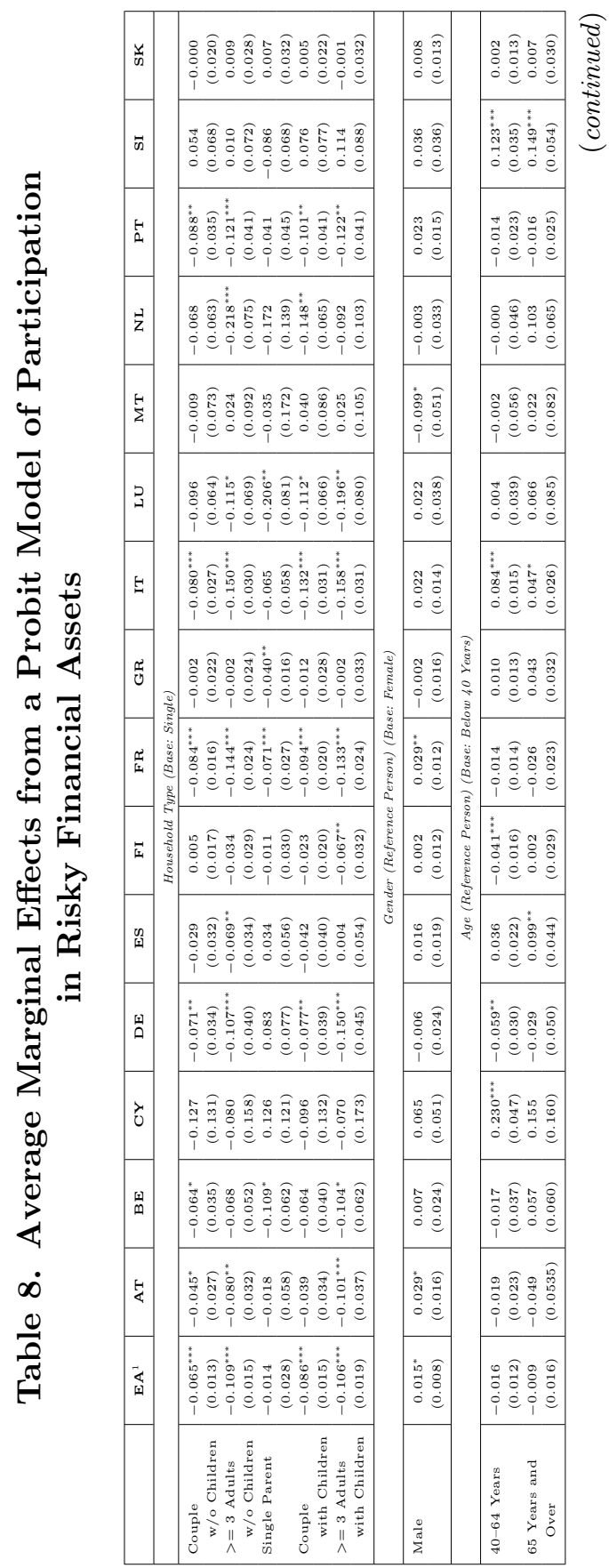




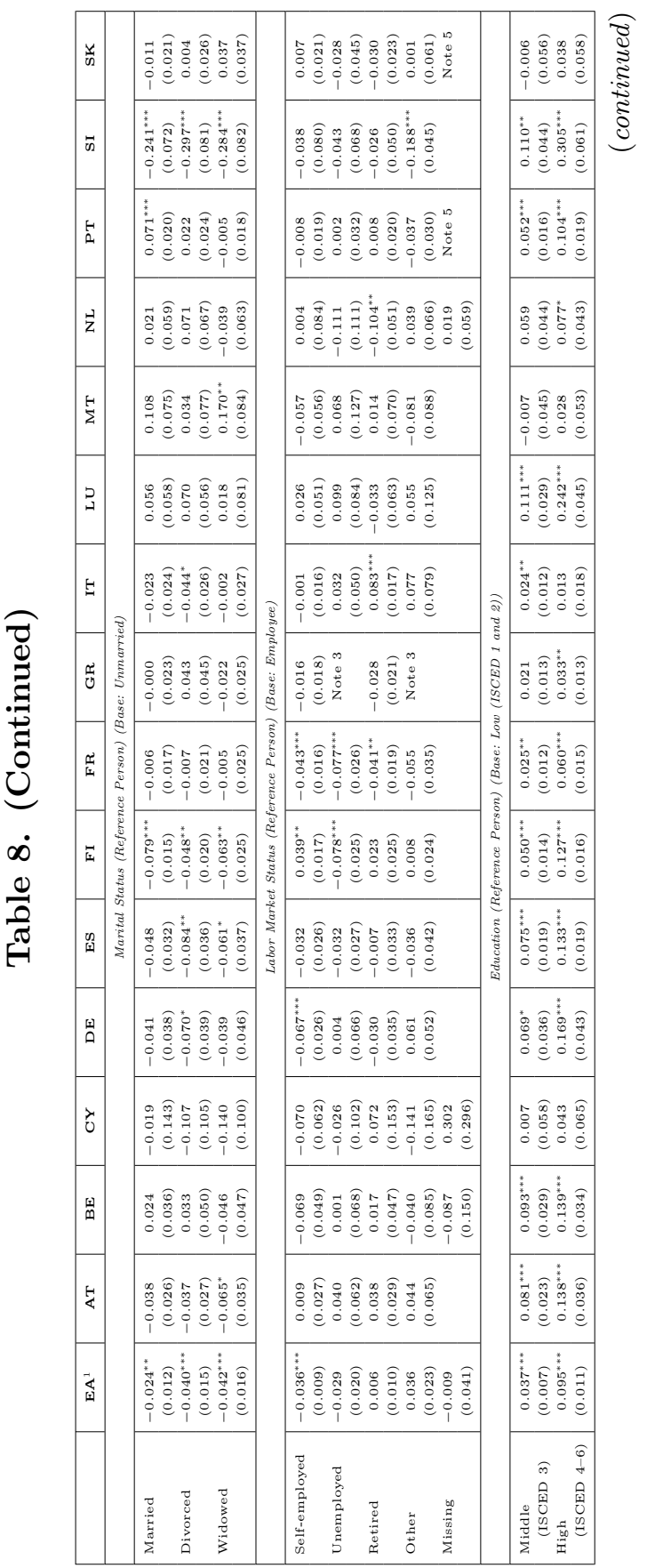


Vol. 12 No. 2 How Do Households Allocate Their Assets?

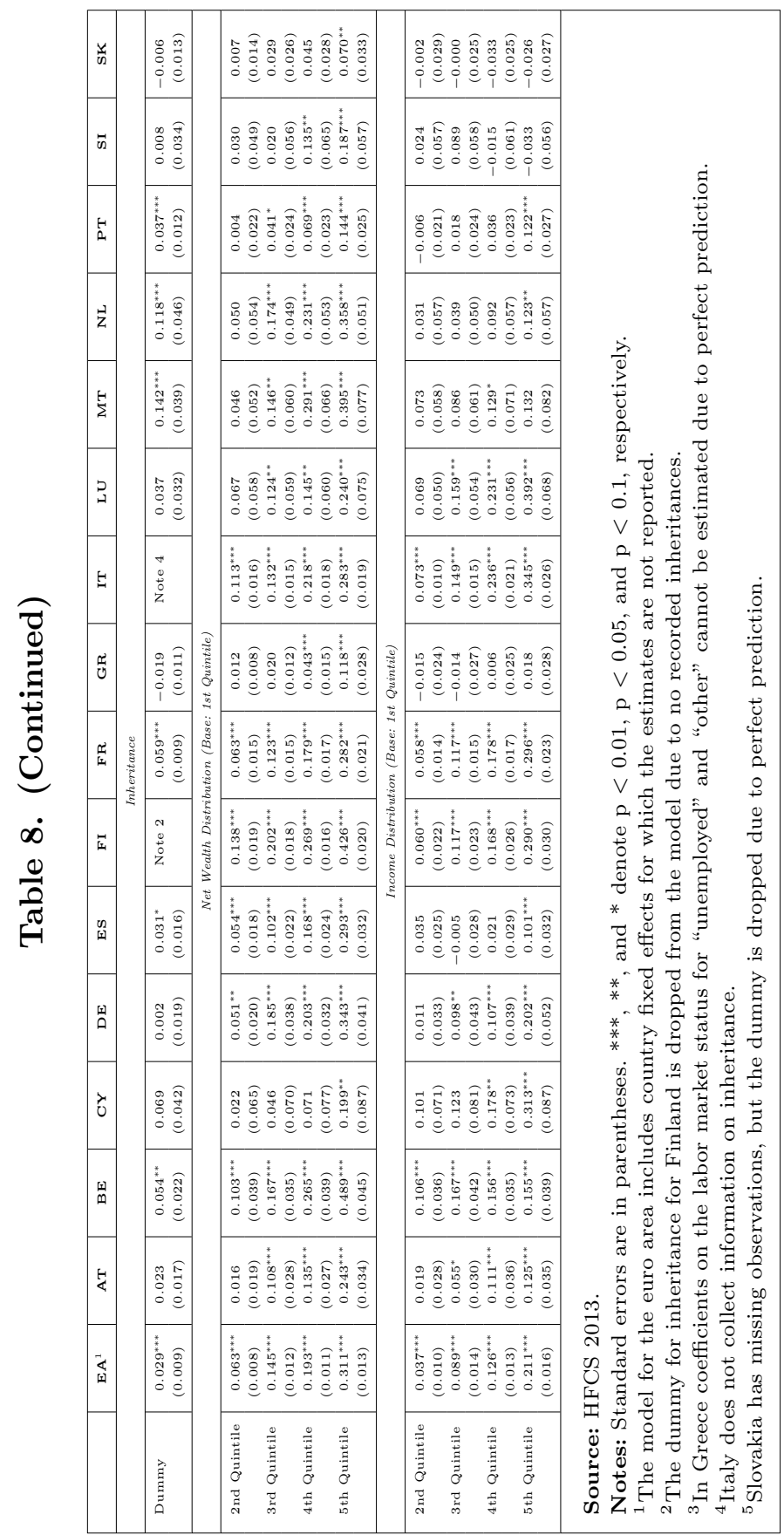




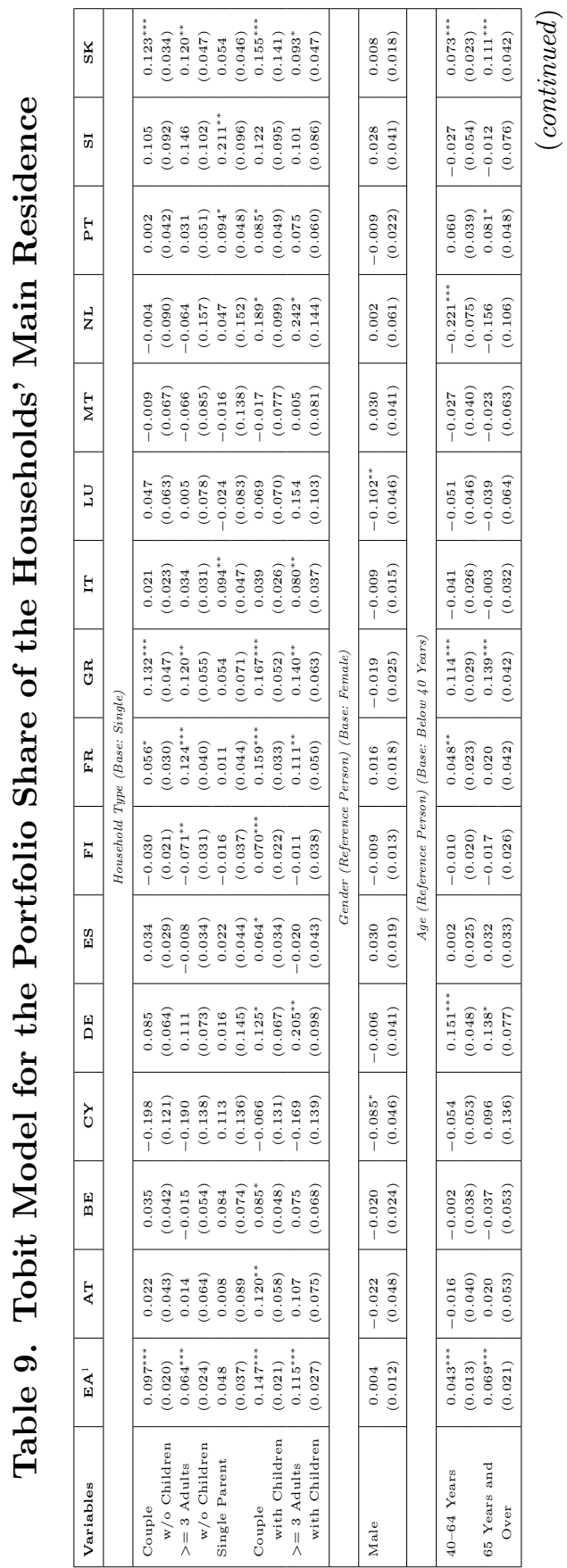




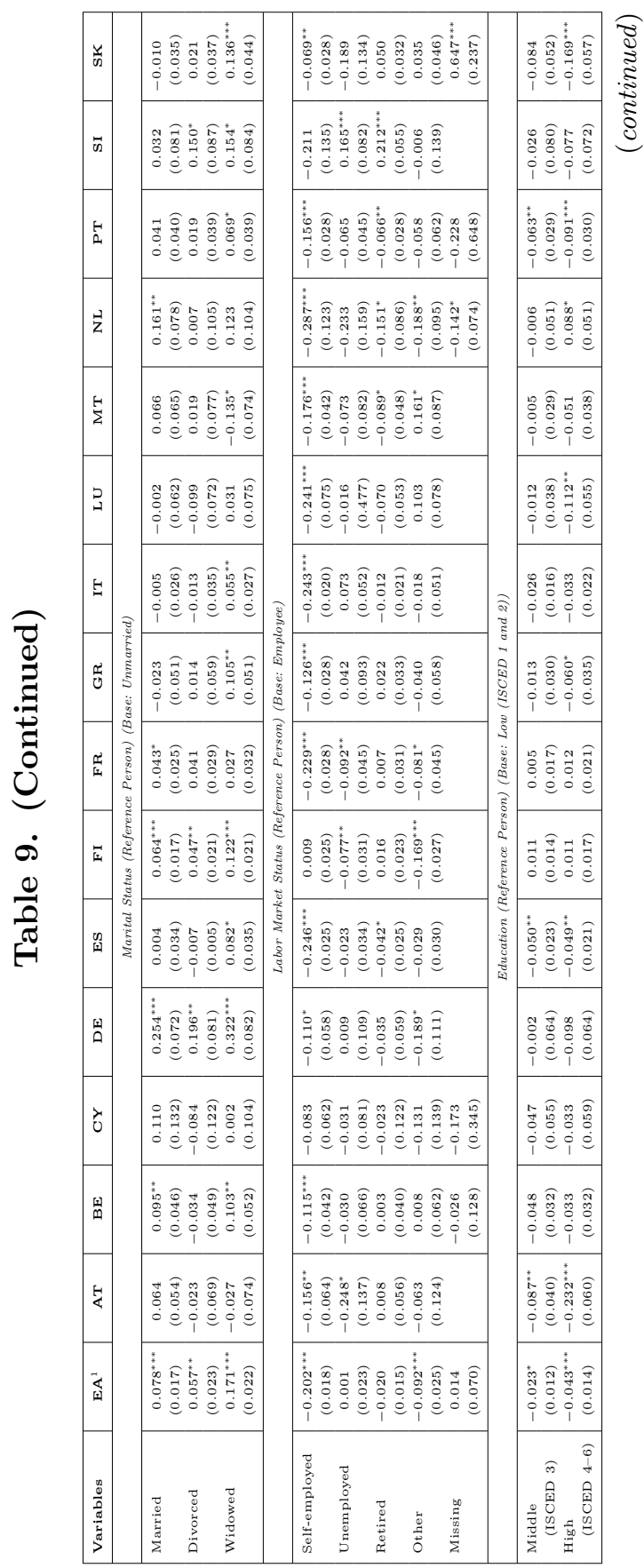




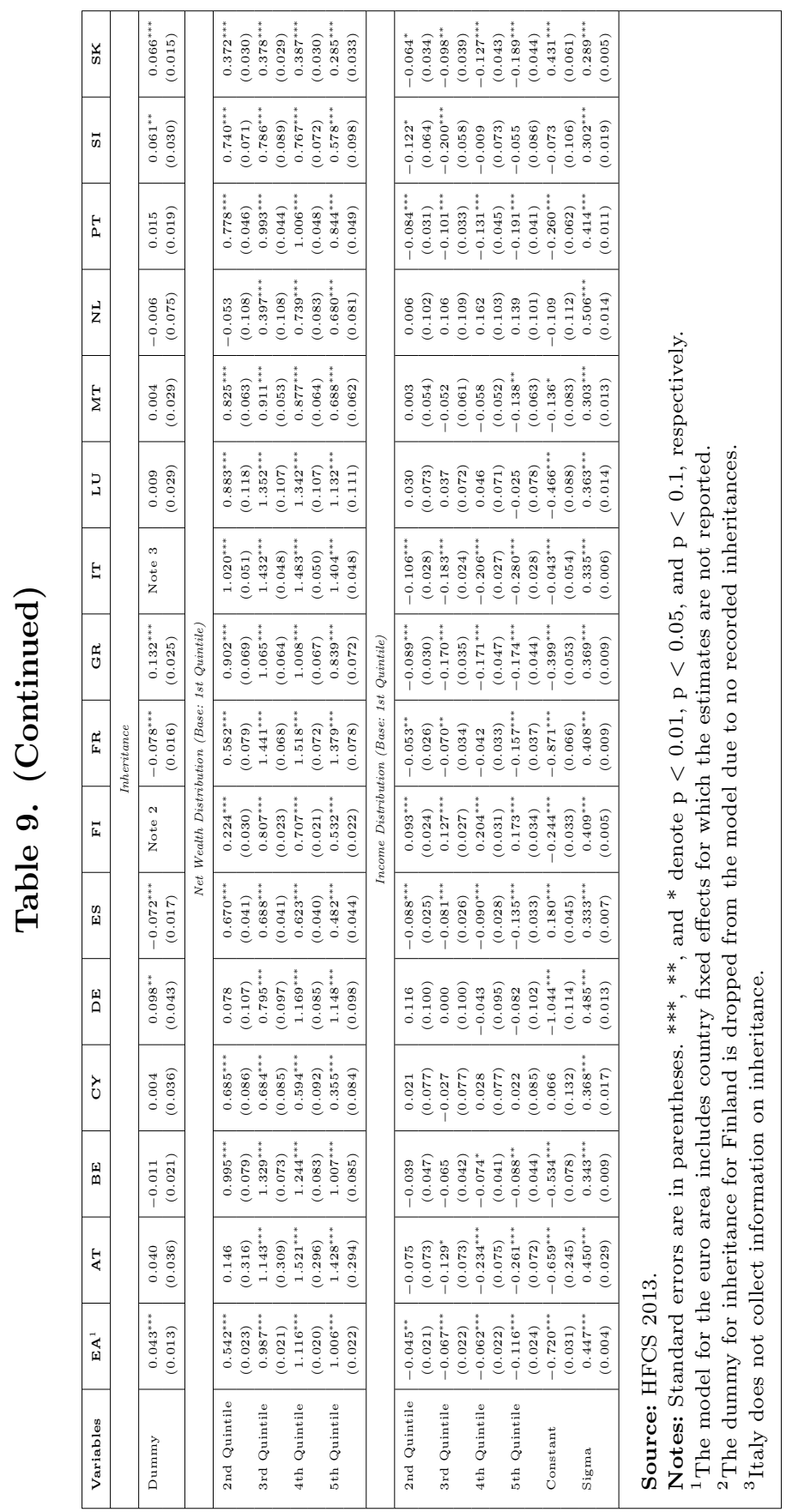


nature of the household main residence as both an asset and consumption good provides a natural explanation. Whereas there is no natural limit in the value of ownership assets bought for investment or business purposes, the main residence serves a consumption purpose where the law of diminishing marginal utility of the housing services provides a natural limit to the value (and related size) of the main residence. For all countries, we find that households in the fifth quintile of the net wealth distribution do not have a higher portfolio share of the main residence compared with the fourth quintile.

Fact 2: The probability of owning the main residence and other real estate is positively linked to previously having received inheritances. The portfolio share of other real estate is higher for households having received an inheritance in the past.

In the euro area as a whole and in eight countries individually, the inheritance dummy is a positively significant factor in explaining ownership of the household main residence (table 7) 14 This effect is much expected, as clearly some households have inherited their household main residence or have used the proceeds of any bequests and gifts to acquire a dwelling for use as their household main residence. In some countries, the effect can be quite sizable. In Germany, for instance, a country with a low HMR ownership rate (44 percent) overall, having received an inheritance increases households' likelihood to own their main residence by 8 percentage points. In Greece, the average marginal effect is a very large 20 percentage points. Also in nine countries and the euro area as a whole, the inheritance dummy is significant and positively related to other real estate ownership (which includes holiday homes) (table 16). In Spain, a country with a high rate of other real estate ownership (36 percent), probably related to holiday homes, the average marginal effect is largest with 22 percentage points. As family tradition is known to influence bequest behavior (Cox and Stark 2005), these cross-country differences are likely to reflect varying cultural traditions of passing houses down through generations. However, only in four countries

\footnotetext{
${ }^{14}$ France has a small negative coefficient, which is puzzling, as it is the only country with such a negative sign.
} 
does having received an inheritance imply that the portfolio share of the main residence for such a household is higher (table 9). This can be contrasted with the portfolio share in other real estate, which for ten countries is higher for households that received an inheritance (table 22 in appendix 4).

Fact 3: Couples with dependent children both are more likely to own and are more likely to have a higher portfolio share of the household main residence (relative to singles). This coincides with a significantly lower portfolio share of risky assets.

In eight countries and the euro area as a whole, we find that couples with children are significantly more likely to own their household main residence relative to singles (table 7). Similarly, in eight countries and the euro area as a whole, these households hold significantly lower portfolio shares of risky assets (table 10). One possible rationale is that house ownership has large reversibility costs, so it is economically meaningful to wait until family structure is more certain before deciding on homeownership. Singles, especially young ones, are likely to be more uncertain about future family structure. As houses are a major and lumpy investment for households, it is natural that portfolio shares of other assets are necessarily reduced.

Fact 4: The probability of owning and the portfolio share of risky assets is positively related to the educational attainment of the household (head).

Having a higher education increases the likelihood of owning and the portfolio share of risky assets (table 8, table 10). This effect could reflect various underlying factors. It could be linked to a permanentincome effect, if education is positively associated with future income profiles and higher expected wage earnings. It could also be linked to a background risk effect (especially unemployment risk); educated people may face lower unemployment risk, and thus they could be incited to invest in risky financial assets (Guiso, Jappelli, and Terlizzese 1996, Heaton and Lucas 2000). Finally, there is a wide literature on financial literacy which shows that less educated people are less likely to hold stocks (see, for instance, van Rooij, Lusardi, and Alessie 2011). 
Vol. 12 No. 2

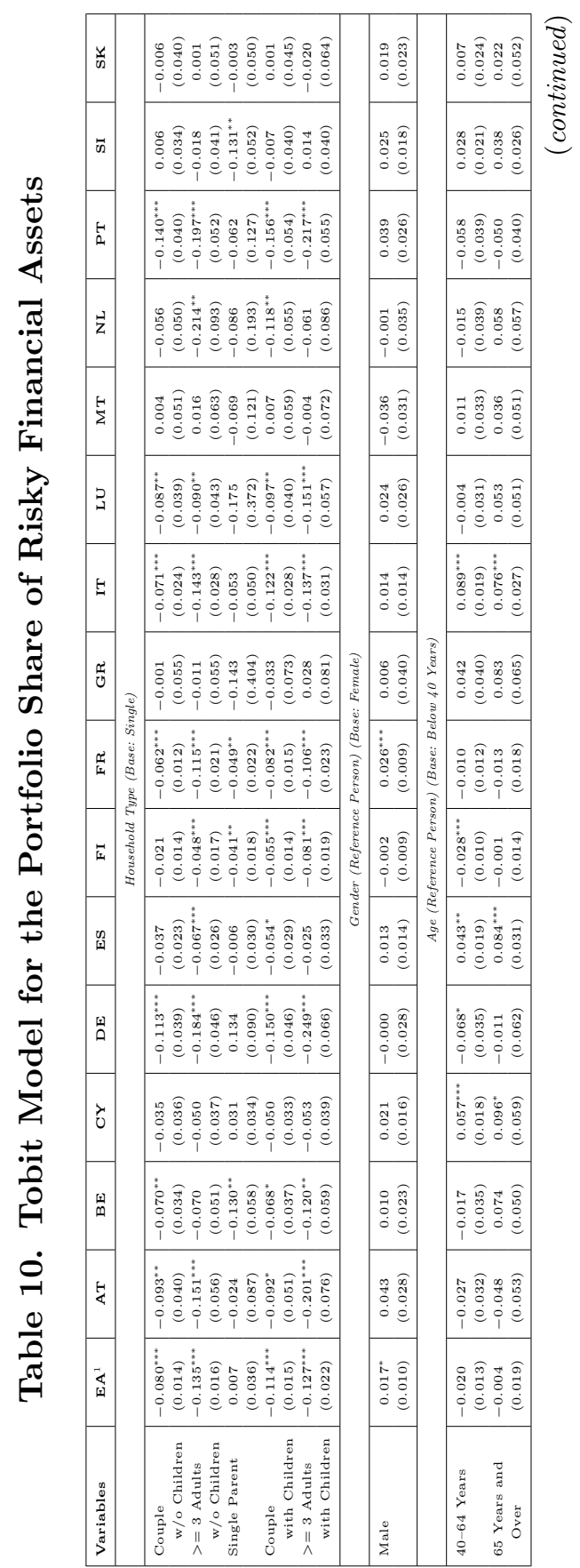




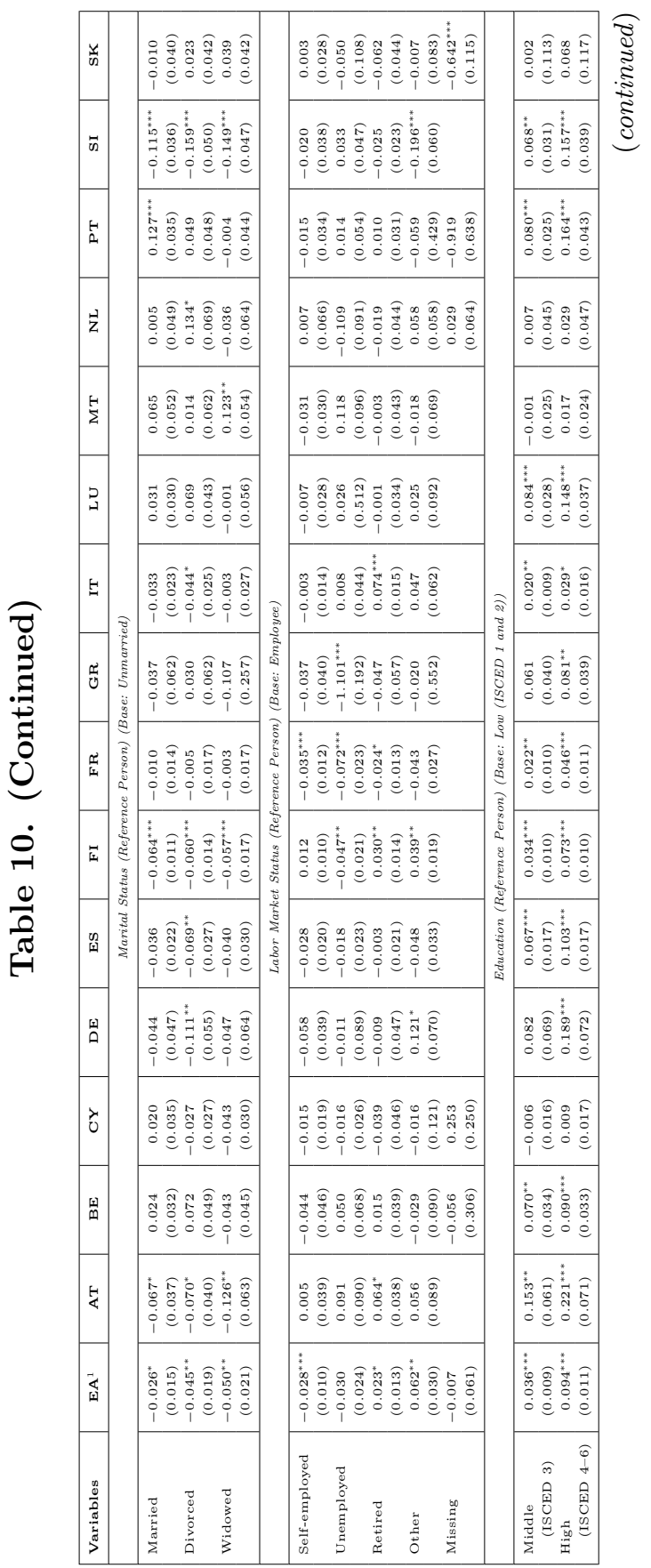


Vol. 12 No. 2 How Do Households Allocate Their Assets?

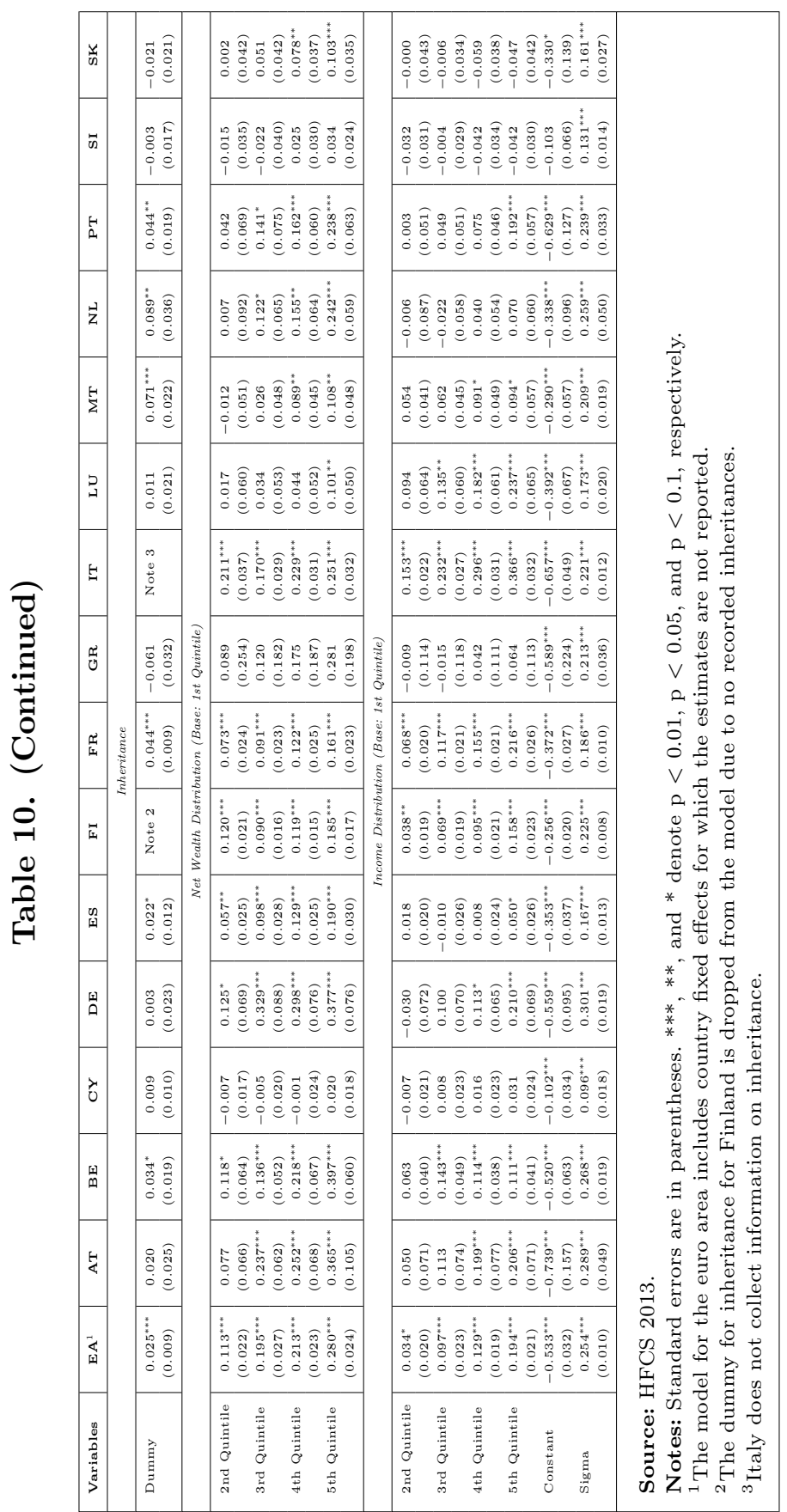


Fact 5: The probability of owning and the portfolio share of risky assets are higher for single households.

In eight countries, and the euro area as a whole, relative to households with at least three adults (with or without children), single households are much more likely to own risky assets. Also, relative to such households and to couples with children, the portfolio share of risky assets is higher for single households. One likely factor is that having responsibilities for children and/or a partner increases the risk aversion. It could also simply reflect that having children implies certain committed expenditures that households may have to meet, so that they are less prone to take additional financial risks when they have children.

Fact 6: Varying labor market statuses have remarkably little effect on ownership and portfolio shares of assets, with the obvious exception of the self-employed being much more likely to own businesses (and to some extent other real estate).

There is little systematic difference between being employed or unemployed and being employed or retired in the ownership of assets (tables 7, 8, 16, and 17). This implies that unemployment (after controlling for income, education, and relative wealth position) has little explanatory power for the asset participation decision. A possible explanation may be that unemployment is considered a transitory and unexpected event in life. Given quasi-universal unemployment insurance in the European Union, the lack of any significant link may indicate the ability of the unemployed to survive the unemployment spell without having to liquidate (at least partially) the assets in question.

\subsection{Other Findings}

In any cross-country regression analysis that contains a large set of countries, one is prone to identify coefficients that are statistically significant and of the same sign in a subset of countries; however, there are fewer countries than needed to speak of a stylized fact. Such findings may be due to institutional cultural or economic phenomena that are shared by certain groups of countries but not by 
others. Alternatively, the absence of statistical significance for some countries might just be due to sampling (i.e., some facts pertain to subgroups of the population which might not be numerous enough to reach statistical significance). And anomalies are present when individual countries have significant opposite coefficients that deviate from the general pattern. Country differences in terms of sign and magnitude of the coefficients (and level of significance) also occur frequently. Besides natural sampling variation, institutional or economic differences play a role. Such country differences will have to be explained in further research projects

An interesting fact in the HFCS data set is that higher education, controlling for income and wealth, seems to indicate a reduction in the likelihood of owning the main residence (statistically significant in only some countries - e.g., Austria, Spain, Greece, and Portugalbut also in the euro area as a whole). This is probably linked to a need for more mobility of more educated people and a delayed decision to settle down and to become a homeowner.

The likelihood of owning the HMR for households with a selfemployed reference person is significantly lower than for an employee in the euro area as a whole and in several Southern European countries (e.g., in Spain, Portugal, Greece, and Italy). A possible explanation may be that the "living area" of the self-employed is part of the business assets (think, e.g., a small restaurant or shop owner whose living space is under the same roof as the restaurant or shop).

An interesting result is that households with three or more adults with dependent children tend to have a higher portfolio share for the household main residence compared with single households. The coefficient is statistically significant for Germany, France, the Netherlands, Italy, Greece, and Slovakia. This reflects the obvious need for more space of households with more household members.

\section{Cross-Country Differences in Coefficient Estimates and Institutional Factors}

Identifying the sources of the differences in the estimated effects of the demographic variables on the conditional mean for certain assets categories across countries is not an easy task. Many societal and institutional factors (culture, history, welfare state, housing and credit markets, financial institutions, etc.) are likely to affect 
the wealth accumulation and portfolio choices of households. This section aims to shed some light on these potential sources of crosscountry heterogeneity. To this end we focus on real estate and risky financial assets and investigate the interactions between the estimated marginal effects of the key sociodemographic explanatory variables and some institutional factors 15 Our approach is similar to Christelis, Georgarakos, and Haliassos (2013), Bover et al. (this issue), and Le Blanc et al. (this issue). We estimate multivariate regressions where the estimated marginal effect of a given variable is regressed on a set of institutional variables 16 We choose to investigate the cross-country heterogeneity concerning the marginal effects of net wealth, income, age, education, and inheritances 17 on housing (section 5.1) and on risky financial assets (section 5.2).

\subsection{Cross-Country Differences in Real Estate Holdings}

The decision to hold real estate in general and a household main residence in particular results from a dual role of this asset for households: as a generator of housing services, housing satisfies consumption needs, and being an asset, it is also driven by investment decisions. In addition, housing wealth represents household debt collateral, as loans contracted for buying housing assets or for financing other needs (such as acquiring other assets or financing consumption spending) could be guaranteed by the value of the housing asset. This is why, when turning to cross-country comparisons, national specificities about the functioning of mortgage markets; housing market conditions (including transaction costs); wealth taxation; long-term financing needs, such as old-age expenses; or labor mobility are likely to affect household investment decisions concerning real estate via their impact on consumption or investment motives and via the collateral effect. These institutional factors may indeed induce the cross-country heterogeneity in the impact of the sociodemographic

\footnotetext{
${ }^{15}$ See appendix 6 for the definitions of the institutional indicators.

${ }^{16}$ Given the limited number of countries available in this analysis, one should interpret results with caution.

${ }^{17}$ These variables have been selected according to their significant estimated impacts obtained in the regressions, their relationship with the theoretical role for wealth accumulation and portfolio choices, and according to their potential interactions with institutional factors.
} 
determinants on real estate assets discussed in the previous section. We investigate this link between the institutional context and the cross-country heterogeneity in the estimated average marginal effects by regressing country-specific average marginal effects on institutional indicators related to the buy/rent trade-off, the mortgage market, and the wealth taxation. This analysis is done both for the household main residence and for other real estate.

\subsubsection{Mortgage Markets}

Household credit conditions vary across the euro area (Bover et al., this issue), and mortgage markets exhibit differences in many aspects (European Commission 2011). In particular, in some countries the use of mortgages to finance purposes other than acquiring the collateralized housing asset is widespread, while in other countries this phenomenon is very rare. According to the ECB (2009), the share of debt secured on housing assets used for purposes other than financing a new home varies from less than 1 percent in Luxembourg to 30 percent in Greece. We use this information as an indicator for the prevalence of the role of housing wealth as debt collateral (table 11 and table 12).

A negative cross-country correlation is obtained between this mortgage market indicator and the marginal effects of net wealth (fourth and fifth quintiles) on the portfolio share of the households' main residence. This result is consistent with the idea that the impact of net wealth (excluding HMR) on investment in HMR is less important in countries where households use contracted mortgages to finance other purposes. It could reflect differences in credit constraints faced by households with respect to home acquisitions (and potentially through differences in downpayment requirement, e.g., Chiuri and Jappelli 2003) and the financing of other spending (consumption, repayment of unsecured debt).

\subsubsection{Buy-Rent Trade-Off and Long-Term Financing Needs}

Obviously, the housing markets and the relative prices for buying versus renting could lead to cross-country heterogeneity in the participation and in the shares of the household main residence and housing assets. In particular, differences in these market conditions may induce cross-country heterogeneity in the estimated effects of 


\begin{tabular}{|c|c|c|c|}
\hline & 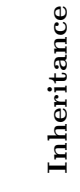 & 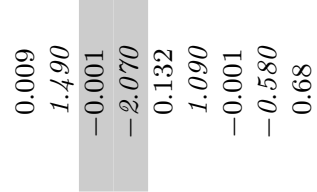 & 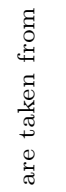 \\
\hline \multirow{2}{*}{$\stackrel{\infty}{40}$} & 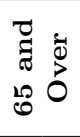 & 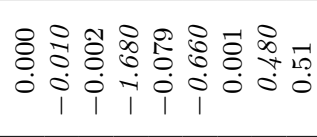 & 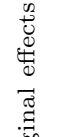 \\
\hline & $\begin{array}{l}\text { J゙ } \\
1 \\
0\end{array}$ & 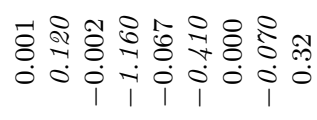 & 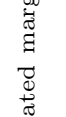 \\
\hline \multirow{4}{*}{ 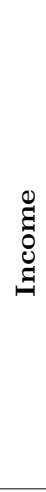 } & $\stackrel{10}{\sigma}$ & 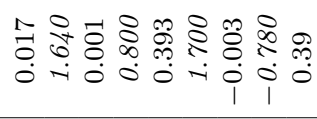 & 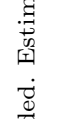 \\
\hline & $\stackrel{\not}{\sigma}$ & 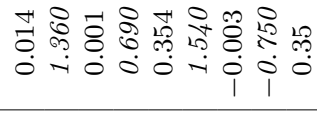 & 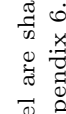 \\
\hline & $\ddot{\sigma}$ & 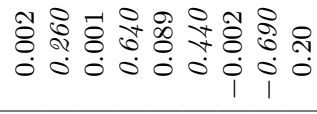 & 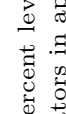 \\
\hline & ชี & 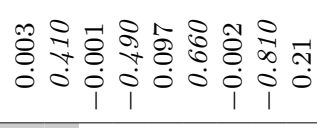 & 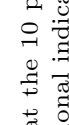 \\
\hline \multirow{4}{*}{ 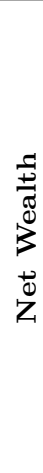 } & $\stackrel{10}{0}$ & 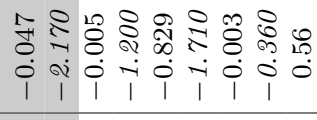 & 焉 \\
\hline & $\stackrel{\nabla}{\sigma}$ & 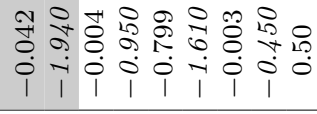 & 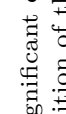 \\
\hline & $\ddot{\sigma}$ & 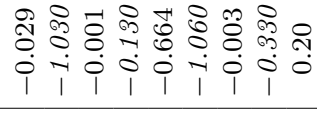 & 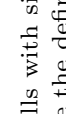 \\
\hline & ชี & 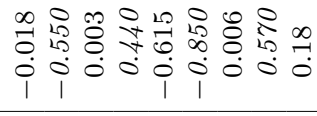 & $\begin{array}{cc}0 & 0 \\
0 & 0 \\
0 & 0 \\
0 & 0 \\
.0 & 0 \\
.0 & 0\end{array}$ \\
\hline & & 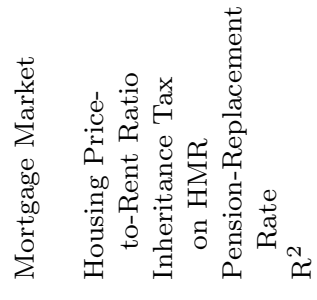 & 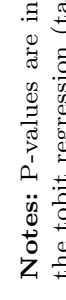 \\
\hline
\end{tabular}




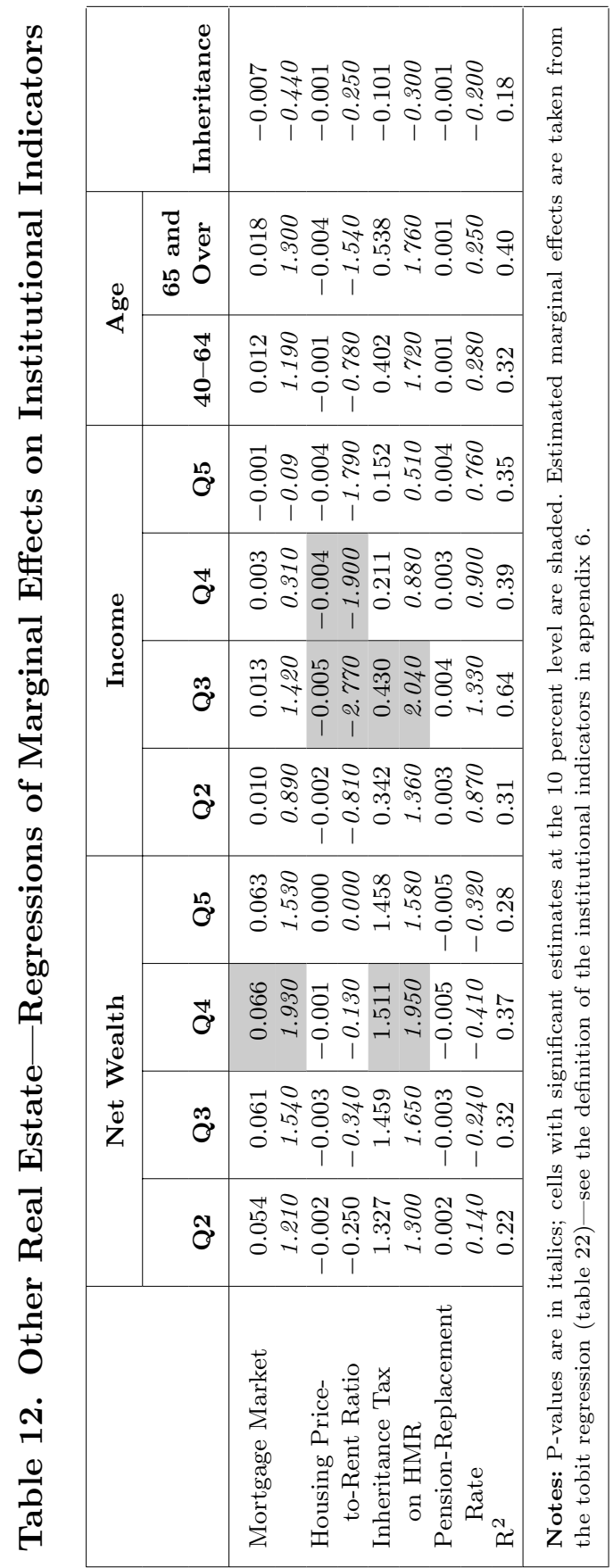


available household resources (e.g., income and wealth) on the decision to be or not to be a homeowner.

Another source for cross-country heterogeneity in the trade-off between renting versus buying could be the need to finance household consumption in old age. In that respect, one could expect that holding assets in the form of real estate is linked to expectations concerning the evolution of house prices and national features of the pension system.18 The diversity of national pension systems could lead to the very heterogeneous impacts of age on the portfolio share of the household main residence: a positive increasing effect, a hump-shaped profile, or a decreasing effect depending on the country (table 9).

We investigate these possible underlying factors leading to crosscountry differences in the tenancy choice trade-off by considering two indicators, the price-to-rent ratio and the average pension replacement rate, and their links with the determinants of the portfolio shares of the household main residence and other real estate (see tables 11 and 12).

For the portfolio share of other real estate, we find a negative correlation between the price-to-rent ratio and the marginal effects of income (which are estimated to be positive with large cross-country variation in the magnitude of the effects, except in Italy where the income levels are negatively related to the portfolio share of other real estate; see table 22). This could reflect that relative house prices are likely to influence households' investment decisions in housing assets in that an increase in the relative price-to-rent ratio decreases the rent yield and thus may reduce the incentive to invest in other real estate.

Concerning the determinants of the portfolio share of the household main residence, we find some weak indication (not significant) of a negative correlation between the price-to-rent ratio and age (sixty-five and above). This correlation with the age variable indicates that the life-cycle profile of housing wealth (main residence) in a country is related to its housing market conditions, and in particular to house prices; the higher the price-to-rent ratio, the later in life households will own their home. We do not obtain a significant correlation for the age profile of other real estate.

\footnotetext{
${ }^{18}$ One also could think about other institutional factors such as intergenerational cohabitation or housing equity withdrawal.
} 
The differences in correlations between the buy-to-rent ratio on the one hand and the age and income effects on the other hand across the two real estate portfolio shares considered (household main residence and other real assets) can probably be explained by the dual nature of housing assets, the household main residence being more related to housing consumption, and other real estate being more driven by investment decisions.

\subsubsection{Inheritance Tax on the Household Main Residence}

The regressions show that the magnitude of the marginal effect of net wealth on the portfolio share of housing assets is related to the existence of an inheritance tax on the household main residence. This effect is significant for other real estate; in countries where such a tax exists, the marginal effect of net wealth on the portfolio share of other real estate is higher. Concerning the share of the main residence, the relationship runs in the opposite direction (while not significant). It may reflect that in these countries, wealthy people tend to allocate their wealth in other assets than in the main residence, everything else being equal.

Finally, the negative correlation between the estimated average marginal effects of inheritances and the price-to-rent ratio is unexpected, because in the case of an increase in the price-to-rent ratio, we would have expected a larger positive impact of having past intergenerational transfers on holding of the HMR.

\subsection{Cross-Country Differences in Risky Financial Assets Holding}

Institutional factors are also likely to affect households' decisions to invest in risky financial assets. In particular, one could suspect that cross-country heterogeneity in the households' capacities to gather and process financial information, local firms' demand for long-term financing, or the existence of country-specific factors affecting risk perceptions and expectations at the household level could induce heterogeneity in the estimated marginal effects of the sociodemographic variables (table 10). Regressions of the estimated average marginal effect of net wealth, income, education, and inheritances on various institutional factors are provided in table 13 . 


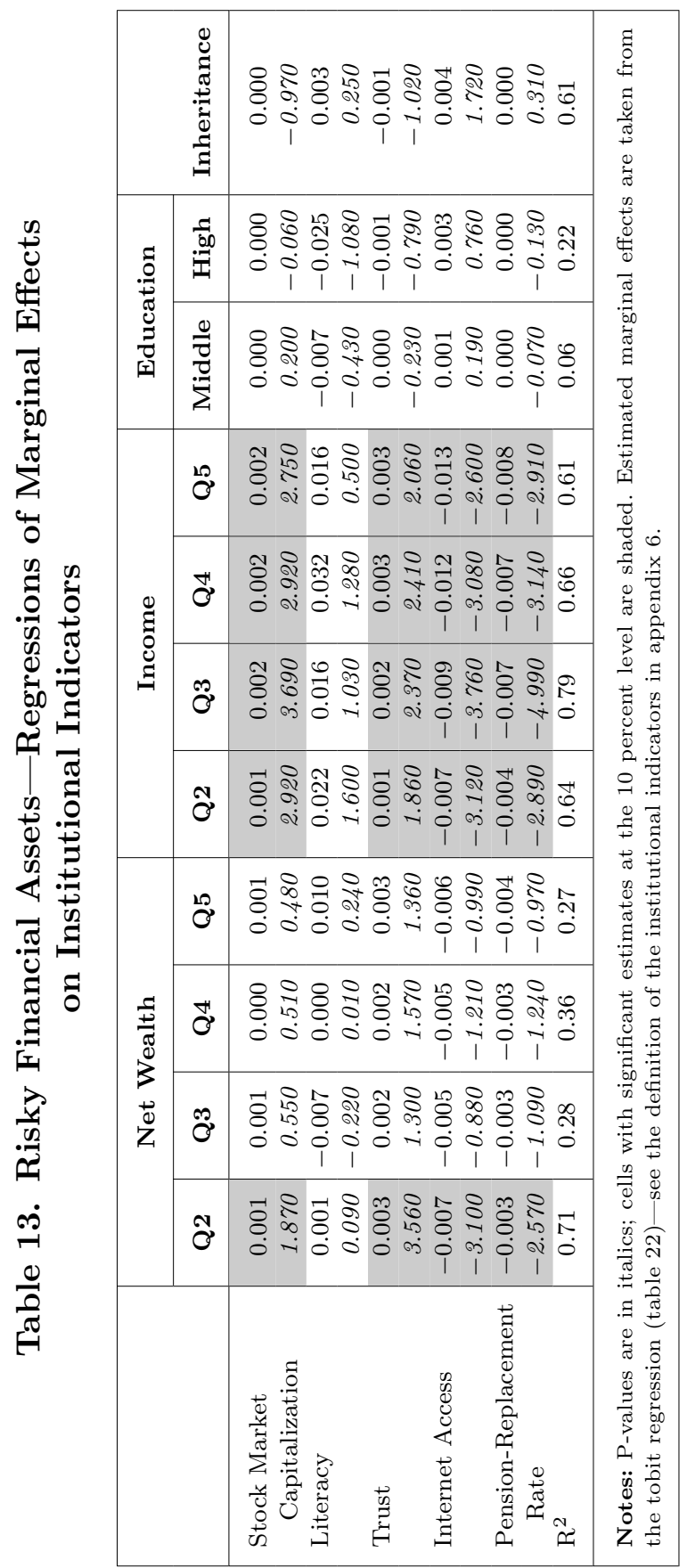


There is a positive interaction between the stock market capitalization in the country and the income marginal effect on the portfolio share invested in risky financial assets. Such a result may reflect a supply effect arising from the financial environment.

We find evidence of a negative cross-country correlation between the share of households with Internet access and the average marginal effects of the controls for the position of the household in the net wealth and income distributions. These results are consistent with the idea that better access to information lowers the entry and transaction costs so that households' own resources play a less important role for the holding of risky financial assets.

The regressions also show that the magnitude of the positive income effect on the portfolio share of risky financial assets varies negatively with the average pension replacement rate, which could reflect that, in countries with a high replacement rate, households are less incited to invest in long-term assets.

In addition, consistent with results reported by Guiso, Sapienza, and Zingales (2008), there is a positive correlation between the level of trust in the country and the positive income and wealth effects on the portfolio share of risky assets.

\section{Conclusions}

This paper provides stylized facts on the asset composition of households in the euro area. The heterogeneity across euro-area countries is sizable across a number of dimensions, such as income and wealth.

Whereas ownership of the household main residence varies strongly between countries, the value of the main residence is the main asset for those who own it and it represents a significant part of total assets in all countries, including those with relatively low ownership rates. The vast majority of total assets consist of real assets. With regard to financial assets, almost all households hold safe assets, such as deposit or savings accounts, while a rather low share of households holds risky assets, such as stocks, bonds, and mutual funds. 
The ownership rates of all asset categories generally increase with households' position in the net wealth and income distribution. Ownership rates of safe financial assets are uniformly high across all euro-area countries. They diverge substantially for ownership of the household main residence. Especially the share of risky financial asset holders rises sharply with the position of the household in the net wealth distribution but stays surprisingly low even for households in the highest net wealth deciles. The significance of inheritances for the wealth accumulation process is remarkable.

Although our stylized facts are derived from survey data obtained in a high-turmoil period (2010-11), we believe they are related to structural factors of asset holdings that are not so much varying over the cycle. A joint analysis of structural determinants and factors that vary over the business cycle will become possible when more waves of the survey become available.

Our analysis of the relationship between institutions and the impact of sociodemographics on asset holdings indicates that institutional factors can moderate the impact of some household characteristics on households' portfolio choices in different countries. Investigating institutional factors in more detail-in particular, uncovering the mechanisms of how they affect portfolio choices - is a promising avenue for future research. The particularly large heterogeneity in homeownership rates across the euro area seems an area worth further research (see, for example, Mathä, Porpiglia, and Ziegelmeyer 2014). House price developments and mortgage indebtedness were key factors in the financial crisis, so homeownership has important macroeconomic implications. Public policies such as mortgage interest tax deductibility, subsidized housing, rent policies, taxation on house-buying transactions, and inheritance tax on homes are not only substantially different across countries but are also factors that are likely to shape financial decisions of households. Disentangling the effects of a multitude of policies on household asset holding choices in a number of ways is certainly not easy. As more household wealth survey data become available, one can hope that the role of public policies can be more vigorously investigated. 


\section{Appendix 1. Results on the Extensive and} Intensive Margin

Table 14. Participation Rates for Asset Categories, in \%

\begin{tabular}{|l|c|c|r|r|c|}
\hline & HMR & ORE & BUS & SAFE & RISKY \\
\hline Euro Area & 60.1 & 23.8 & 11.1 & 96.7 & 20.2 \\
Austria & 47.7 & 13.4 & 9.4 & 99.4 & 14.6 \\
Belgium & 69.6 & 16.4 & 6.6 & 97.9 & 30.7 \\
Cyprus & 76.7 & 51.6 & 19.5 & 85.9 & 36.3 \\
Germany & 44.2 & 17.8 & 9.1 & 99.1 & 23.0 \\
Spain & 82.7 & 36.2 & 14.2 & 98.2 & 14.0 \\
Finland & 69.2 & 29.8 & 13.8 & 100.0 & 38.7 \\
France & 55.3 & 28.5 & 8.9 & 99.6 & 21.7 \\
Greece & 72.4 & 37.9 & 9.8 & 73.9 & 4.0 \\
Italy & 68.7 & 24.9 & 18.0 & 91.9 & 19.8 \\
Luxembourg & 67.1 & 28.2 & 5.2 & 98.4 & 25.8 \\
Malta & 77.7 & 31.4 & 11.5 & 96.9 & 33.7 \\
Netherlands & 57.1 & 6.1 & 4.8 & 97.3 & 23.9 \\
Portugal & 71.5 & 27.1 & 7.7 & 94.3 & 6.5 \\
Slovenia & 81.8 & 23.2 & 11.6 & 93.6 & 20.3 \\
Slovakia & 89.9 & 15.3 & 10.7 & 91.5 & 4.1 \\
\hline Source: HFCS 2013. & \multicolumn{5}{l}{} \\
Notes: HMR: household main residence, ORE: other real estates, BUS: self- \\
employment business, SAFE: safe financial assets, RISKY: risky financial assets. \\
1Finland collects information on BUS only in a summarizing way; estimates are not \\
comparable.
\end{tabular}


Table 15. Conditional Median of Asset Categories, in EUR Thousands

\begin{tabular}{|c|c|c|c|c|c|c|}
\hline & HMR & ORE & BUS & SAFE & RISKY & TOTAL \\
\hline Euro Area & 180.3 & 100.0 & 30.0 & 9.2 & 12.1 & 142.0 \\
\hline Austria & 200.0 & 94.0 & 180.6 & 11.9 & 12.3 & 92.8 \\
\hline Belgium & 250.0 & 174.0 & 50.0 & 20.7 & 20.1 & 249.9 \\
\hline Cyprus & 240.3 & 202.2 & 98.8 & 18.3 & 2.0 & 331.9 \\
\hline Germany & 168.0 & 115.0 & 19.4 & 13.2 & 12.1 & 67.9 \\
\hline Spain & 180.3 & 120.2 & 50.8 & 5.1 & 12.0 & 210.2 \\
\hline Finland $^{1}$ & 127.8 & 107.6 & 0.9 & 5.7 & 3.7 & 132.7 \\
\hline France & 193.8 & 96.1 & 53.1 & 8.9 & 8.1 & 150.4 \\
\hline Greece & 100.0 & 61.9 & 36.2 & 3.9 & 7.3 & 110.2 \\
\hline Italy & 200.0 & 100.0 & 15.0 & 7.4 & 22.4 & 188.0 \\
\hline Luxembourg & 500.0 & 300.0 & 97.6 & 23.1 & 28.5 & 494.4 \\
\hline Malta & 186.6 & 120.1 & 136.5 & 17.7 & 21.6 & 227.4 \\
\hline Netherlands & 240.0 & 165.5 & 51.7 & 30.4 & 8.2 & 217.3 \\
\hline Portugal & 90.0 & 53.5 & 47.1 & 3.8 & 8.9 & 93.2 \\
\hline Slovenia & 110.9 & 52.4 & 25.5 & 1.1 & 3.4 & 105.2 \\
\hline Slovakia & 55.9 & 16.4 & 4.6 & 2.3 & 1.1 & 64.4 \\
\hline \multicolumn{7}{|c|}{$\begin{array}{l}\text { Source: HFCS } 2013 . \\
\text { Notes: HMR: household main residence, ORE: other real estates, BUS: self- } \\
\text { employment business, SAFE: safe financial assets, RISKY: risky financial assets. } \\
{ }^{1} \text { Finland collects information on BUS only in a summarizing way; estimates are not } \\
\text { comparable. }\end{array}$} \\
\hline
\end{tabular}


Vol. 12 No. 2 How Do Households Allocate Their Assets?

175

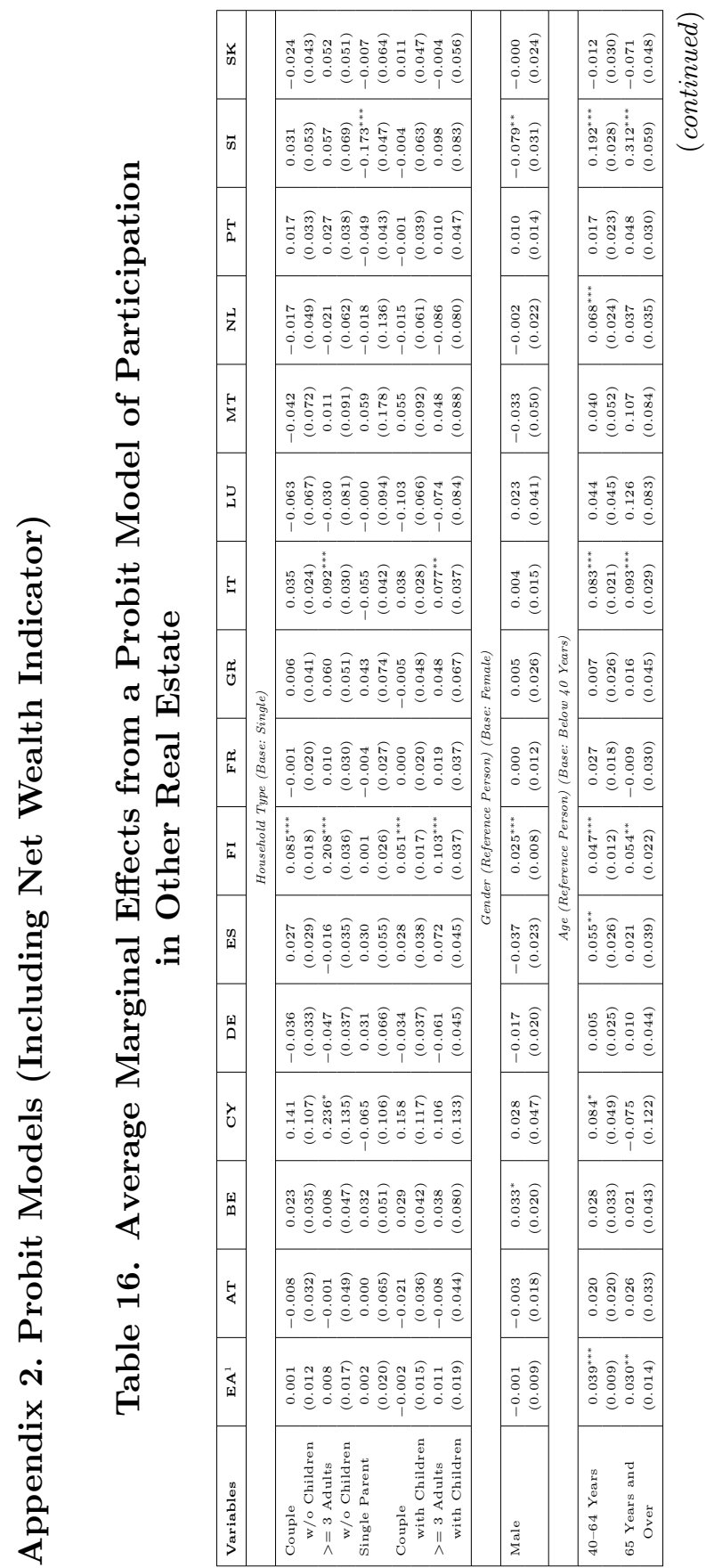




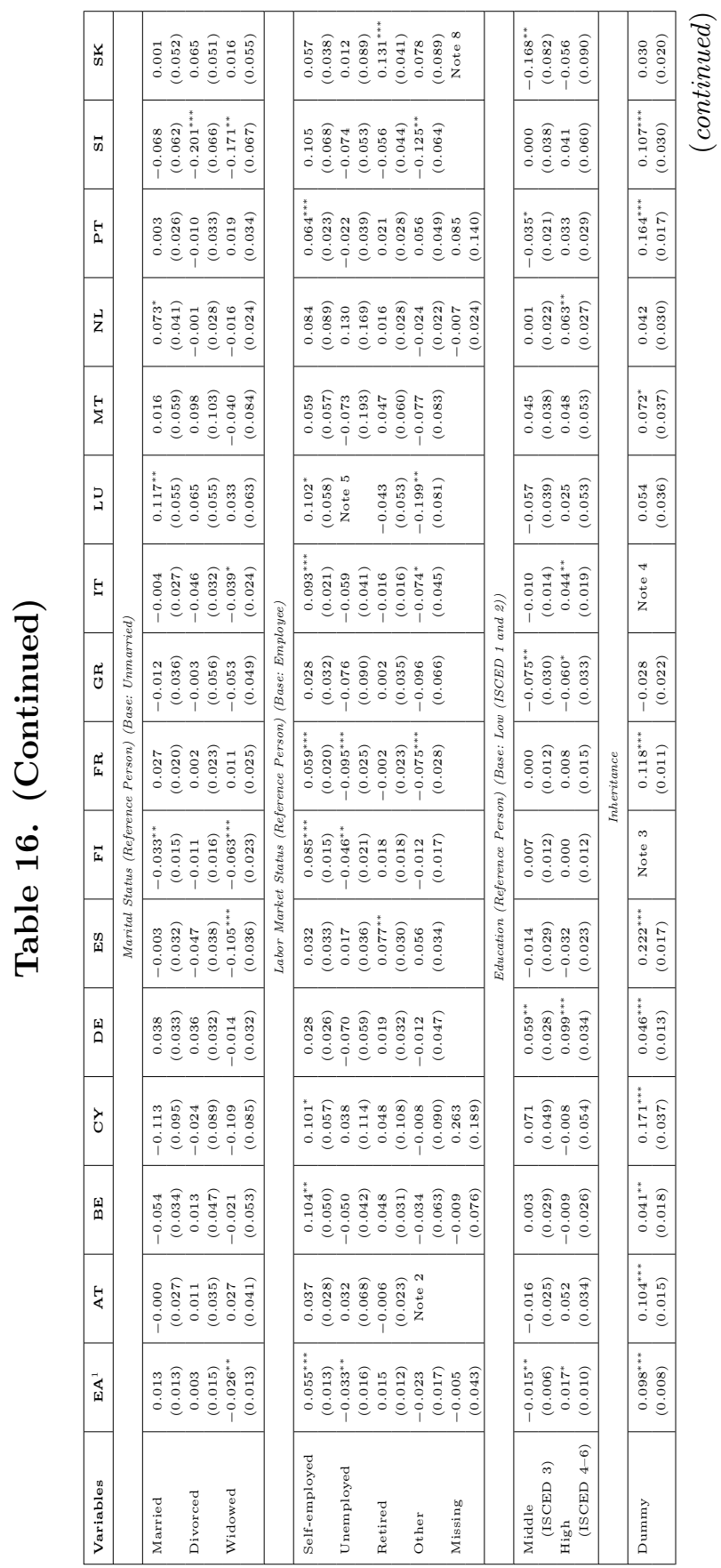




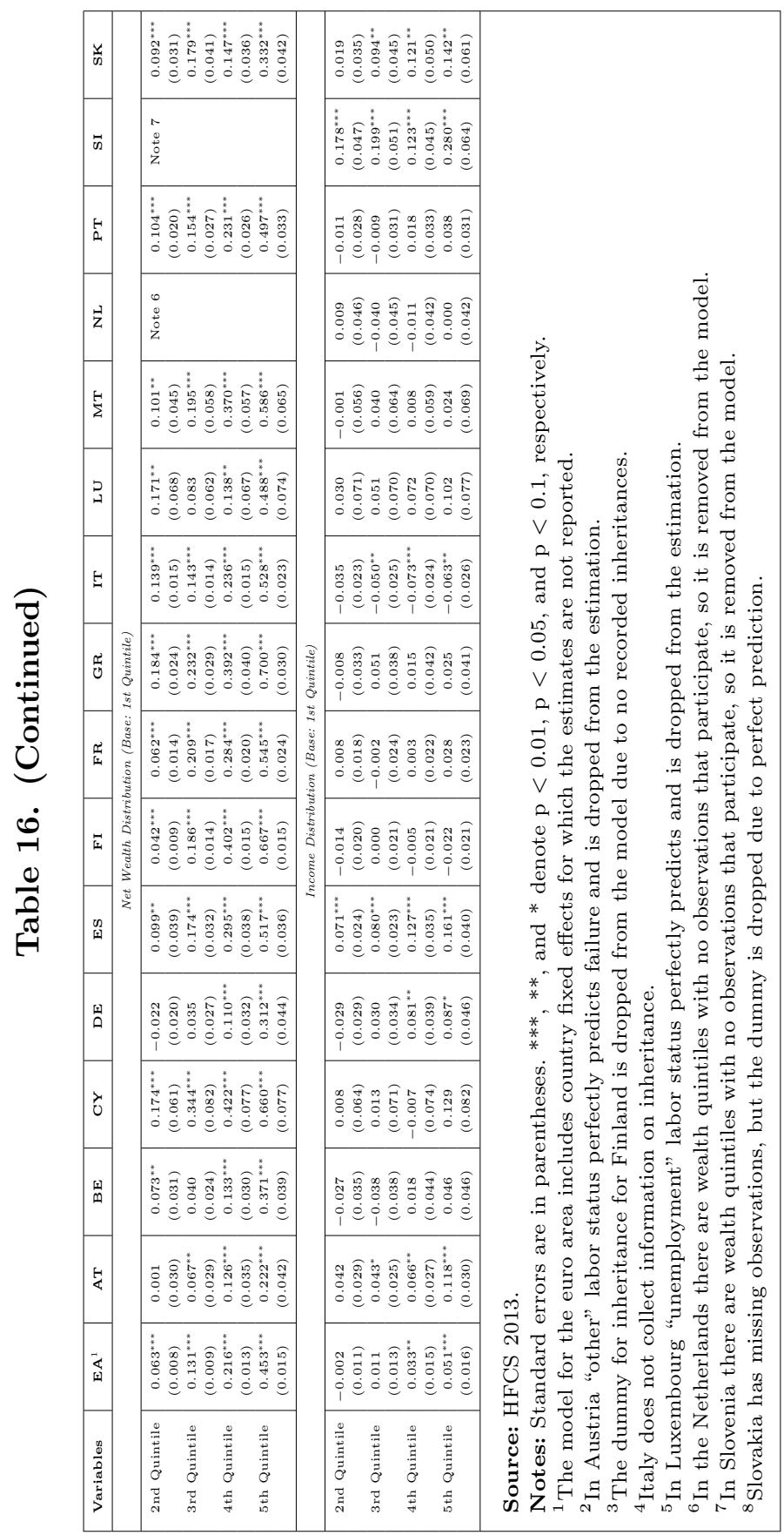




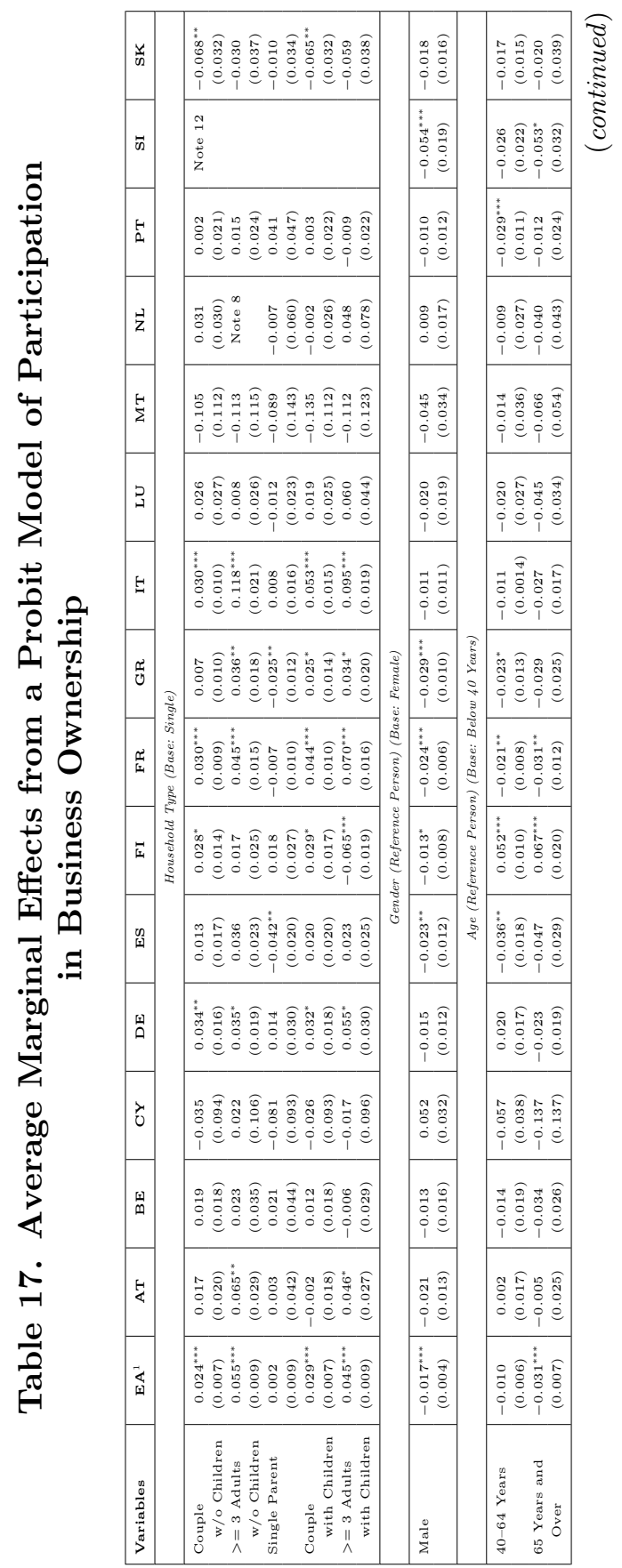




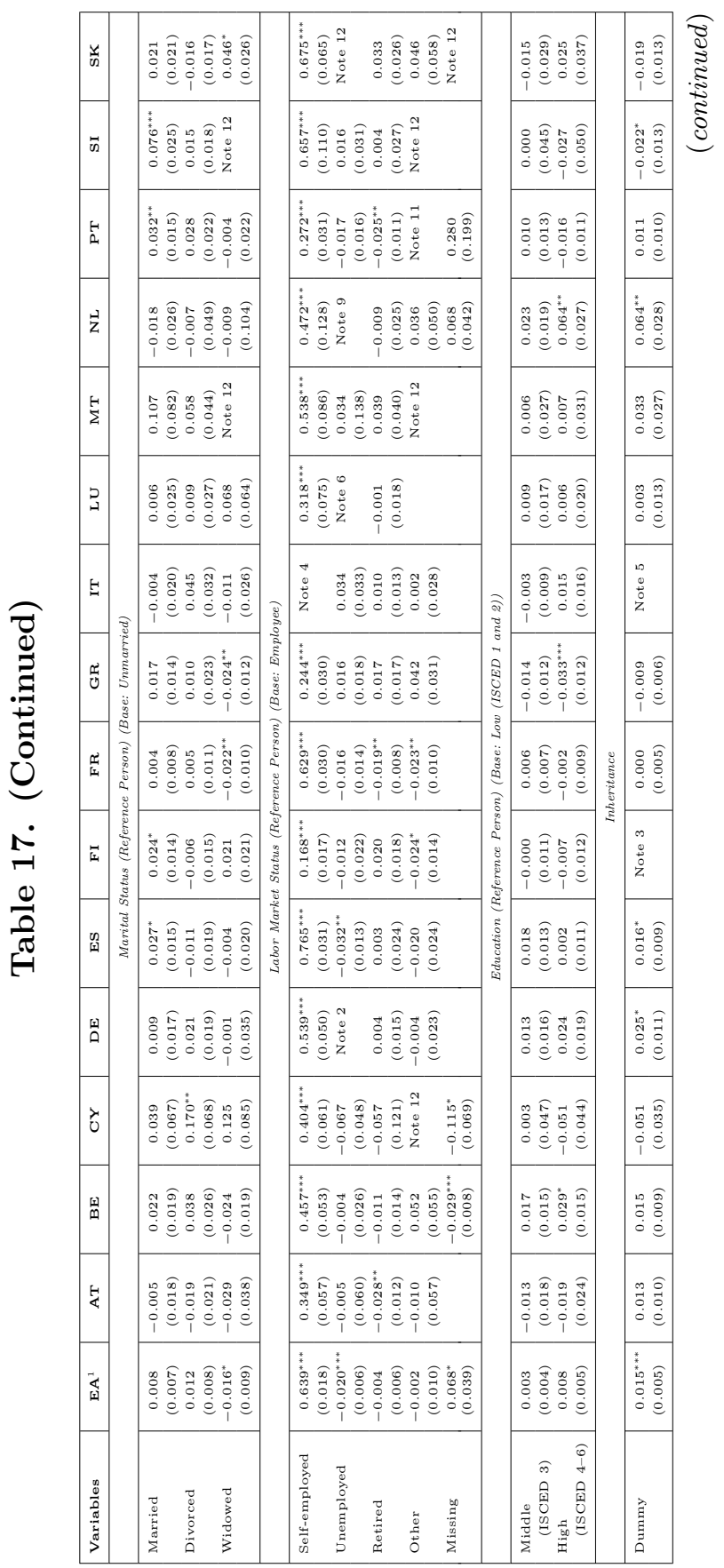




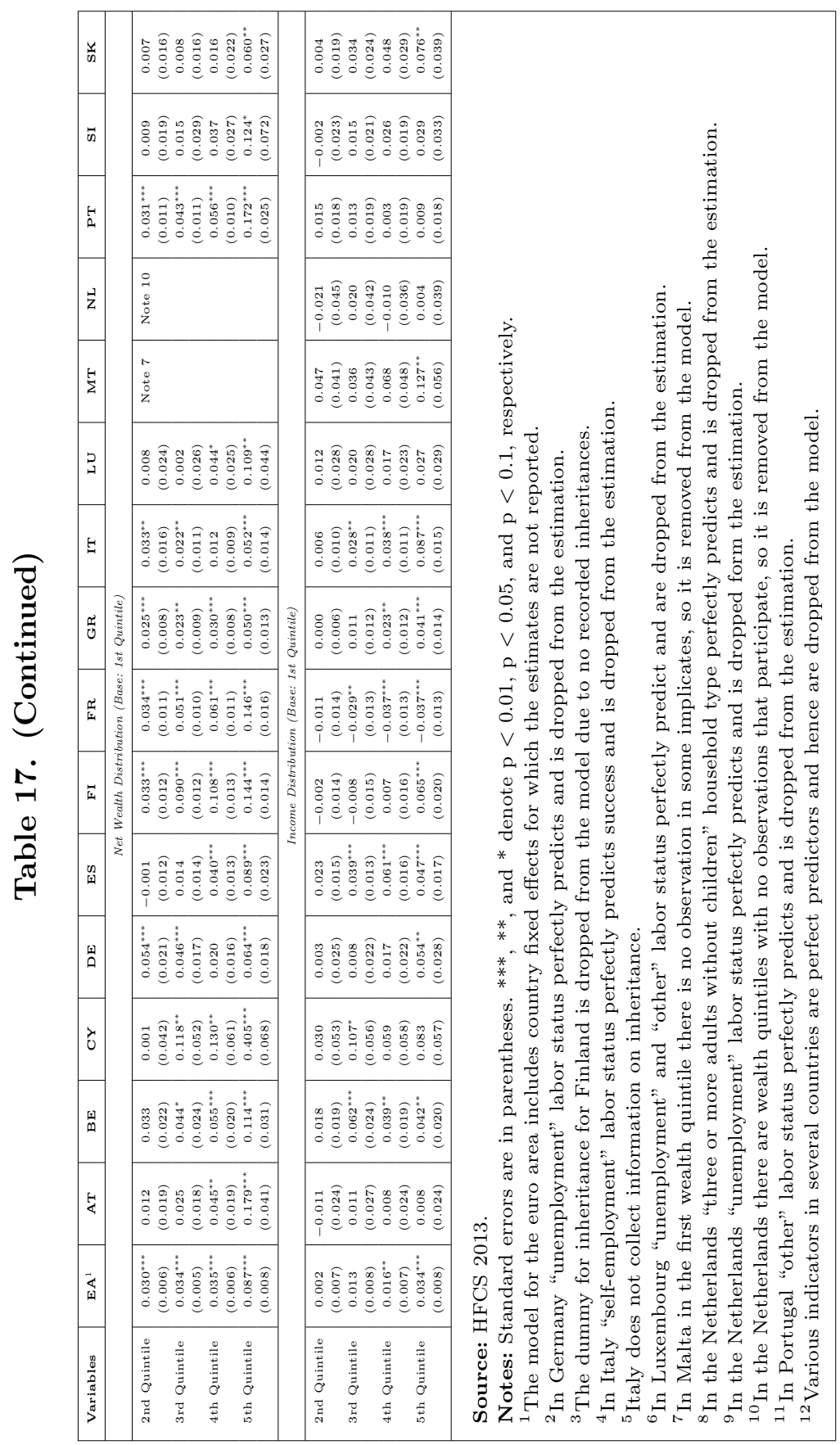


Vol. 12 No. 2 How Do Households Allocate Their Assets?

181

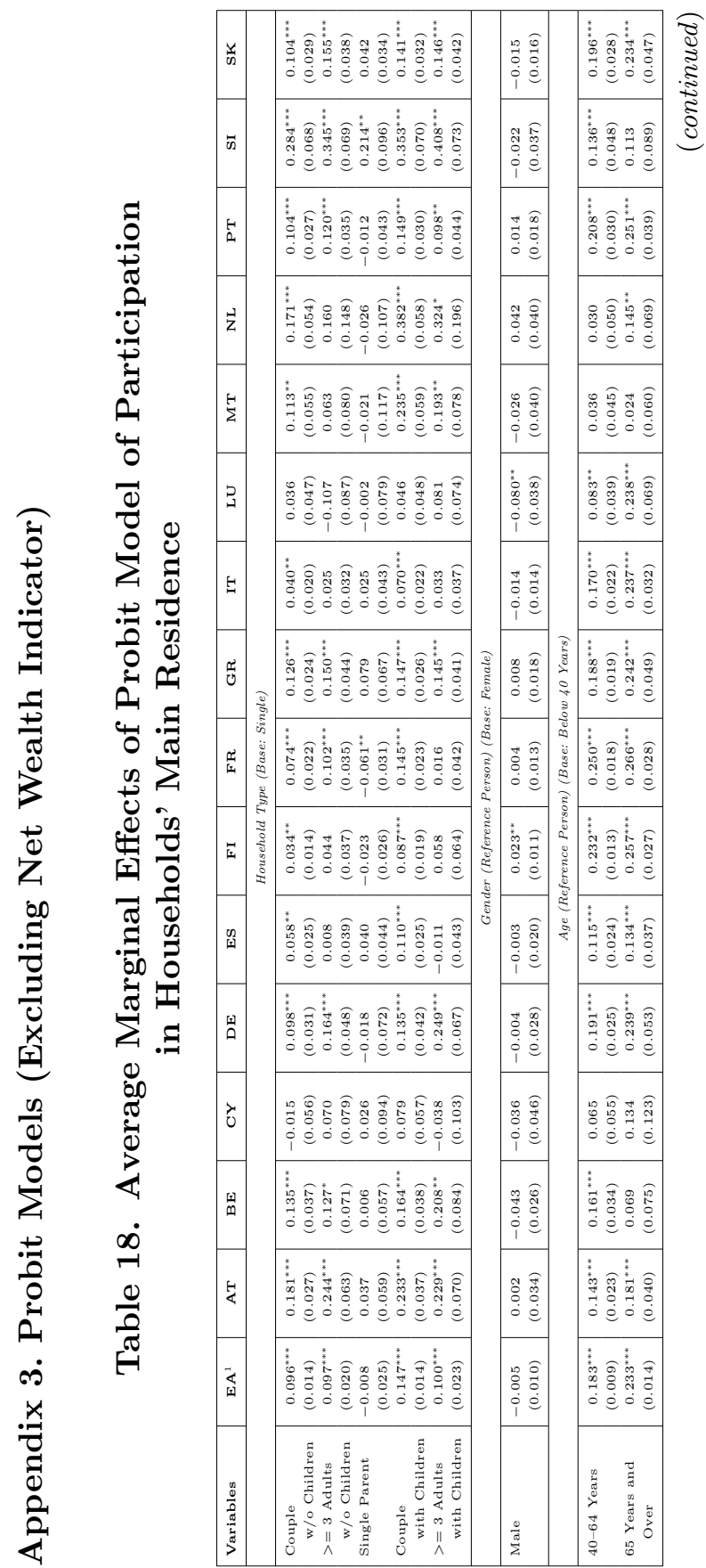




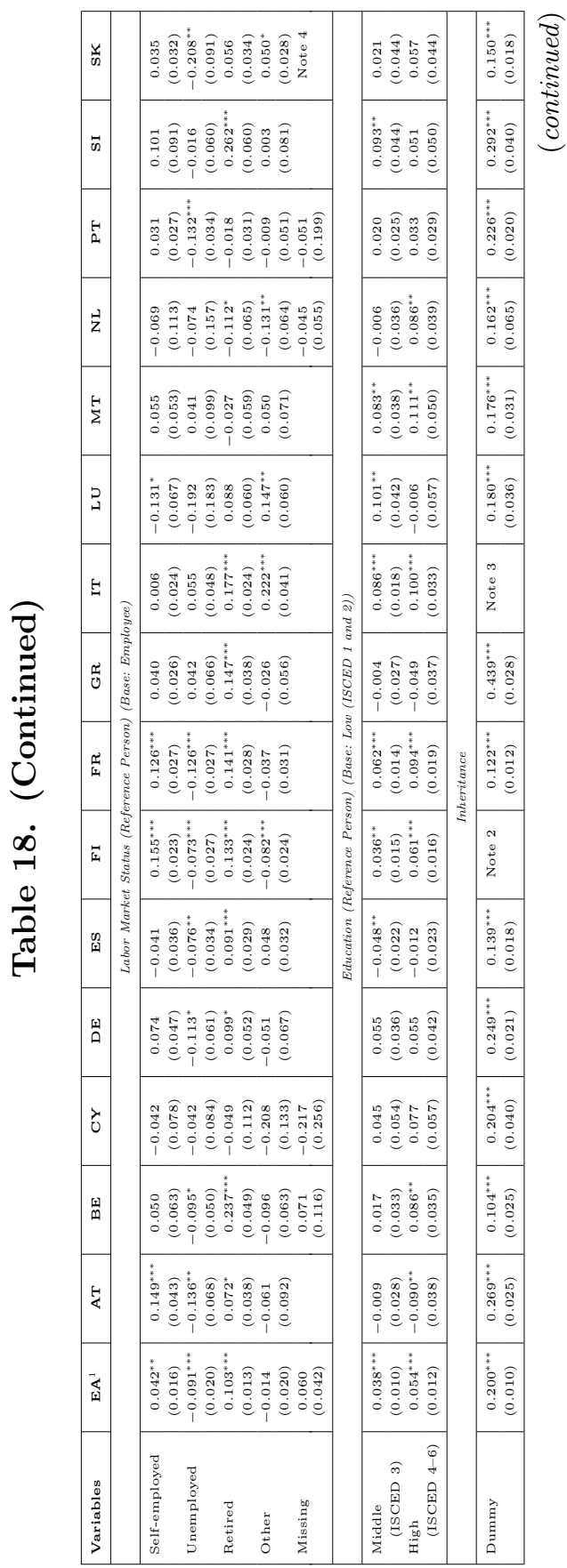


Vol. 12 No. 2

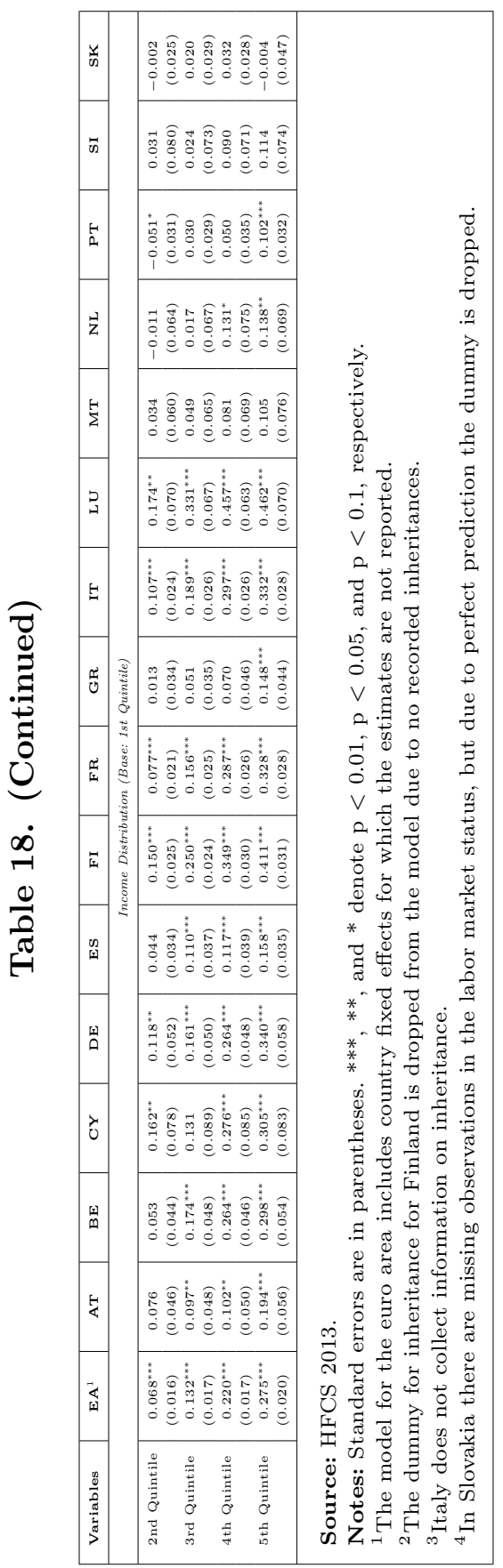




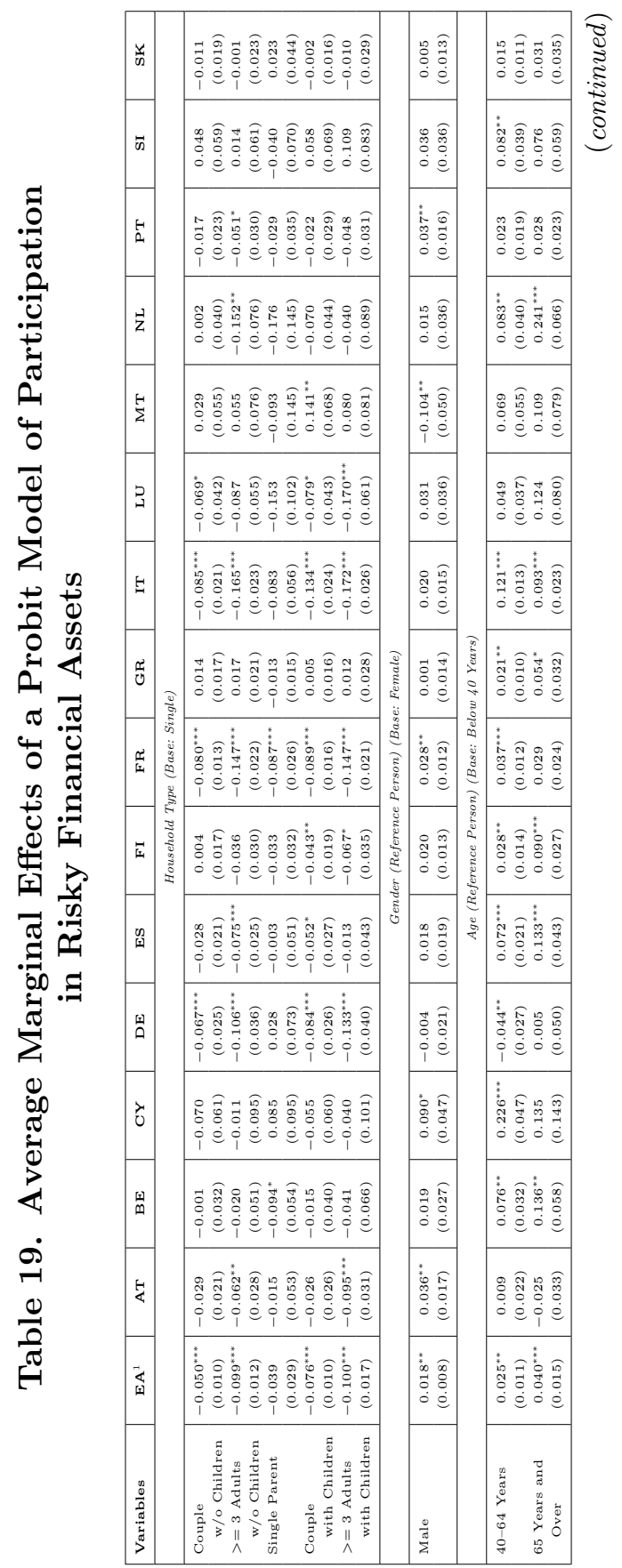


Vol. 12 No. 2

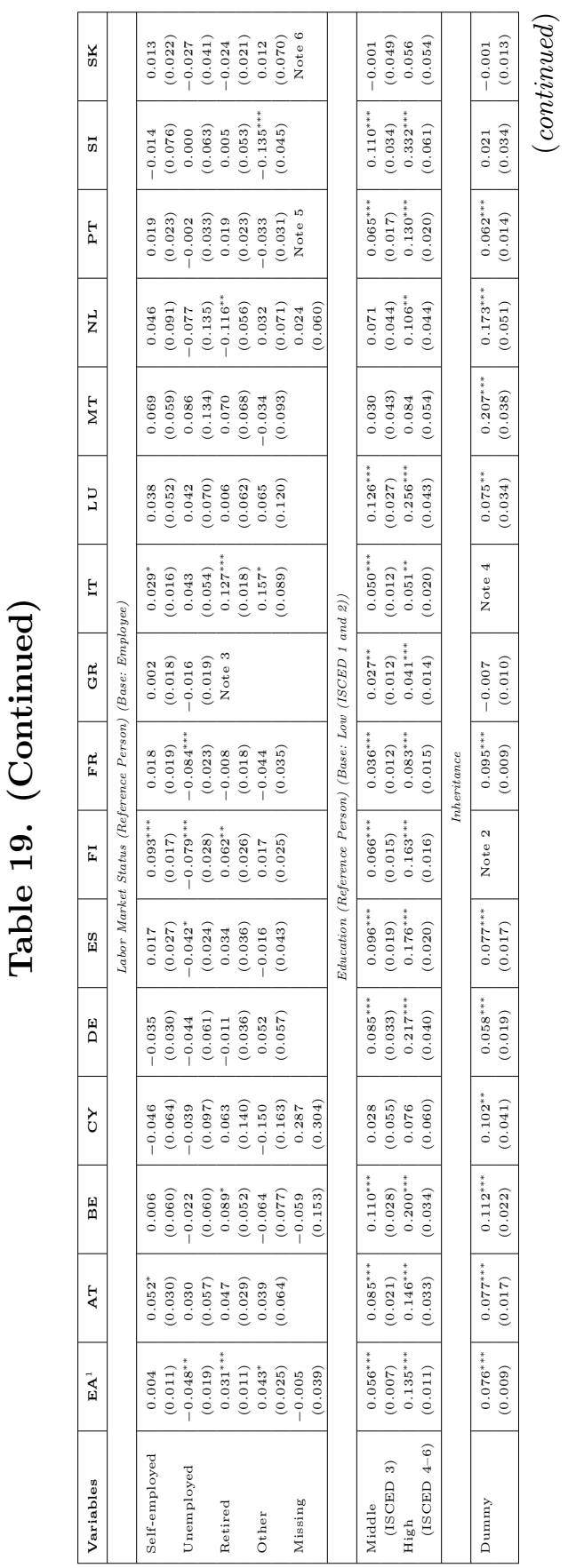




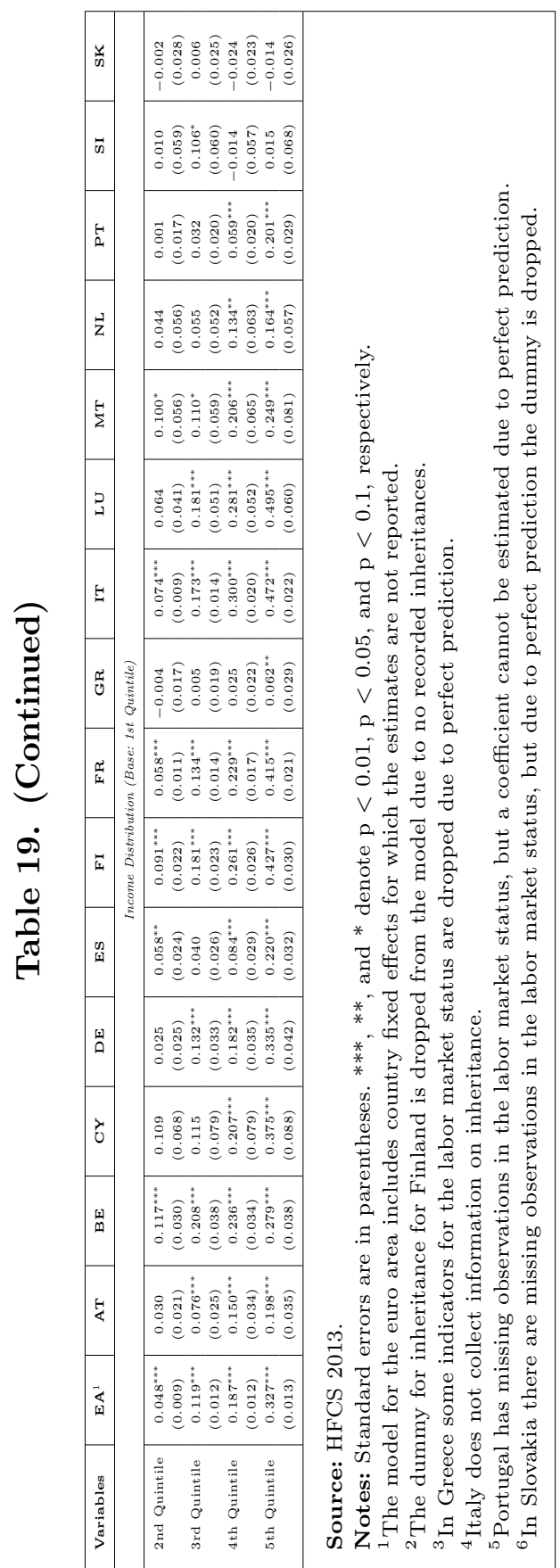




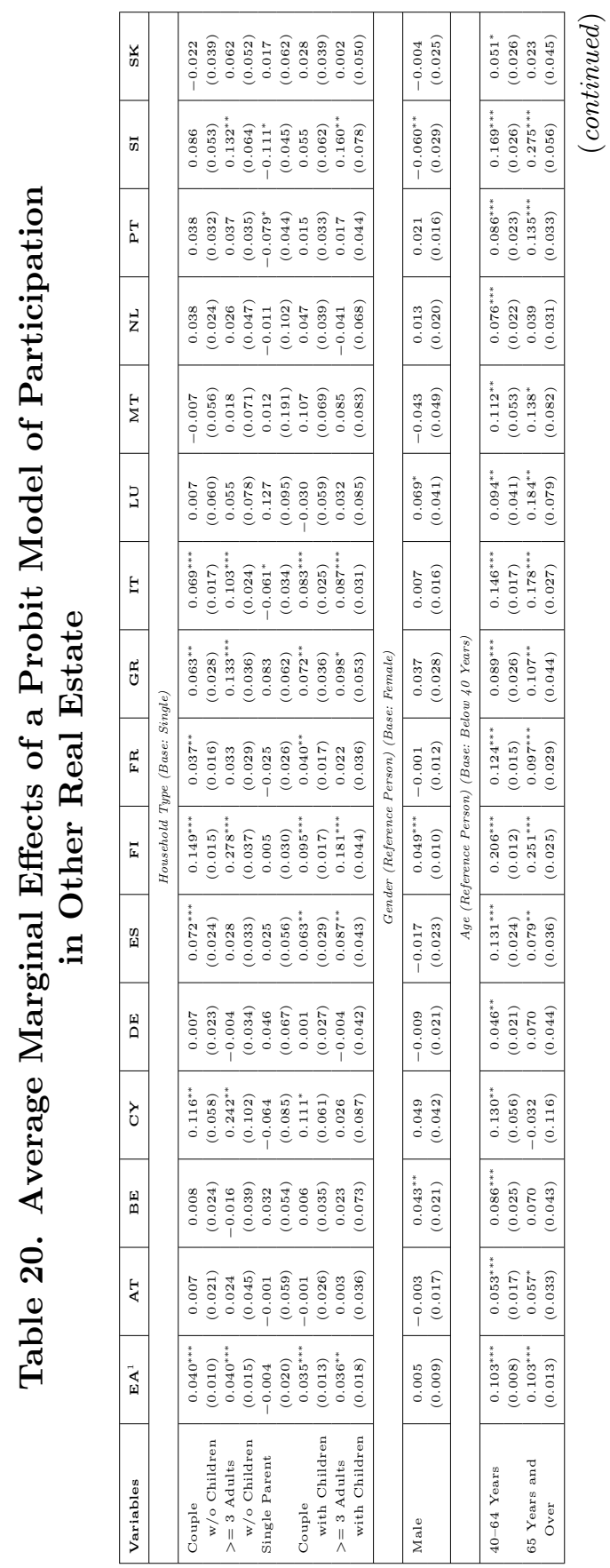




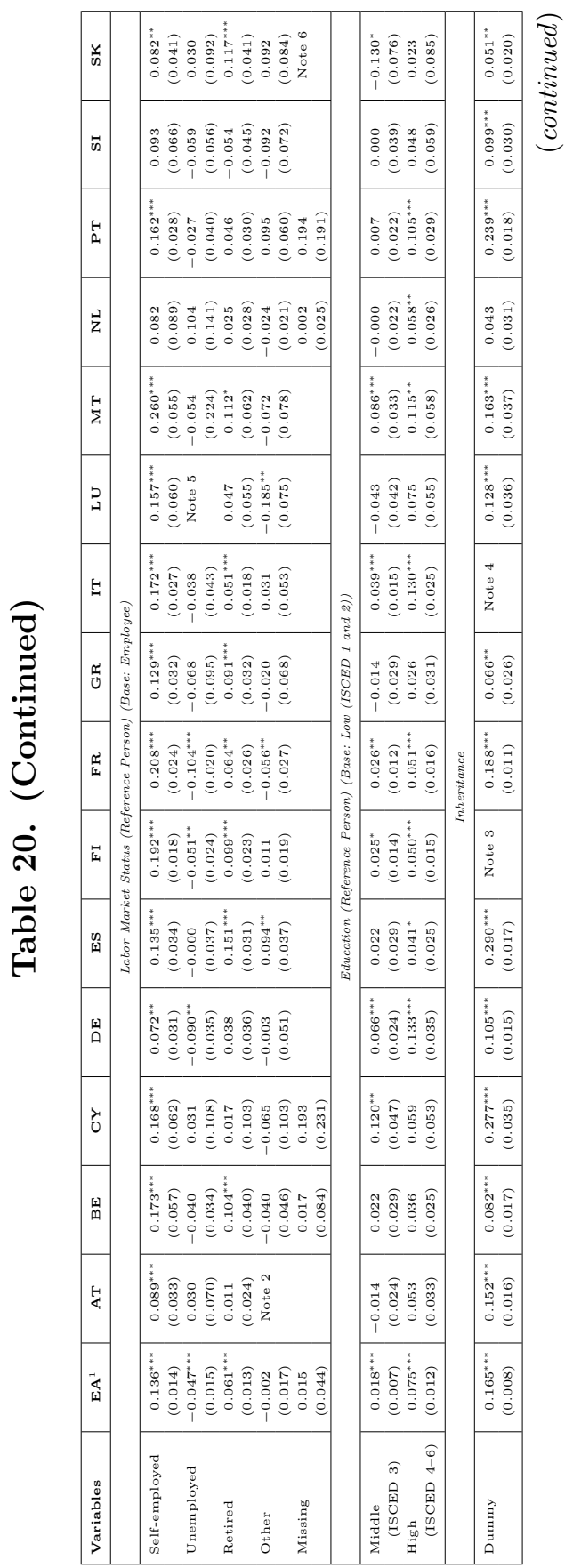


Vol. 12 No. 2

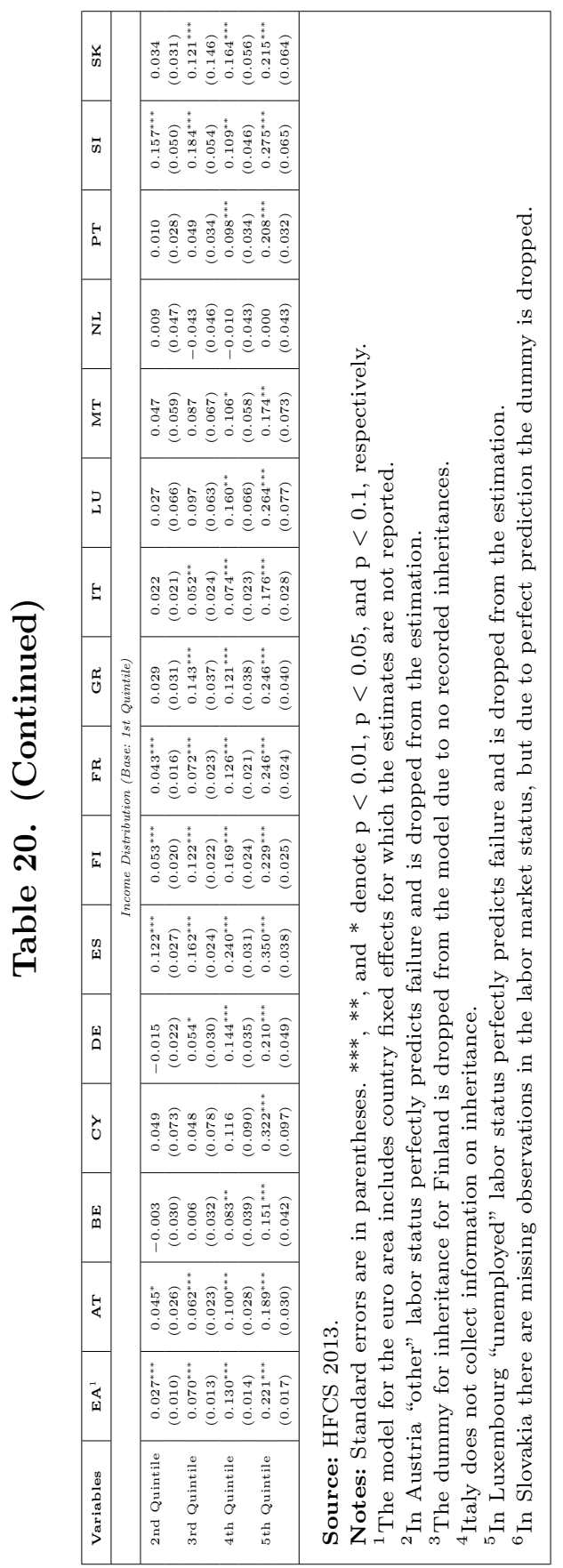




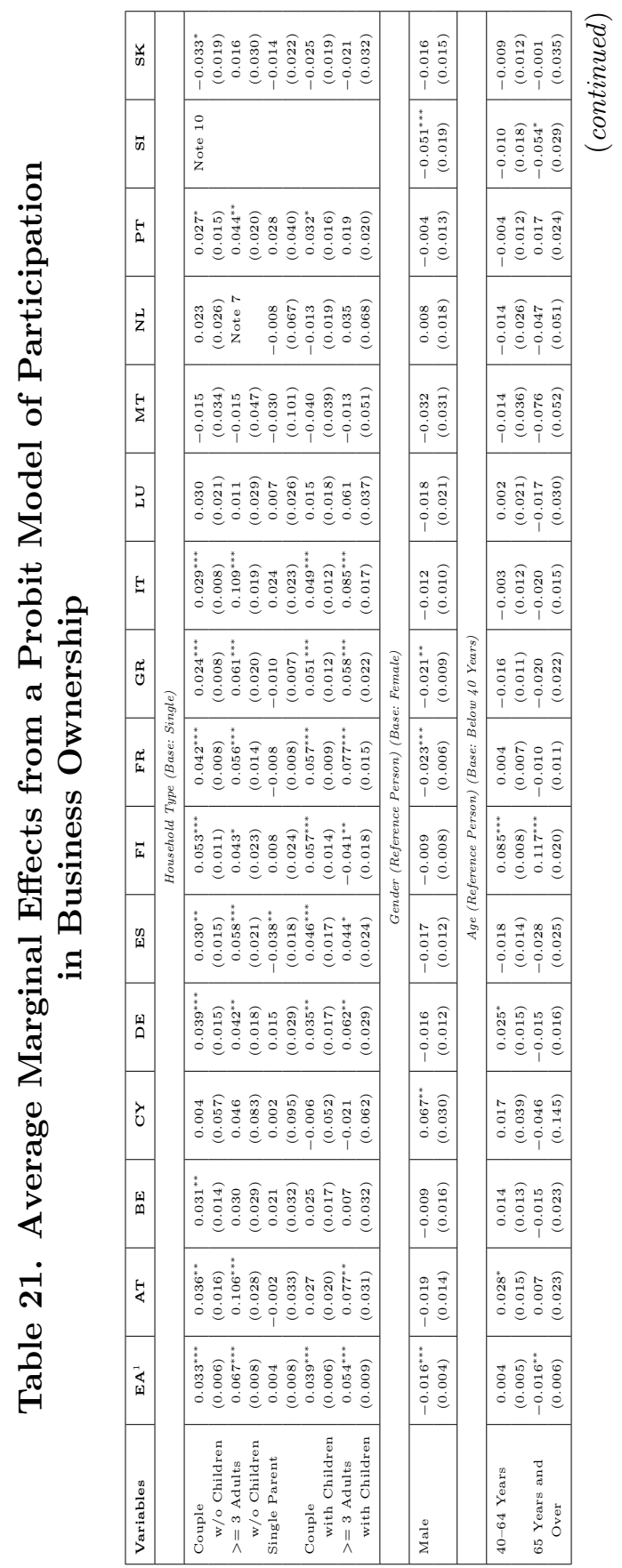


Vol. 12 No. 2

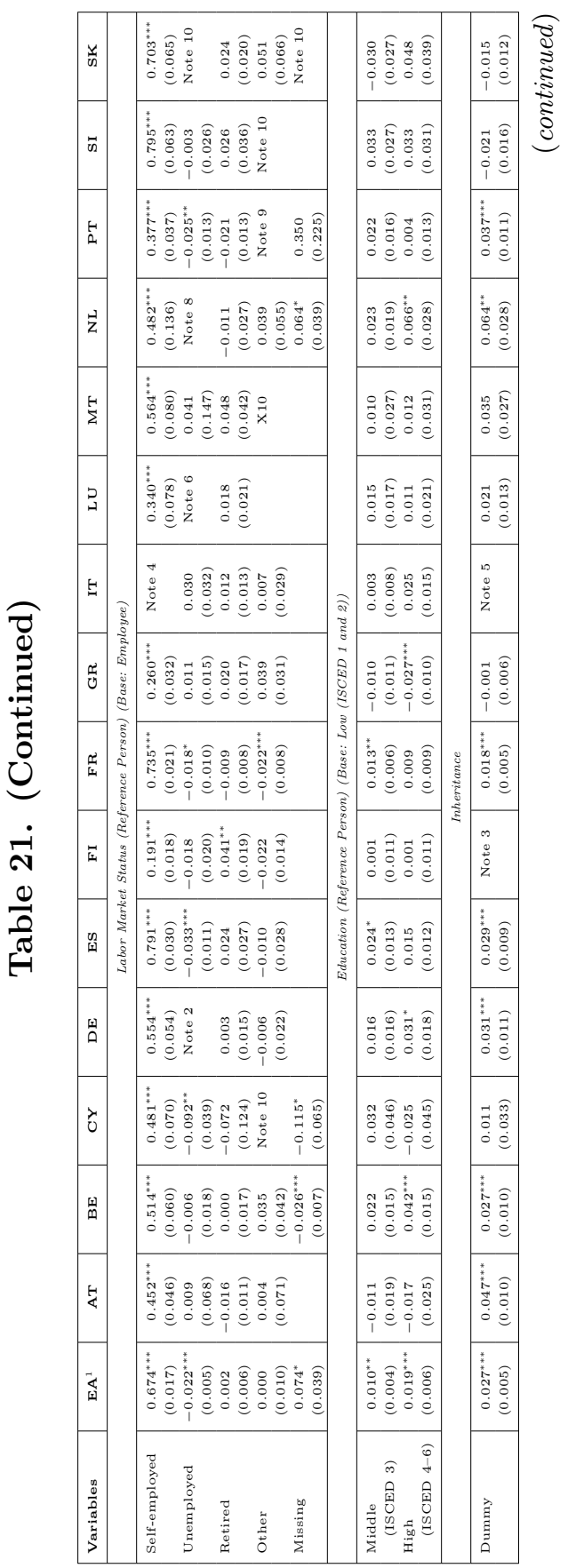




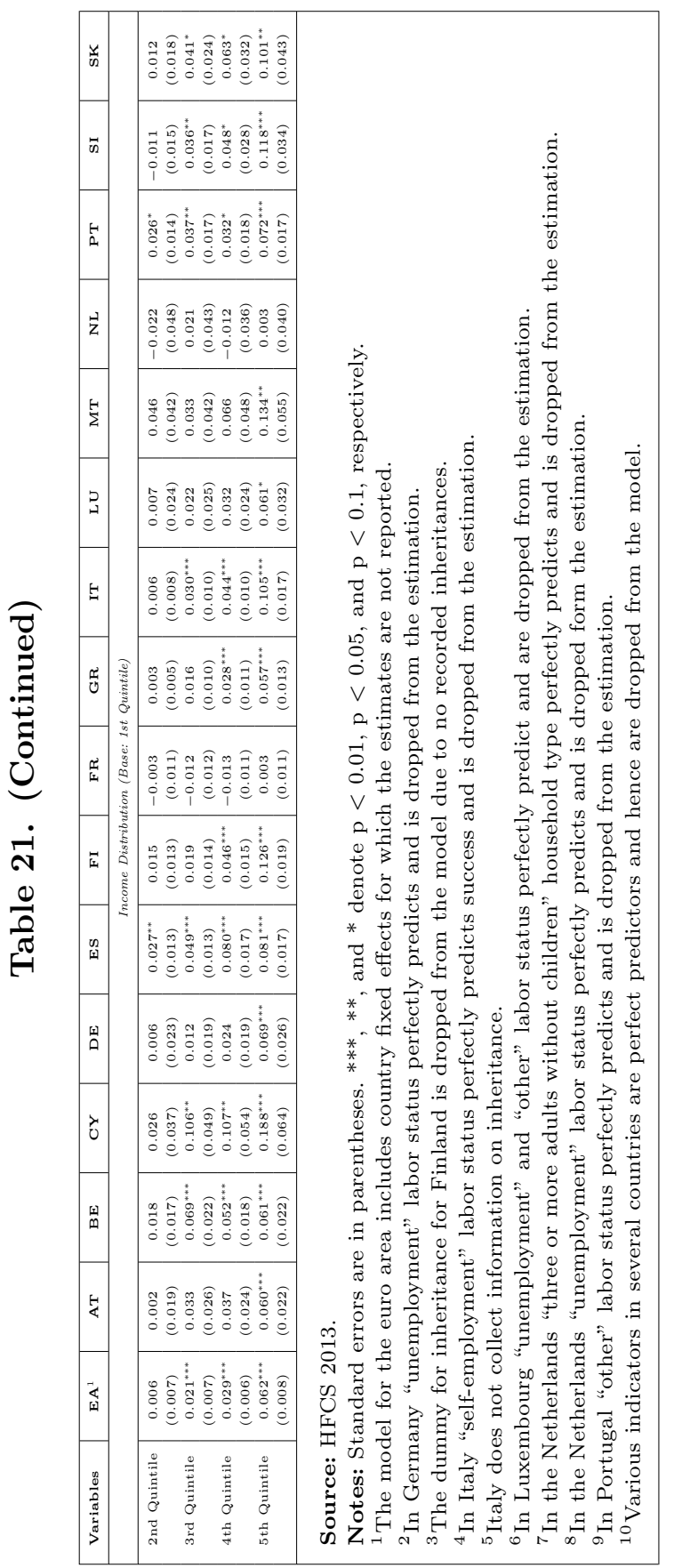


Vol. 12 No. 2 How Do Households Allocate Their Assets?

193

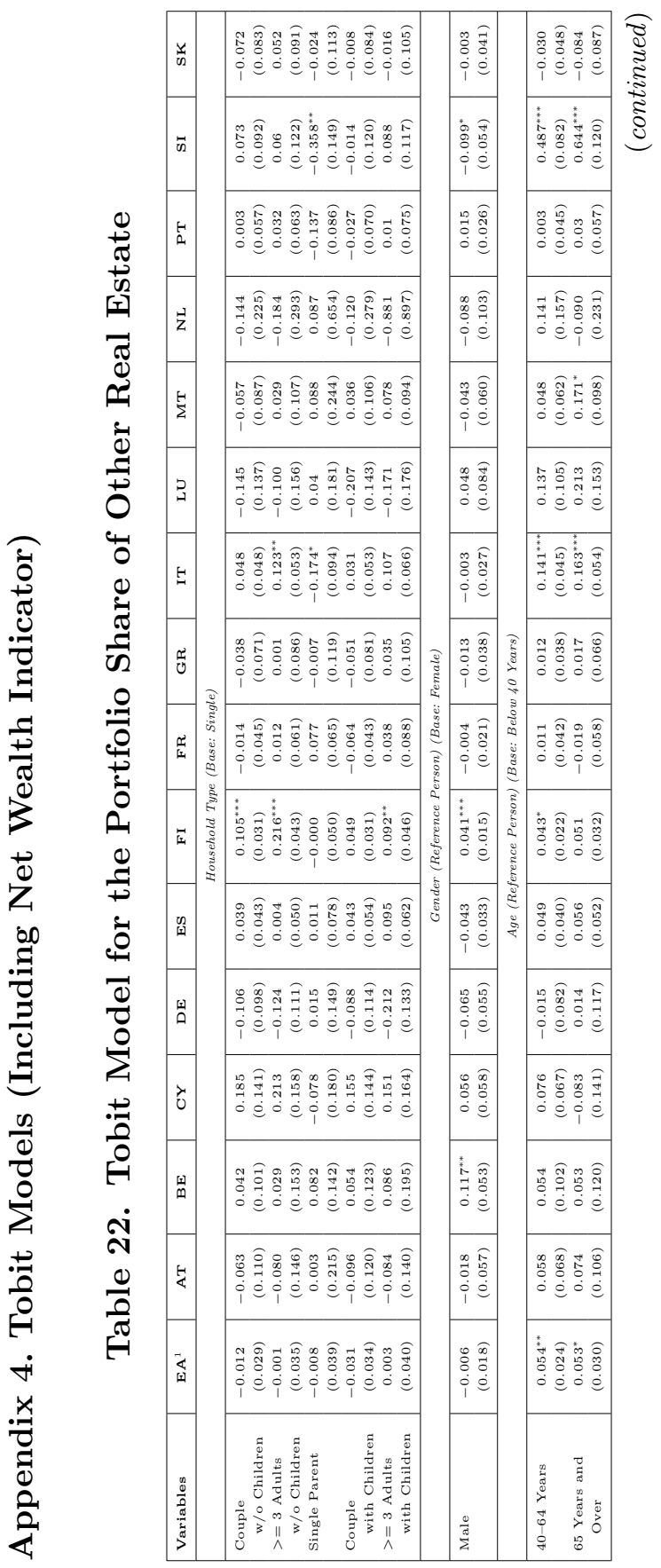




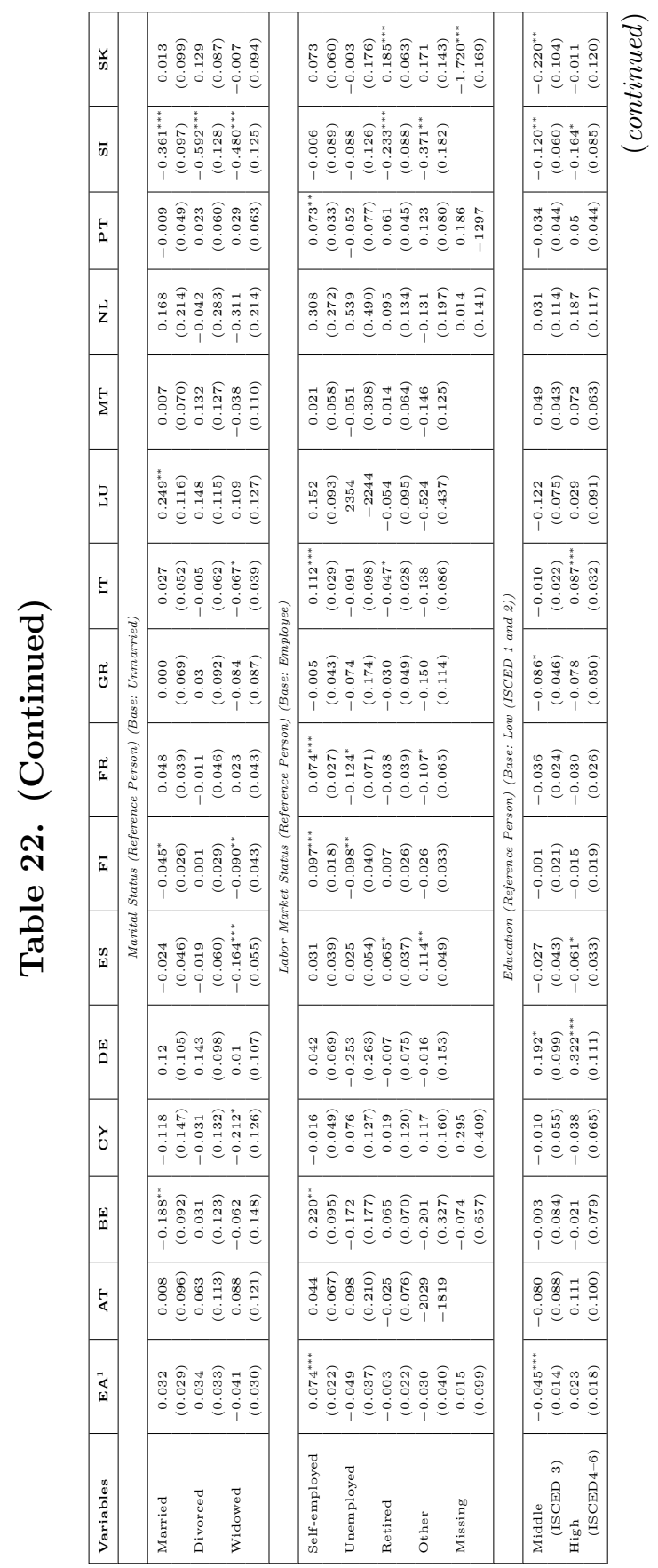


Vol. 12 No. 2 How Do Households Allocate Their Assets?

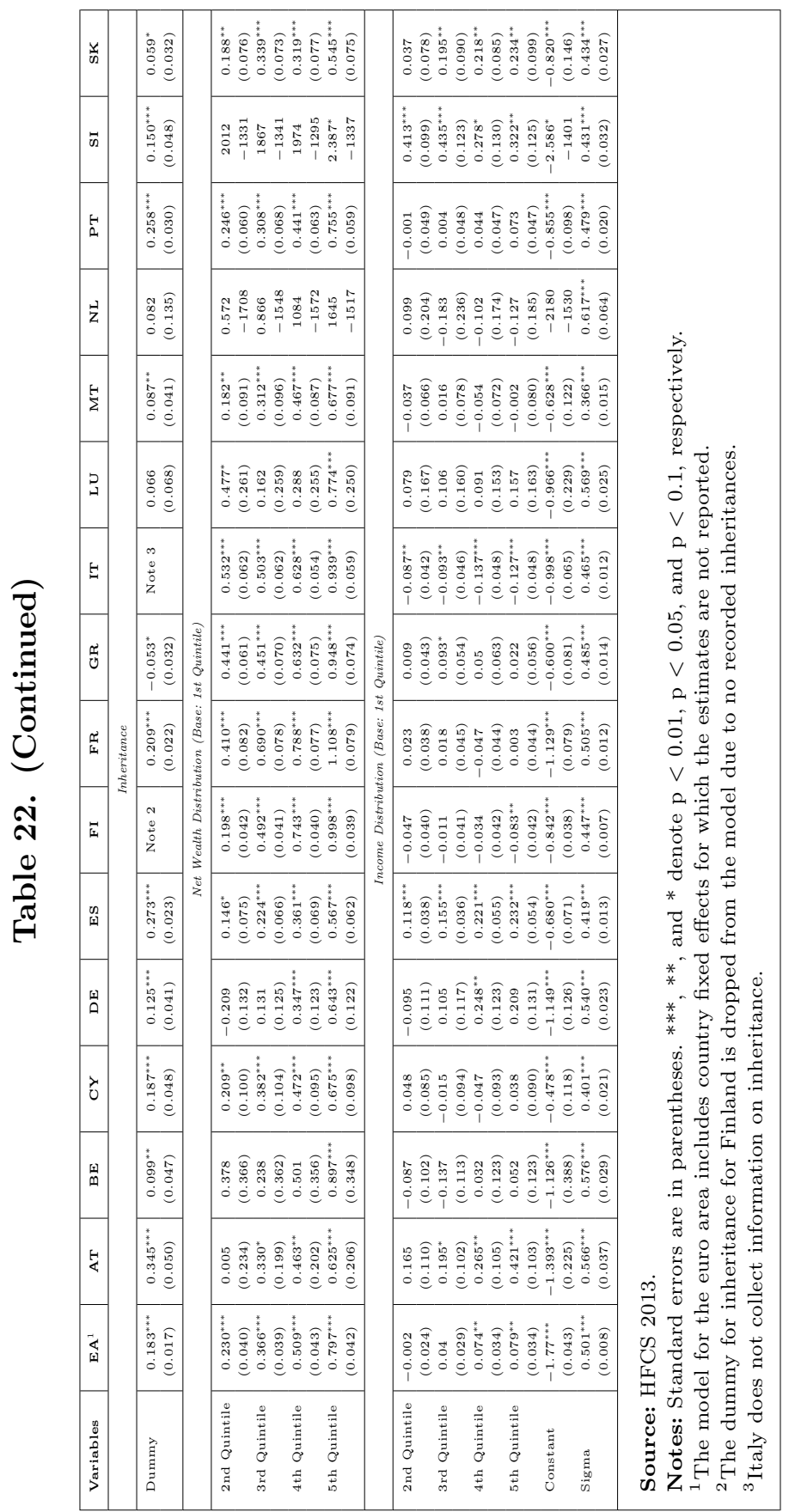




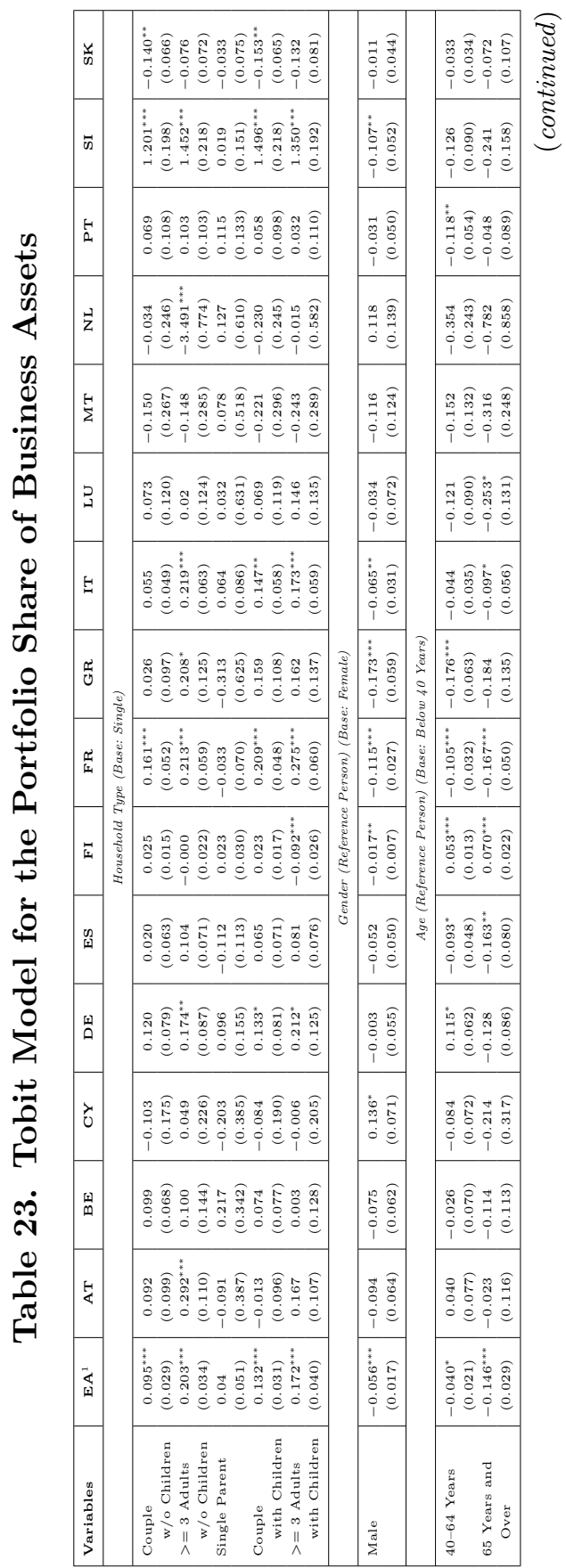




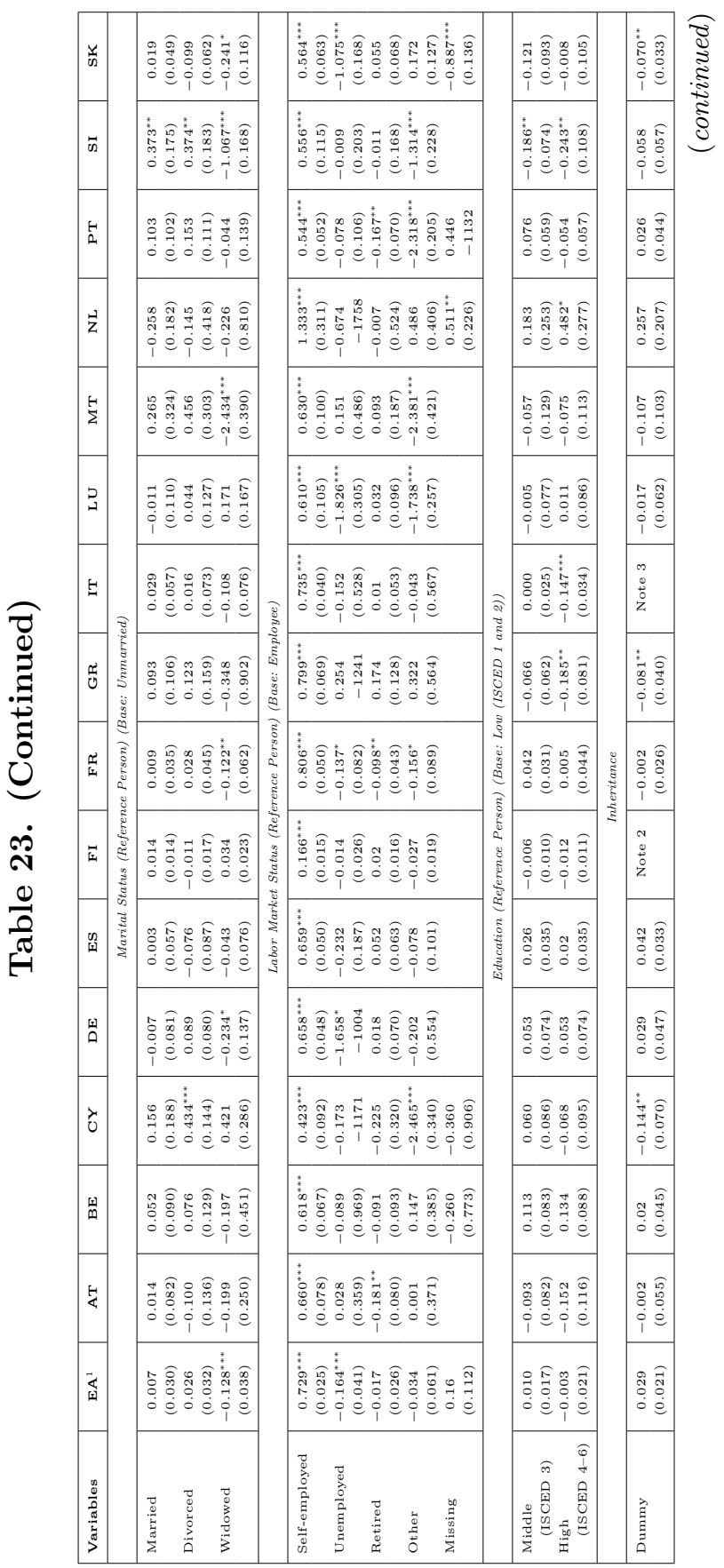




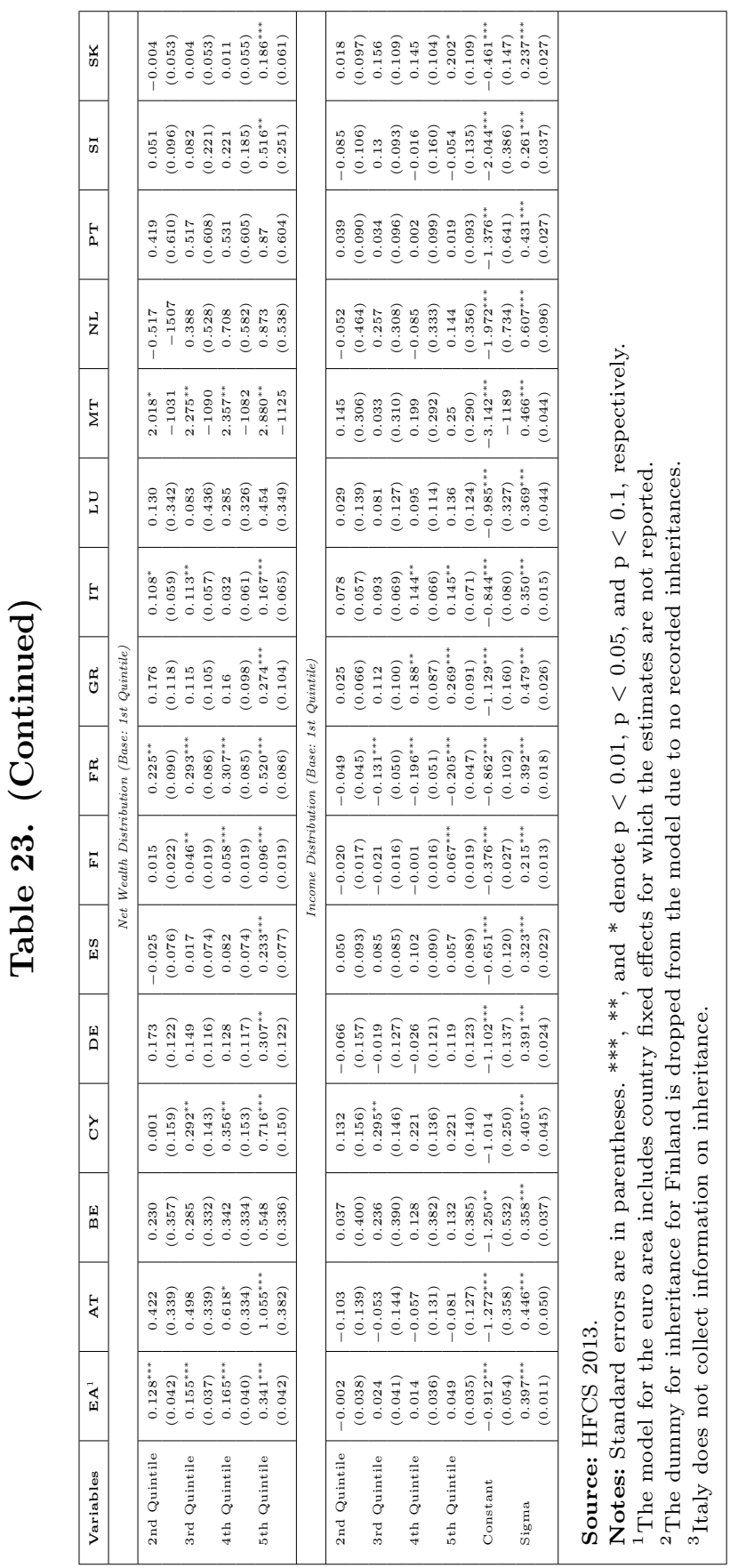




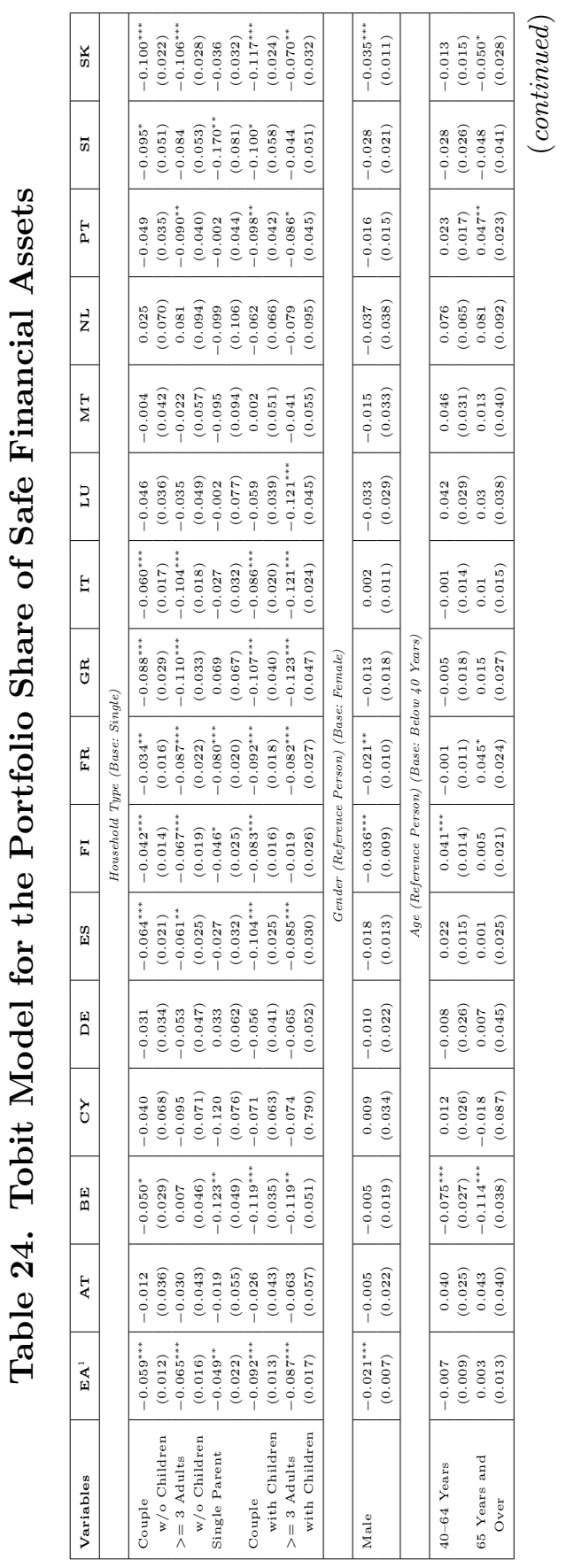




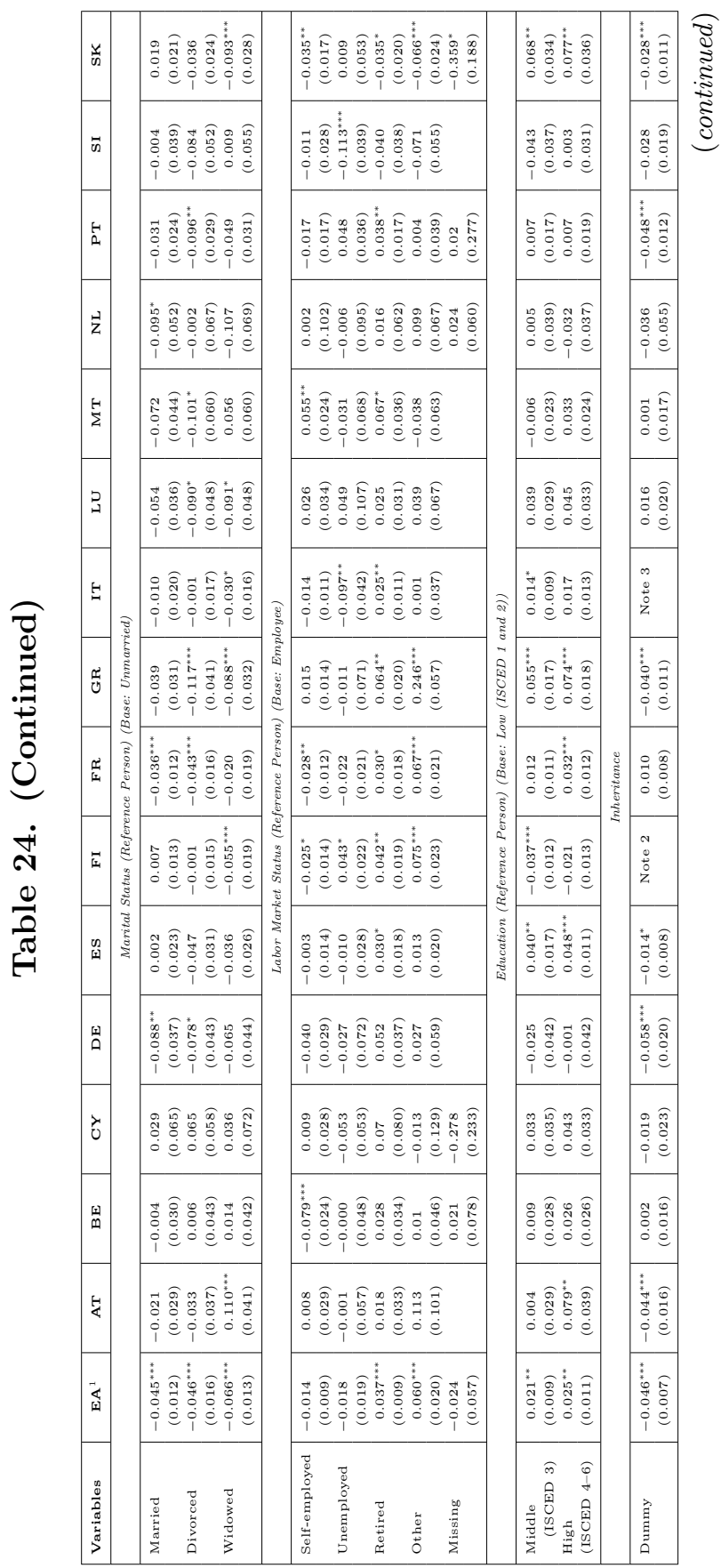




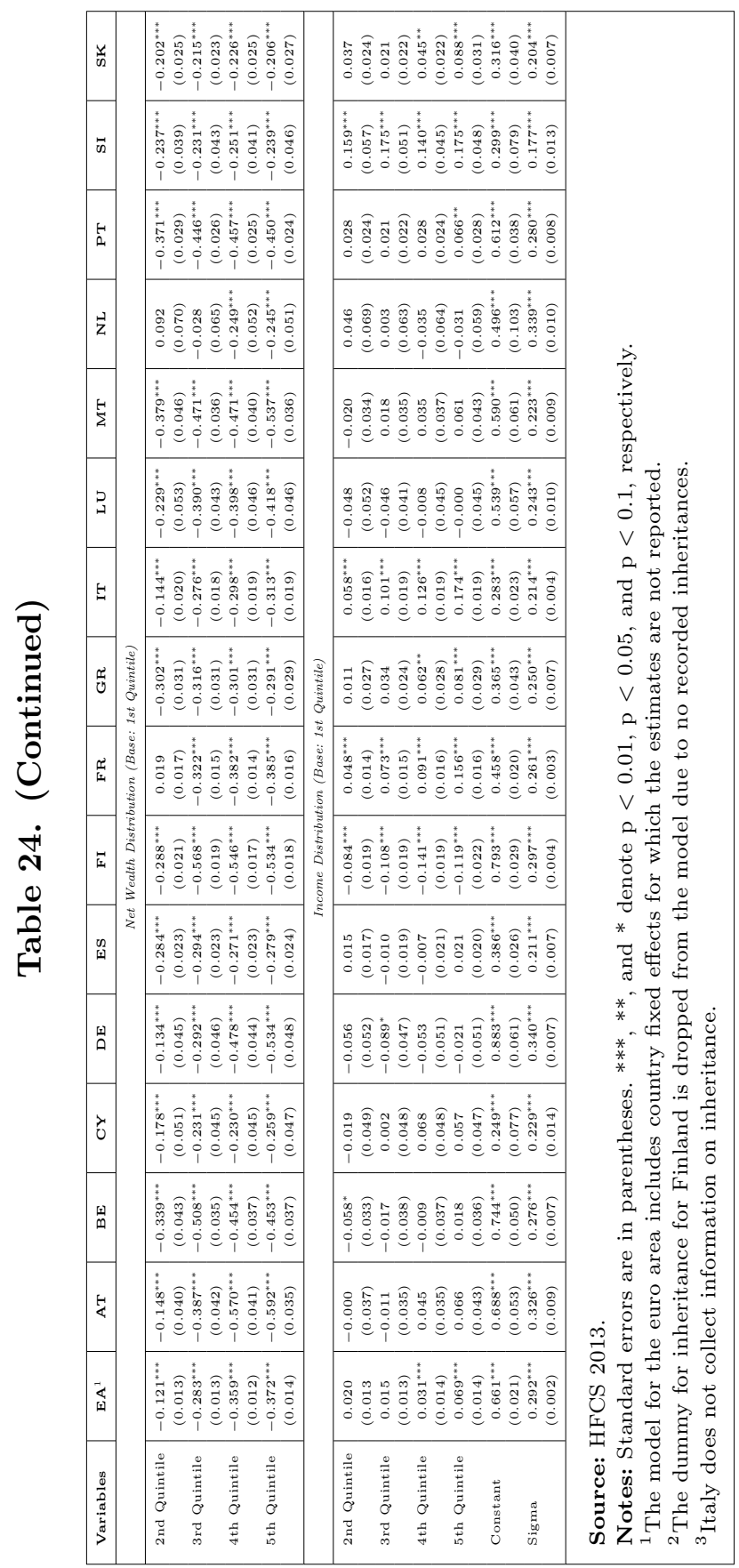




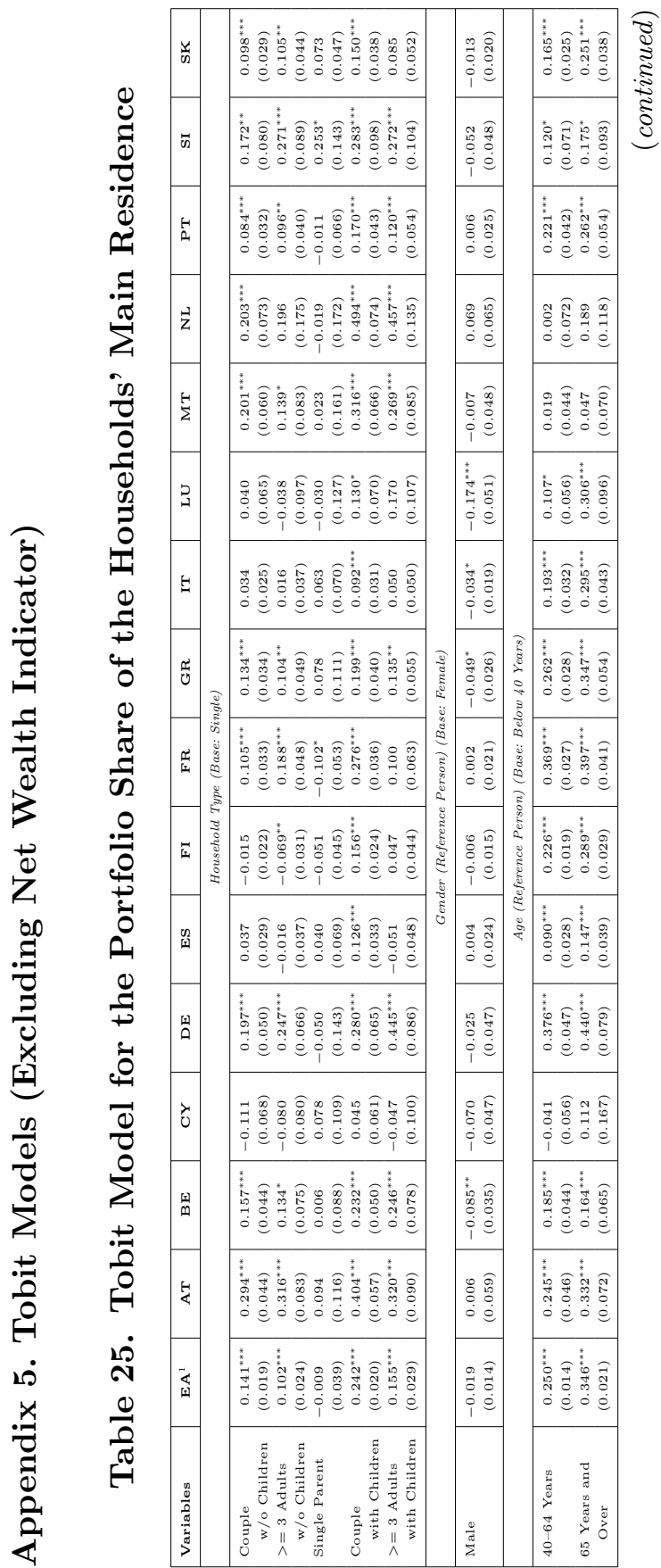


Vol. 12 No. 2

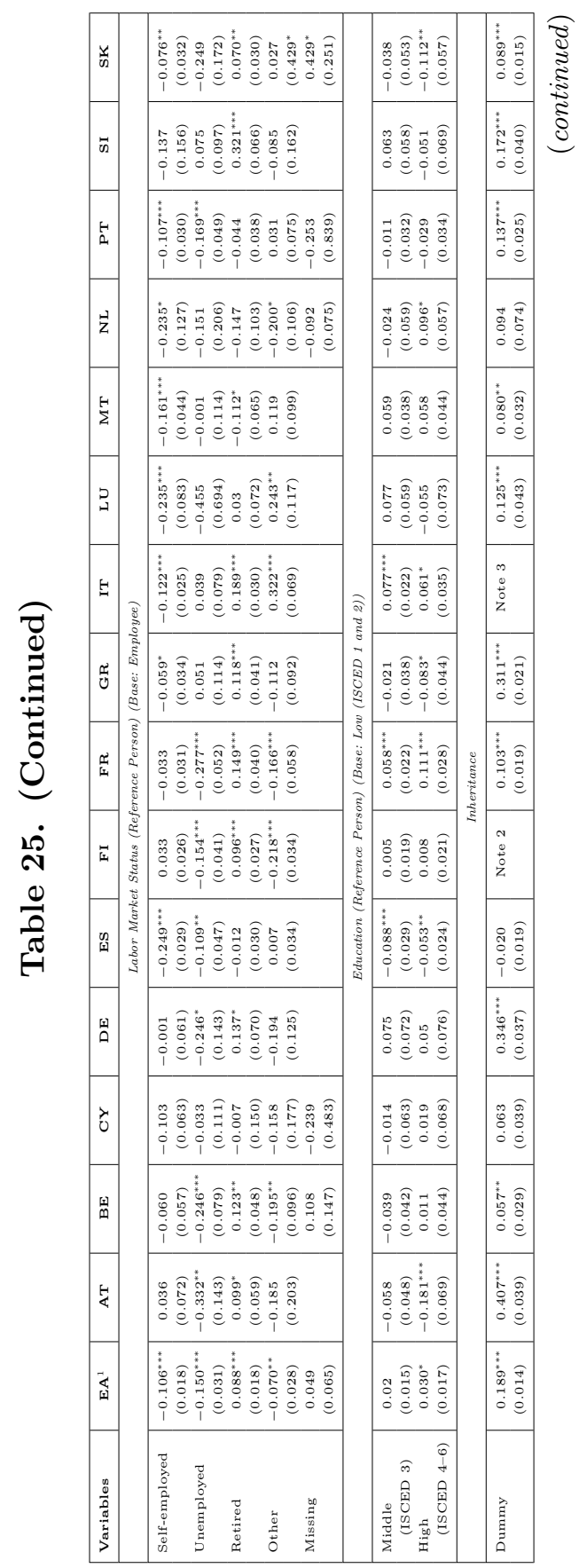




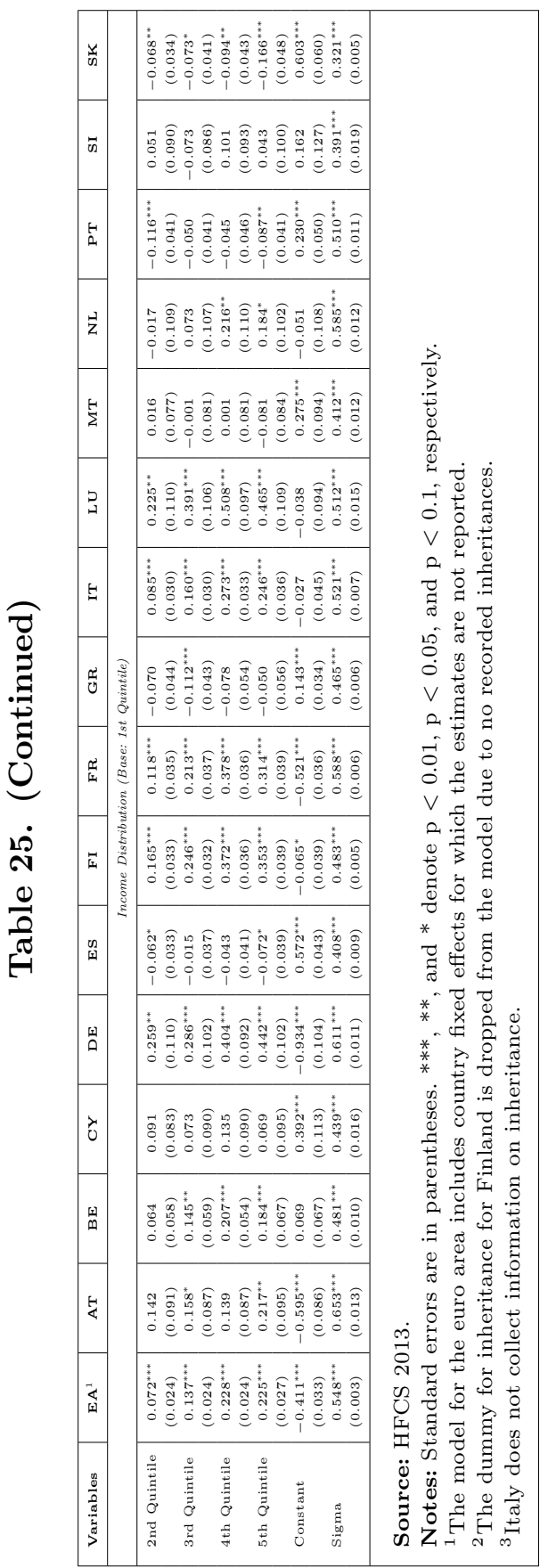




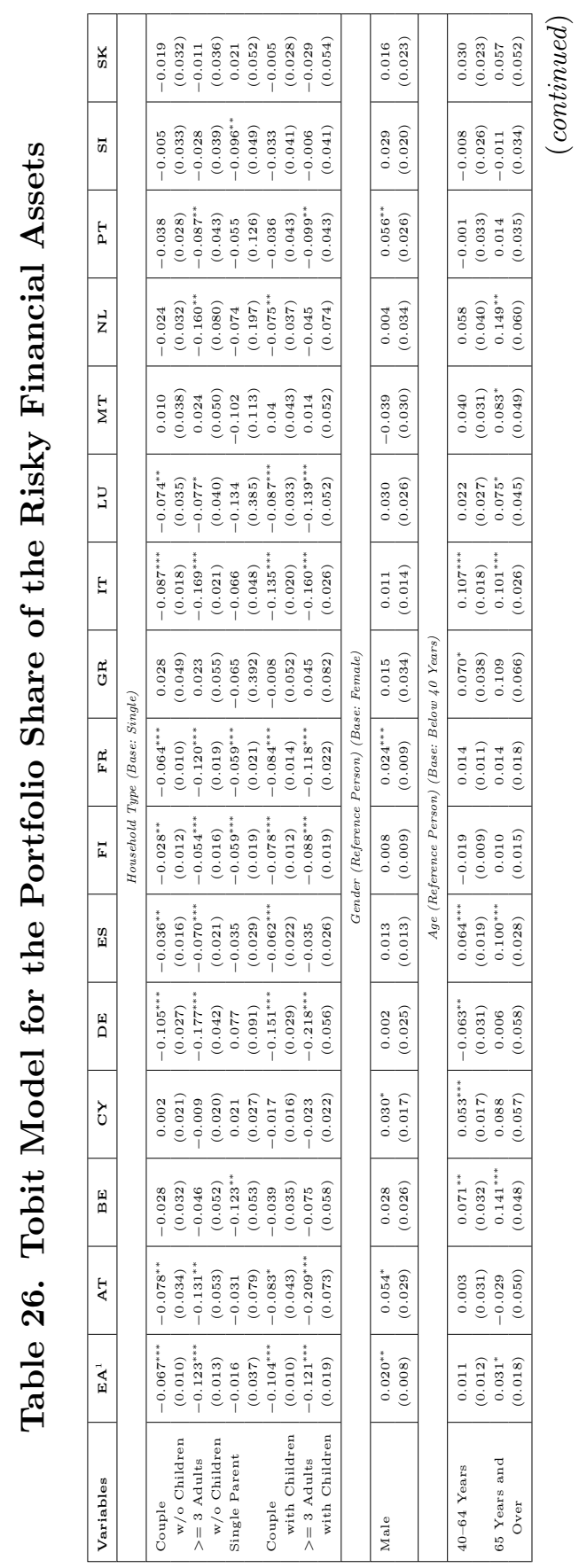




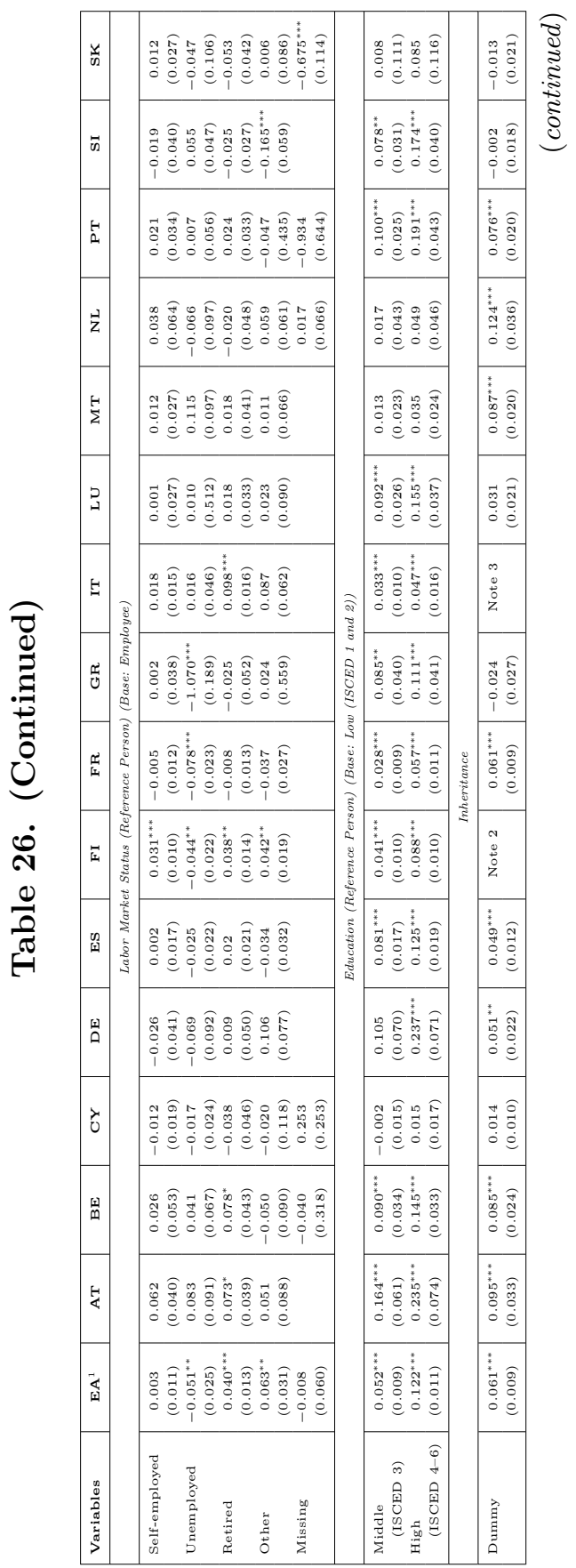


Vol. 12 No. 2

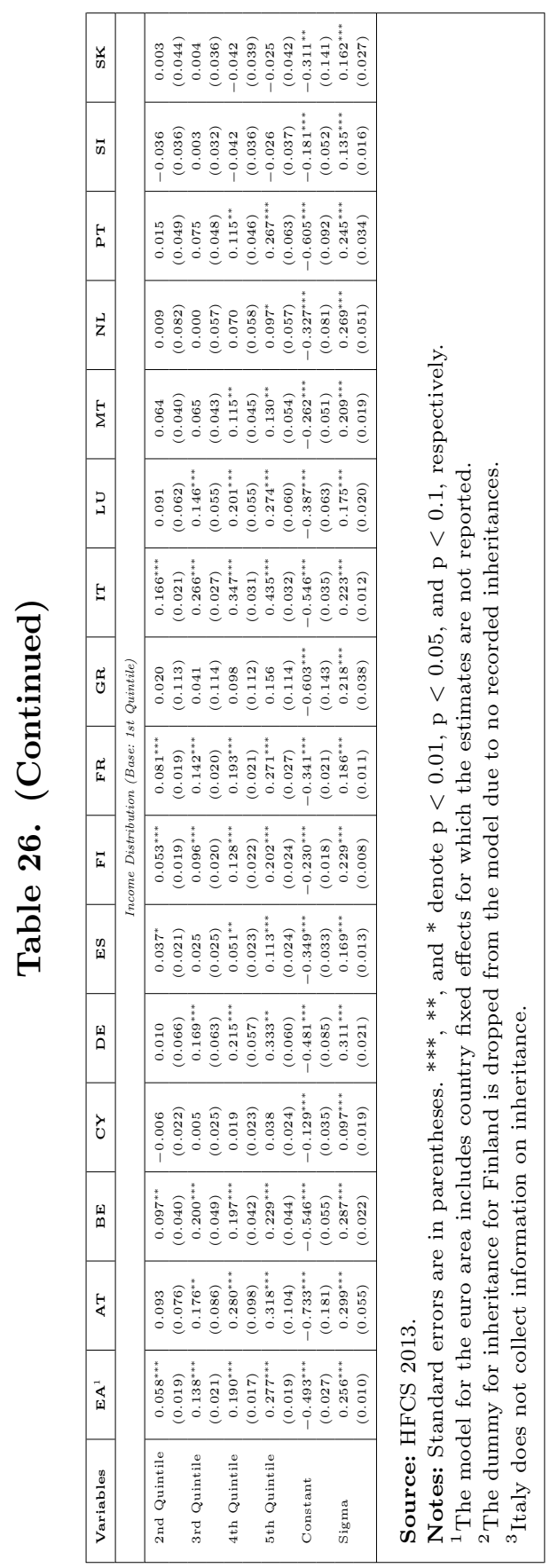




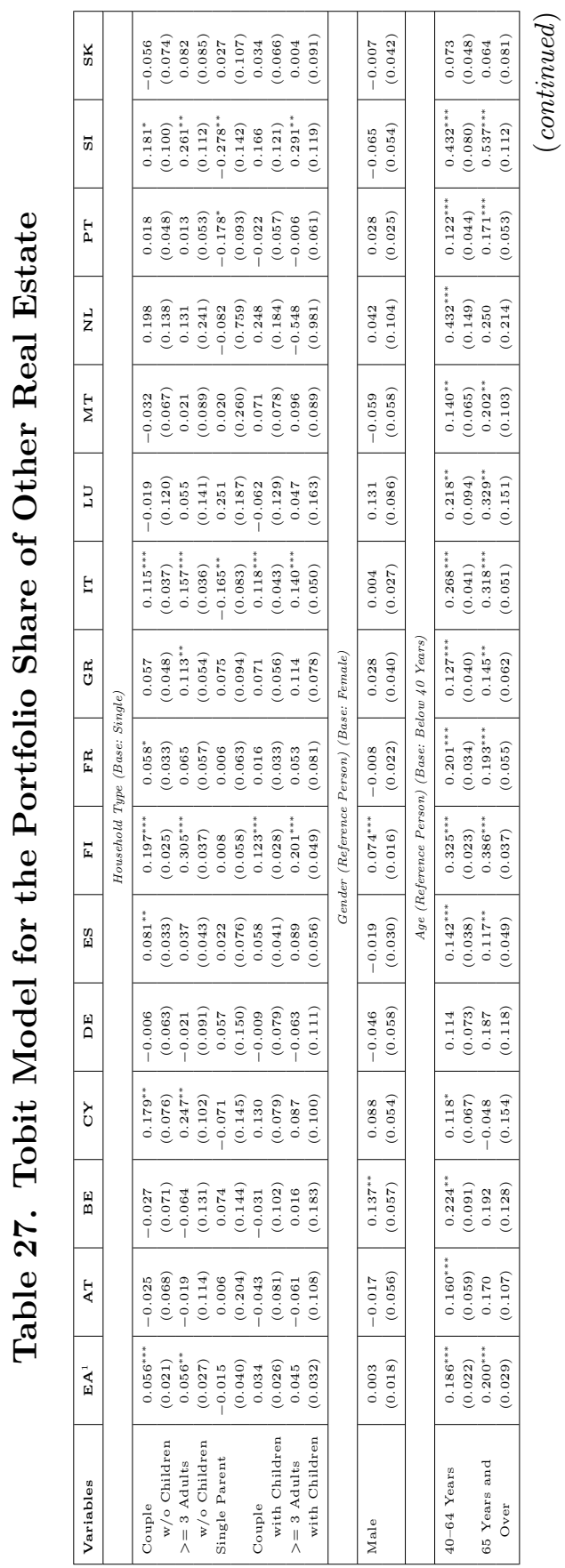


Vol. 12 No. 2

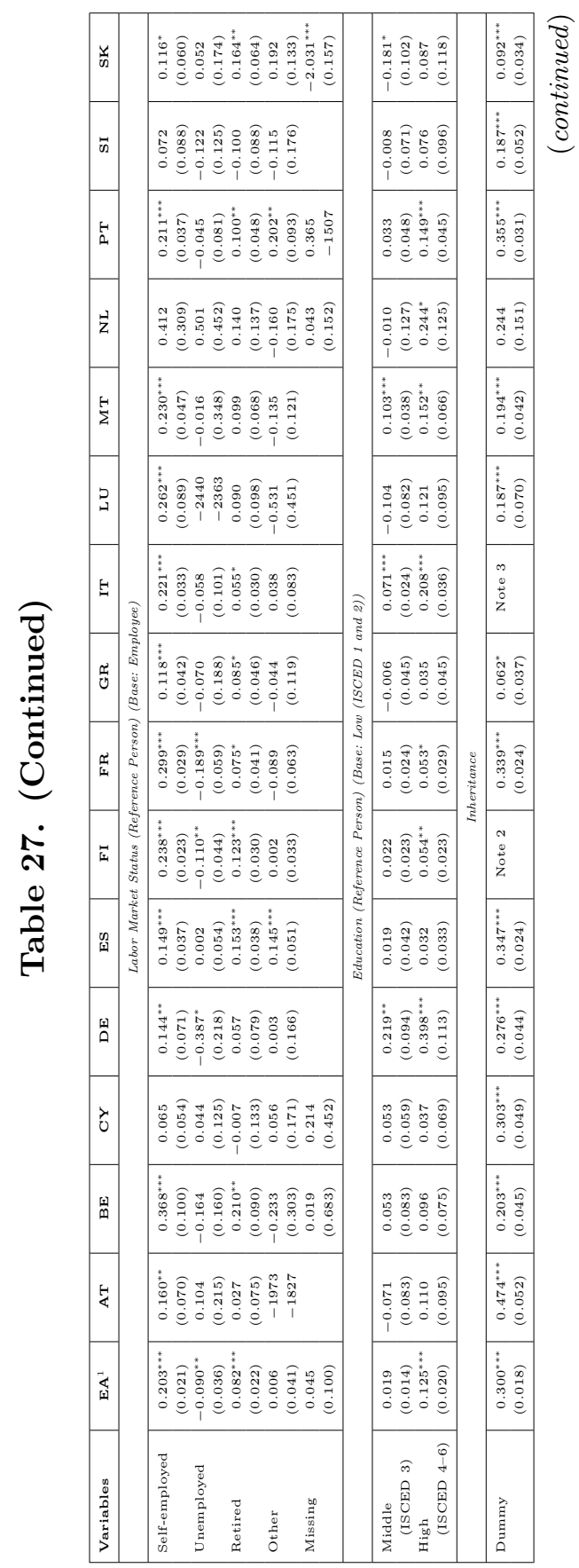




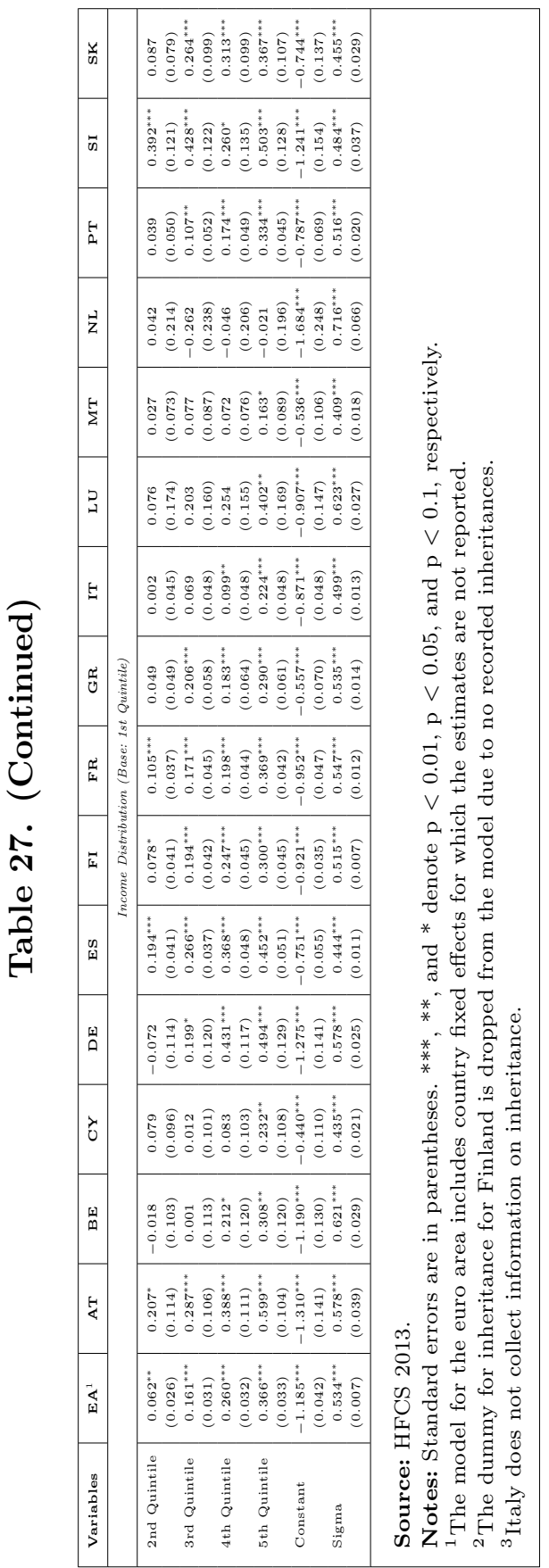




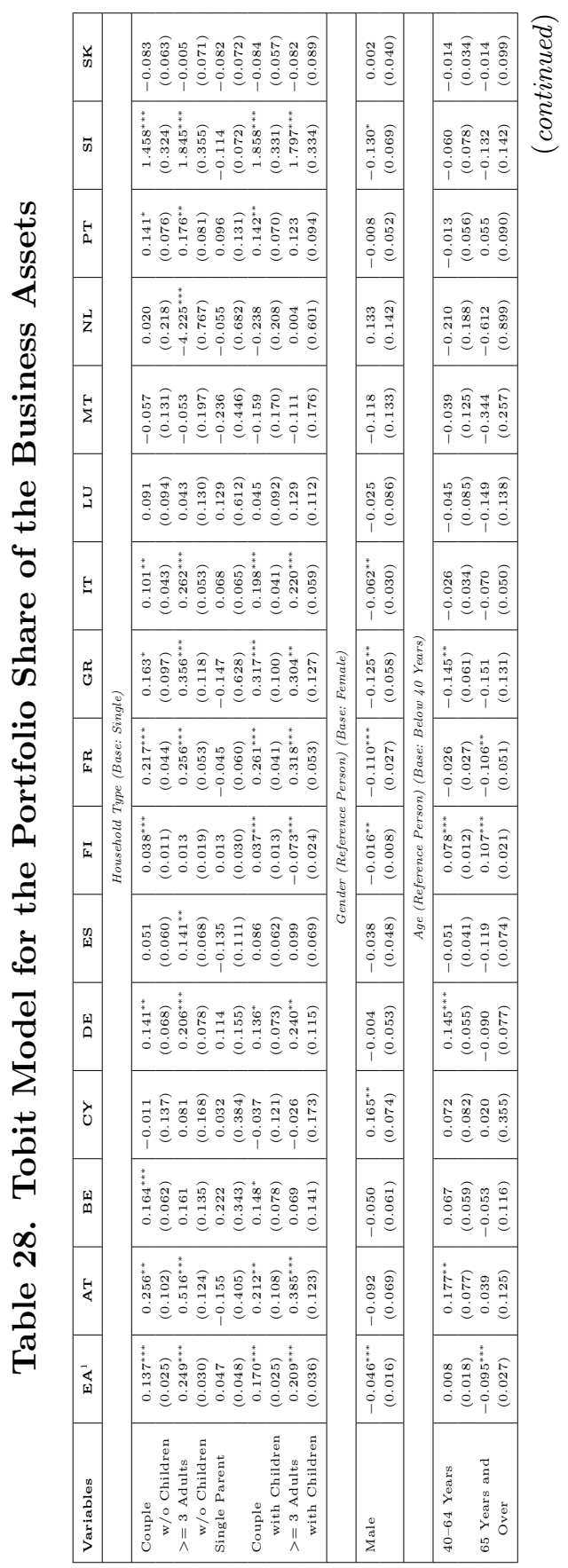




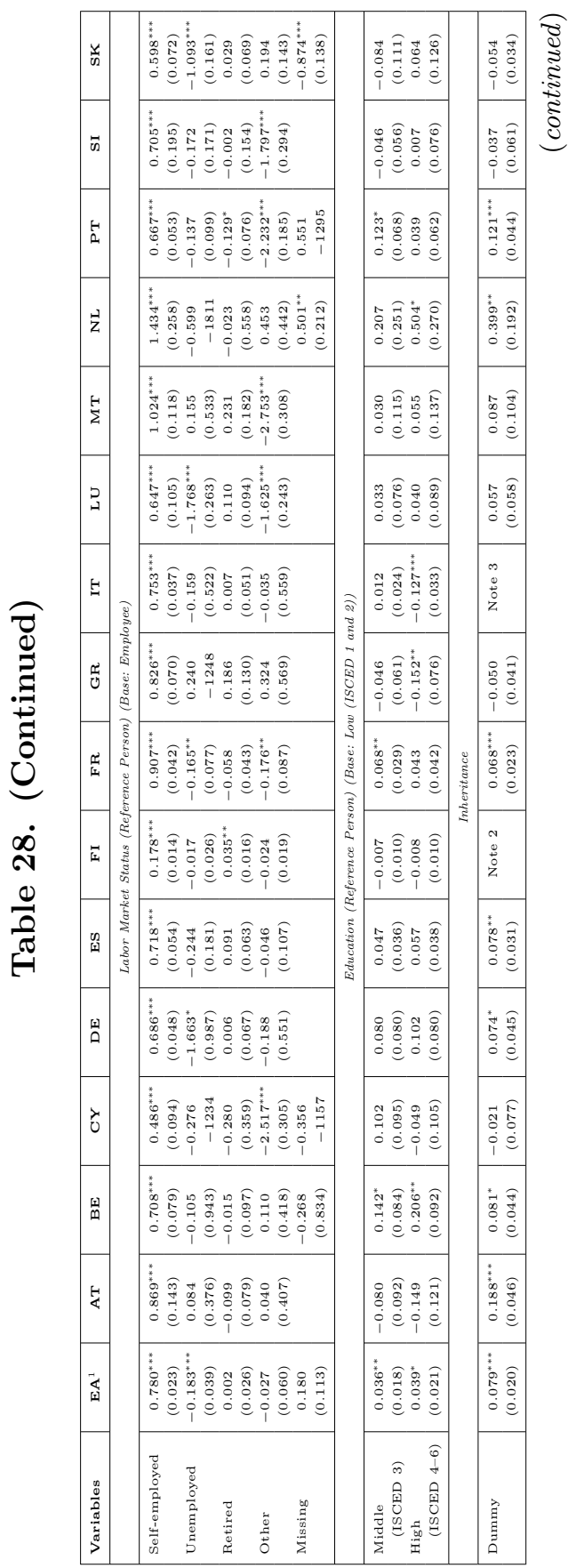


Vol. 12 No. 2

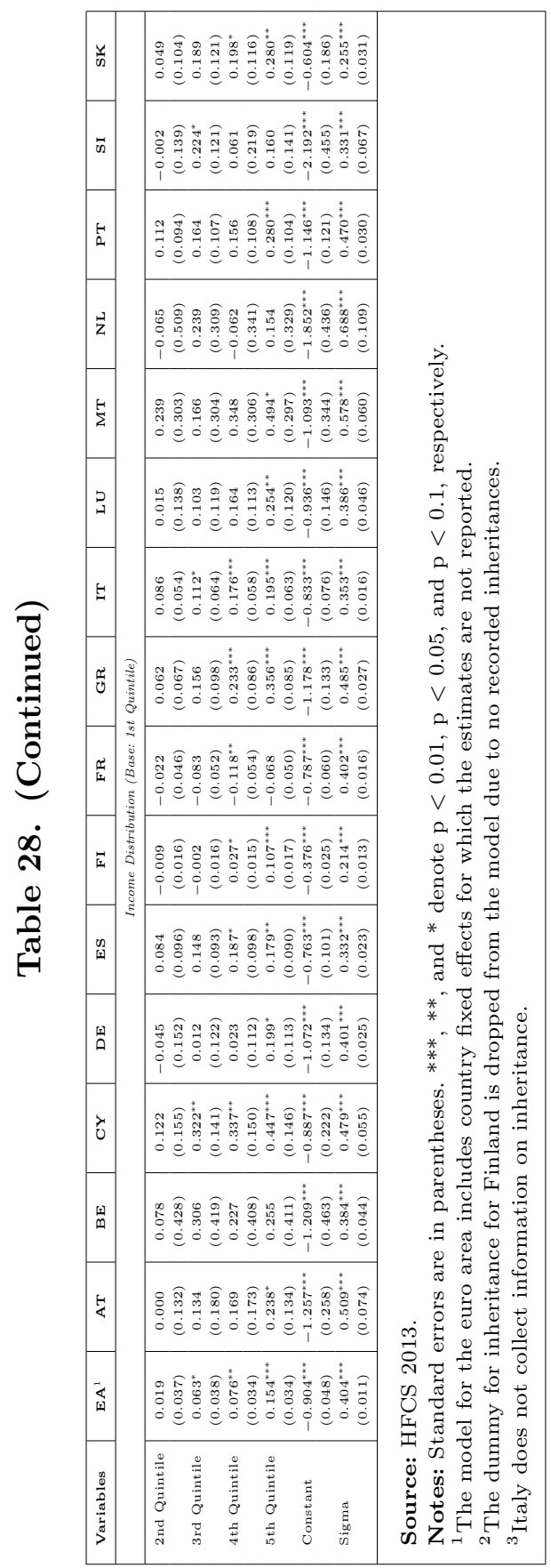




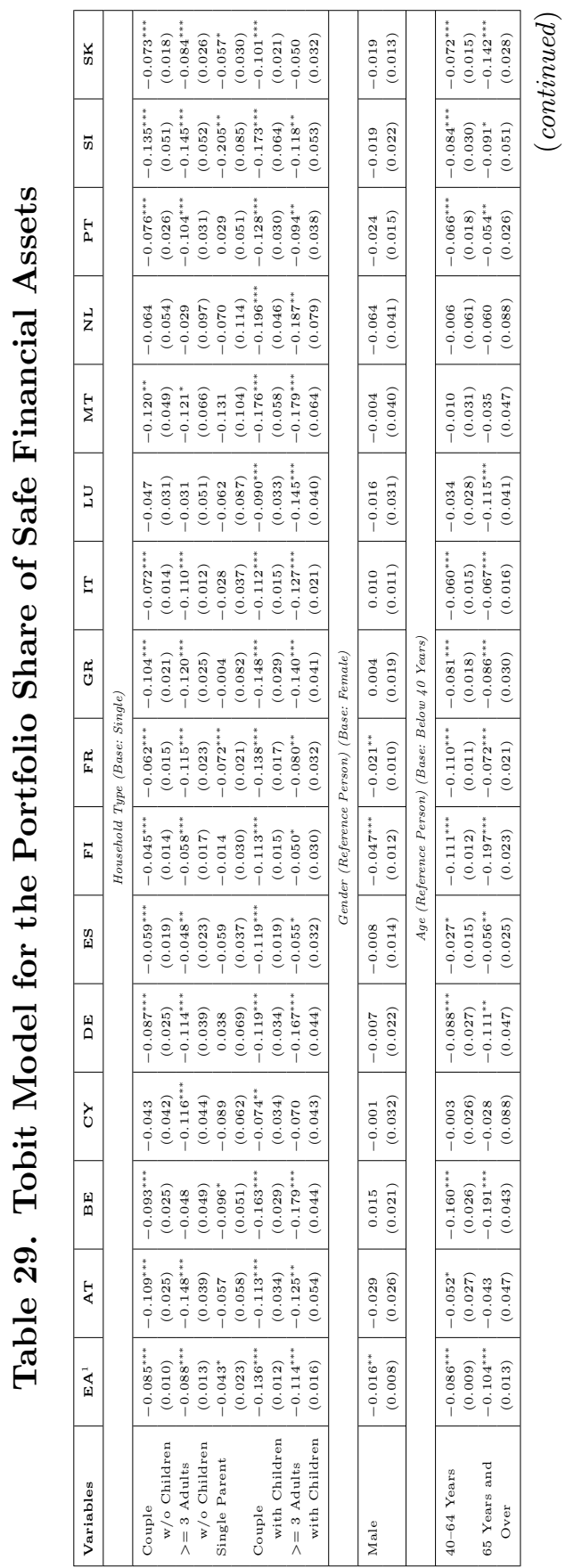


Vol. 12 No. 2

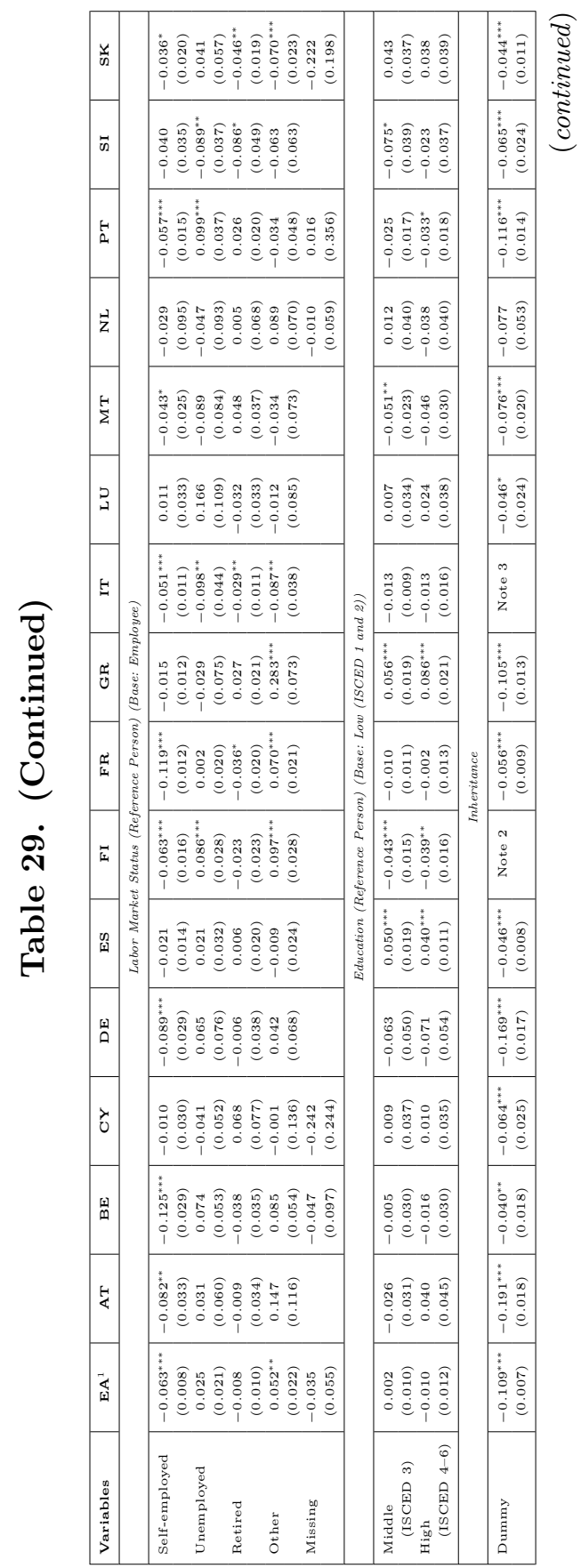




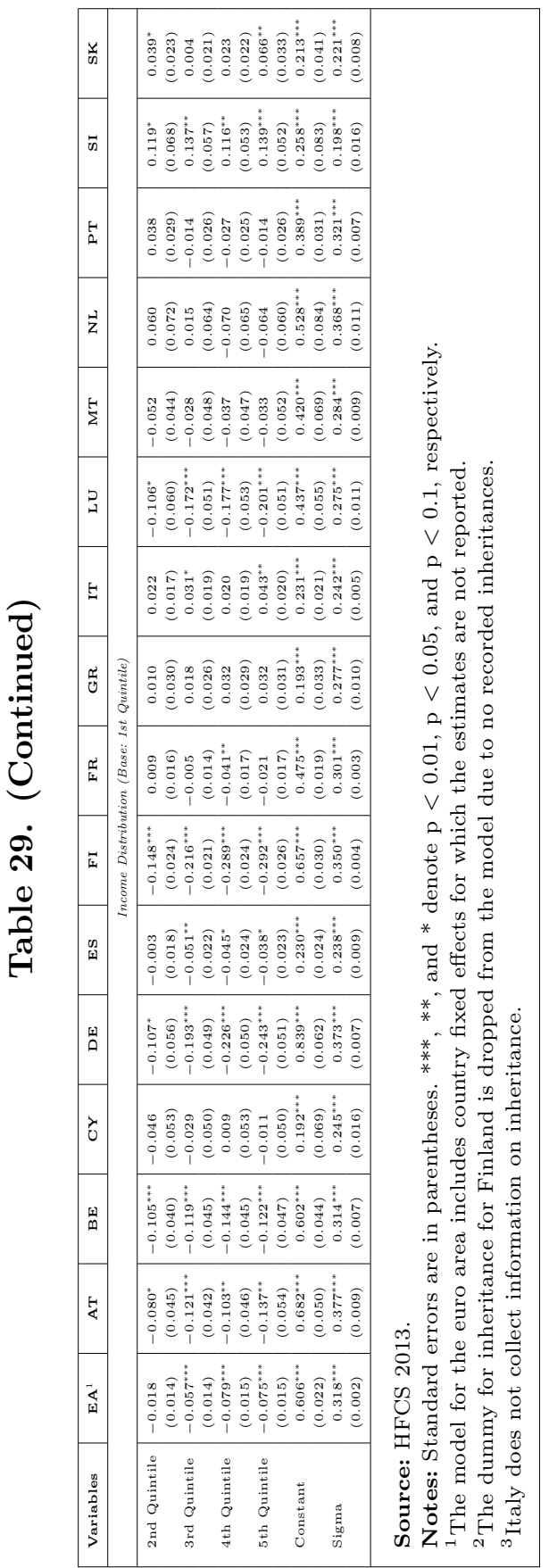




\section{Appendix 6. Definitions}

\section{Definition of Explanatory Variables}

- Household Type: single (base), couples with children, three or more adults without children, single parent, couple with dependent children, three or more adults with dependent children

- Gender of the Reference Person: dummy equal to 1 for male reference person

- Age of Reference Person: below forty years (base), forty to sixty-four years, sixty-five years and older

- Marital Status of the Reference Person: single (base), married (including consensual union on a legal basis), divorced, widowed

- Employment Status of the Reference Person: employee (base), self-employed, unemployed, retired, other, missing

- Education of the Reference Person: low (ISCED 1 and 2) (base), middle (ISCED 3), high (ISCED 4-6)

- Inheritance: dummy equal to 1 if a household has inherited in the past

- Net Wealth Distribution: quintiles (base: first quintile)

- Income Distribution: quintiles (base: first quintile)

\section{Definition of Reference Person}

- The reference person is defined in accordance with the Canberra definition, i.e., applying the following rule in the order that is given until one person is found: "one of the partners in a registered or de facto marriage, with dependent children; one of the partners in a registered or de facto marriage, without dependent children; a lone parent with dependent children; the person with the highest income; the eldest person" (see also United Nations 2011, pp. 65-66). 
Definitions of the Institutional Indicators

Table 30. Institutional Indicators-Investigating
Differences in the Effect of Explanatory Variables
for Housing Assets

\begin{tabular}{|c|c|c|}
\hline Indicators & Definition & Source \\
\hline Mortgage Market & $\begin{array}{l}\text { Share of mortgages used for } \\
\text { purposes other than financing a } \\
\text { new home }\end{array}$ & ECB (2009) \\
\hline $\begin{array}{l}\text { Housing } \\
\quad \text { Price-to-Rent Ratio }\end{array}$ & $\begin{array}{l}\text { Price of the house on annual rent; } \\
\text { long-term average }=100 ; 2009\end{array}$ & OECD Stat \\
\hline $\begin{array}{l}\text { Inheritance Tax on } \\
\text { HMR }\end{array}$ & $\begin{array}{l}\text { Yes/No-Inheritance tax on own } \\
\text { principal home }\end{array}$ & ECB (2009) \\
\hline $\begin{array}{l}\text { Pension-Replacement } \\
\text { Rate }\end{array}$ & $\begin{array}{l}\text { Gross pension-replacement rates: } \\
\text { average earners }\end{array}$ & OECD (2011) \\
\hline
\end{tabular}

Table 31. Institutional Indicators - Investigating Differences in the Effect of Explanatory Variables for Risky Assets

\begin{tabular}{|c|c|c|}
\hline Indicators & Definition & Source \\
\hline Stock Capitalization & $\begin{array}{l}\text { Stock market total value traded } \\
\text { to GDP }(\%)\end{array}$ & World Bank \\
\hline Literacy & $\begin{array}{l}\text { Senior business leader's } \\
\text { evaluation of the statement } \\
\text { "Economic literacy among } \\
\text { the population is generally } \\
\text { high-scale from } 0 \text { to } 10 "\end{array}$ & $\begin{array}{l}\text { "World } \\
\text { Competitiveness } \\
\text { Yearbook" as seen in } \\
\text { figure 1 (Jappelli } \\
\text { 2010) }\end{array}$ \\
\hline Trust & $\begin{array}{l}\text { Country index of interpersonal } \\
\text { trust (last available data } \\
1999 \text { for AT, BE, GR, LUX, } \\
\text { MT, PT, SK; } 2005 \text { for DE, } \\
\text { Fl, IT, SI; } 2006 \text { for CY, FR, } \\
\text { NL; } 2007 \text { for ES) }\end{array}$ & $\begin{array}{l}\text { Values Surveys } \\
\text { EVS/WVS }\end{array}$ \\
\hline Internet Access & $\begin{array}{l}\text { Percentage of households with } \\
\text { access to the Internet }(2009)\end{array}$ & OECD-EU Community \\
\hline $\begin{array}{l}\text { Pension-Replacement } \\
\text { Rate }\end{array}$ & $\begin{array}{l}\text { Gross pension-replacement } \\
\text { rates: average earners }\end{array}$ & OECD (2011) \\
\hline
\end{tabular}




\section{References}

Campbell, J. 2006. "Household Finance." Journal of Finance 61 (4): $1553-1604$.

Carroll, C. D. 2002. "Portfolios of the Rich." In Household Portfolios, ed. L. Guiso, M. Haliassos, and T. Jappelli, 389-429 (chapter 10). Cambridge, MA: MIT Press.

Chiuri, M. C., and T. Jappelli. 2003. "Financial Market Imperfections and Home Ownership: A Comparative Study." European Economic Review 47 (5): 857-75.

Christelis, D., D. Georgarakos, and M. Haliassos. 2013. "Differences in Portfolios across Countries: Economic Environment versus Household Characteristics." Review of Economics and Statistics 95 (1): 220-36.

Cox, C., and O. Stark. 2005. "Bequests, Inheritances and Family Traditions." Working Paper No. 2005-09, Center for Retirement Research.

Davies, J. B., and A. F. Shorrocks. 1999. "The Distribution of Wealth." In Handbook of Income Distribution, Vol. 1, ed. A. B. Atkinson and F. Bourguignon, 605-75 (chapter 11). Elsevier.

European Central Bank. 2009. "Housing Finance in the Euro Area." ECB Occasional Paper No. 101.

European Commission. 2011. "Study on the Costs and Benefits of the Different Policy Options for Mortgage Credit." Final Report. Guiso, L., M. Haliassos, and T. Jappelli. 2002. Household Portfolios. Cambridge, MA: MIT Press.

- 2003. "Household Stockholding in Europe: Where Do We Stand and Where Do We Go?" Economic Policy 18 (36): 123-70. Guiso, L., T. Jappelli, and D. Terlizzese. 1996. "Income Risk, Borrowing Constraints, and Portfolio Choice." American Economic Review 86 (1): 158-72.

Guiso, L., P. Sapienza, and L. Zingales. 2008. "Trusting the Stock Market." Journal of Finance 63 (6): 2557-2600.

Heaton, J., and D. Lucas. 2000. "Portfolio Choice in the Presence of Background Risk." Economic Journal 110 (460): 1-26.

Household Finance and Consumption Network (HFCN). 2013a. "The Eurosystem Household Finance and Consumption Survey: Methodological Report for the First Wave." ECB Statistical Paper No. 1. 
— 2013b. "The Eurosystem Household Finance and Consumption Survey: Results from the First Wave." ECB Statistical Paper No. 2.

Jappelli, T. 2010. "Financial Literacy: An International Comparison." Economic Journal 120 (548): F429-F451.

Mathä, T. Y., A. Porpiglia, and M. Ziegelmeyer. 2014. "Household Wealth in the Euro Area: The Importance of Intergenerational Transfers, Homeownership and House Price Dynamics." ECB Working Paper No. 1690.

Organisation for Economic Co-operation and Development (OECD). 2011. Pensions at a Glance 2011: Retirement-income Systems in OECD and G20 Countries. OECD Press.

Sierminska, E., and K. Doorley. 2012. "Decomposing Wealth Portfolios across Countries: An Age-Old Question?" LISER Working Paper No. 2012-32.

United Nations. 2011. Canberra Group Handbook on Household Income Statistics, $2^{\text {nd }}$ Edition. Geneva: United Nations.

Van Rooij, M., A. Lusardi, and R. Alessie. 2011. "Financial Literacy and Stock Market Participation." Journal of Financial Economics 101 (2): 449-72. 